EFFECTS OF AGRICULTURAL BEST-MANAGEMENT PRACTICES ON TOTAL PHOSPHORUS YIELDS IN THE JOHNSON BROOK AND LOVEJOY POND WATERSHEDS, KENNEBEC COUNTY, MAINE, 1980-84

By Thomas J. Maloney and John W. Sowles

U.S. GEOLOGICAL SURVEY

Water-Resources Investigations Report 87-4118

Prepared in cooperation with the MAINE DEPARTMENT OF ENVIRONMENTAL PROTECTION 
DEPARTMENT OF THE INTERIOR

DONALD PAUL HODEL, Secretary

U. S. GEOLOGICAL SURVEY

Dallas L. Peck, Director

For additional information, write to:

U.S. Geological Survey

26 Ganneston Drive

Augusta, ME 04330
Copies of this report can be purchased from:

U.S. Geological Survey Books and Open-File Reports Section Box 25425, Federal Center Building 41

Denver, CO 80225 


\section{CONTENTS}

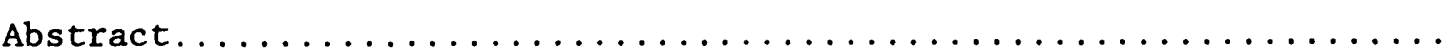

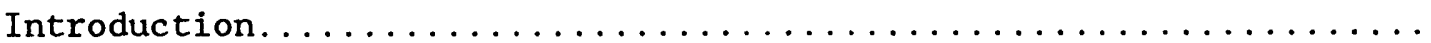

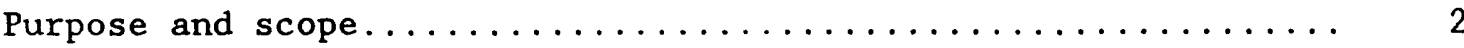

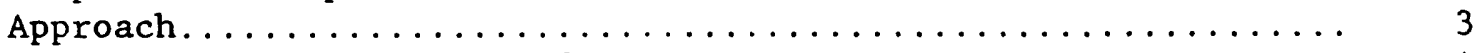

Location and description of study area................. 4

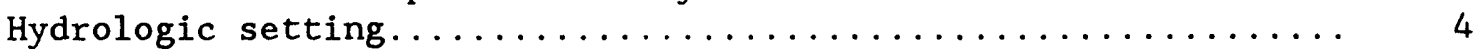

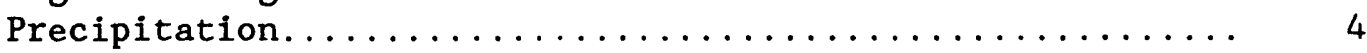

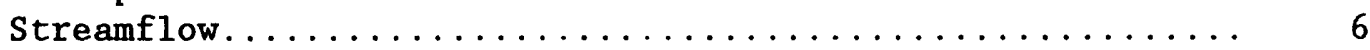

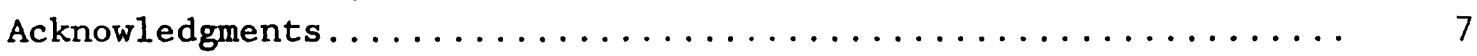

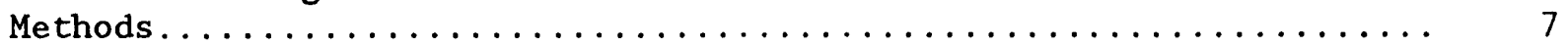

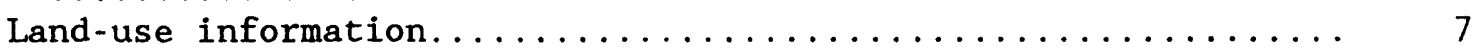

Hydrologic and water-quality data collection. .............. 10

Measurement of phosphorus yield..................... 11

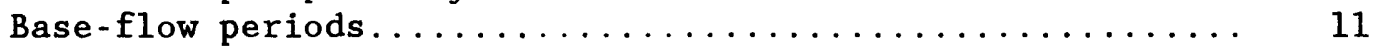

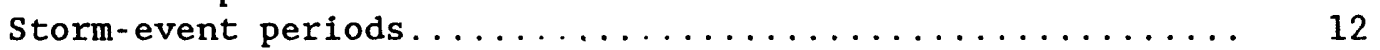

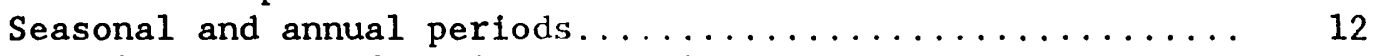

Statistical analysis of daily streamflow and

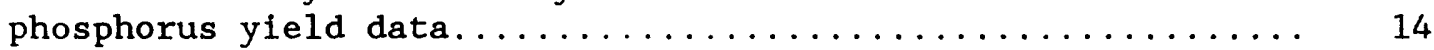

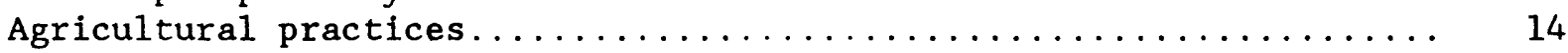

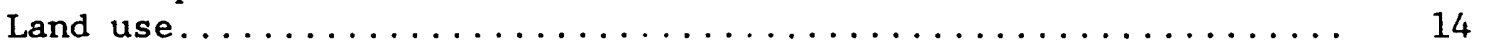

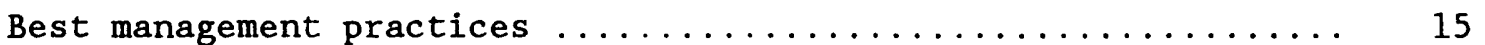

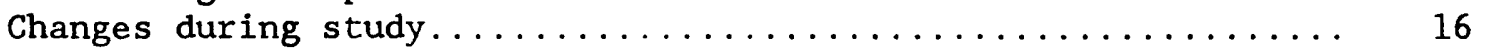

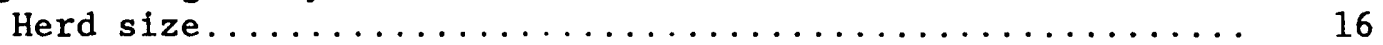

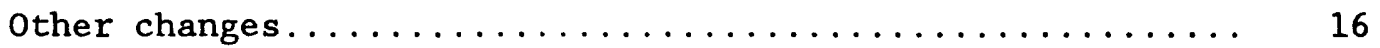

Effects of best-management practices on phosphorus yields........ 16

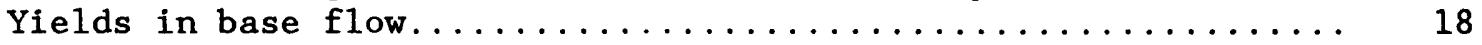

Yields from selected storms...................... 19

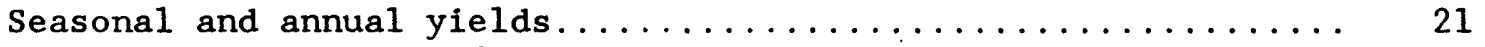

Statistical analysis of yields in selected

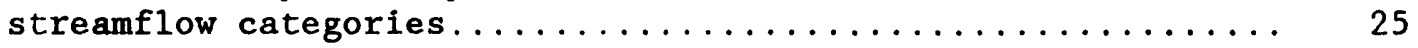

Effects of yields on eutrophication of Lovejoy Pond.......... 27

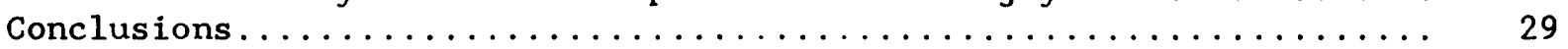

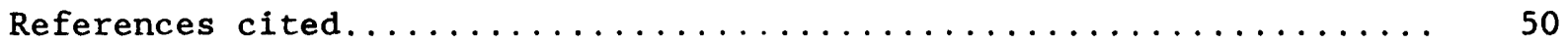




\section{ILLUSTRATIONS}

Figure 1. Map showing location of study area and data-collection

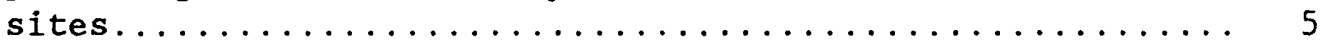

2. Subdivision technique used to compute daily storm loads..... 13

3. Agricultural 1and-use map..................... 17

4. Hydrographs comparing the February 2, 1981, preimplementation storm runoff event, the transition phase runoff event of March 2, 1983, and the postimplementation runoff event of January 27, 1986, for Johnson Brook at

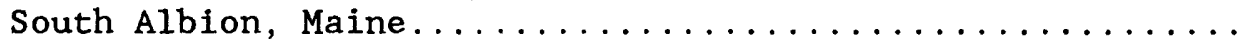

5. Hydrographs comparing the February 11, 1981 preimplementation storm runoff event with the postimplementation runoff event of February 15, 1984, for Johnson Brook at

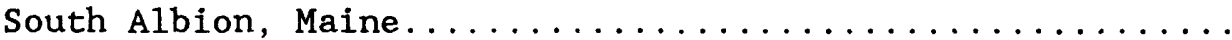

6. Graph showing total annual discharge, total annual phosphorus yield, and total phosphorus yield per 100 animals for Johnson Brook at South Albion, Maine,

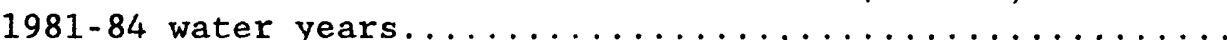

7. Boxplots of preimplementation and postimplementation phosphorus yields for selected streamflow categories.....

\section{TABLES}

Table 1. Distribution of storm events, storms sampled, and totalphosphorus samples analyzed for the best-managementpractice implementation phases in the Johnson Brook

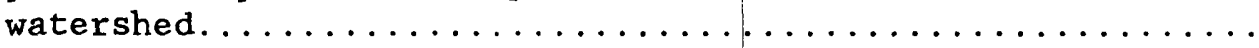

2. Summary of precipitation data from National Weather Service Station at Waterville Pumping Station, Waterville, Maine,

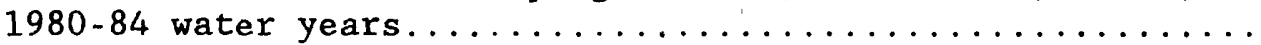

3. Streamflow data for Johnson Brook at South Albion, Maine,

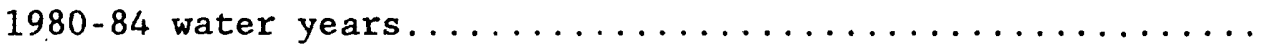

4. Summary of monthly and annual streamflow statistics from Johnson Brook at South Albion, Maine, 1980-84 water years... and use in the Johnson Brook study area after implementation

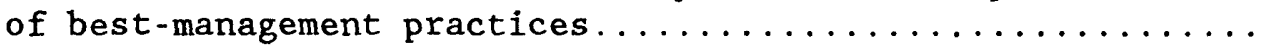

6. Water-quality data from Johnson Brook at South Albion, Maine,

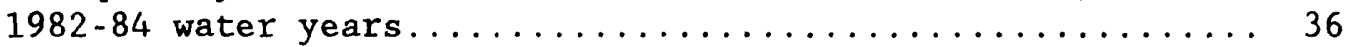

7. Phosphorus yields from Johnson Brook at South Albion, Maine,

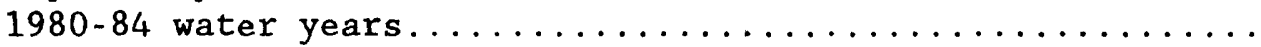

8. Summary of discharge totals, total phosphorus-yield, herd size, and adjusted total phosphorus yield per 100 animals for Johnson Brook at South Albion, Maine, summer 1980

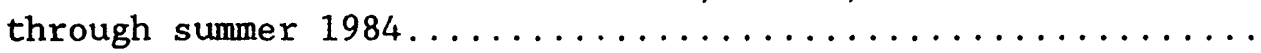

9. Comparison of preimplementation and postimplementation daily phosphorus yields within selected streamflow categories..... 
For the convenience of readers who may prefer to use inch-pound units rather than the metric (International system) units used in this report, values may be converted by using the following factors:

\section{Length}

$\begin{array}{lll}\text { millimeter }(\mathrm{mm}) & 0.03937 & \text { inch (in.) } \\ \text { meter }(\mathrm{m}) & 3.281 & \text { foot (ft) } \\ \text { kilometer }(\mathrm{km}) & 0.6214 & \text { mile (mi) }\end{array}$

\section{Area}

hectare

square kilometer $\left(\mathrm{km}^{2}\right)$

cubic meter per second

$\left(\mathrm{m}^{3} / \mathrm{s}\right)$

$\operatorname{gram}(g)$
2.471

0.3861

\section{Flow}

35.31

cubic foot per second $(\mathrm{ft} / \mathrm{s})$

Mass

0.002205

pound (1b)

Temperatures given in degrees Celsius $\left({ }^{\circ} \mathrm{C}\right)$ can be converted to degrees Fahrenheit by the equation: ${ }^{\circ} \mathrm{F}=1.8^{\circ} \mathrm{C}+32$. 


\title{
EFFECTS OF AGRICULTURAL BEST-MANAGEMENT PRACTICES ON TOTAL PHOSPHORUS YIELDS IN THE JOHNSON BROOK AND LOVEJOY POND WATERSHEDS, KENNEBEC COUNTY, MAINE, 1980-84
}

\author{
By Thomas J. Maloney and John W. Sowles ${ }^{2}$
}

\begin{abstract}
Analysis of daily phosphorus-yield and streamflow data collected before and after implementation of agricultural best-management practices in the Johnson Brook watershed in south-central Maine indicated statistically significant reductions in phosphorus loading in all flow categories. Reduction of median loadings for five flow categories ranged from 26 to 90 percent.

The annual total phosphorus yield was reduced 17 percent after implementation of the best-management practices. The observed phosphorus yield reduction is considerable because of two streamflow factors. First, the period after implementation of the best-management practices had eight more storms. Periods of storm runoff in the postimplementation period had 31 days with greater average streamflow and a maximum daily streamflow more than three times greater than those observed in the preimplementation period. Second, the annual streamflow was 128 percent greater in the year after the management practices were implemented. Because the potential for phosphorous transport increases with runoff, and greater yields are possible when the volume of water increases, a higher phosphorous yield would be expected in the postimplementation period then during the preimplementation period, if other factors had remained unchanged.

The reductions in phosphorous yield in the study area are not expected to have a significant effect on the eutrophic conditions observed in Lovejoy Pond. Phosphorous concentrations in the pond will continue to be capable of supporting algal blooms. However, the intensity and duration of blooms are expected to be less than those observed before best-management practice implementation.
\end{abstract}

1 Hydrologist, U.S. Geological Survey, Augusta, Maine

2 Biologist, Maine Department of Environmental Protection, Augusta, Maine 


\section{INTRODUCTION}

Eutrophication of lakes and ponds in central Maine is a major waterquality problem. Lovejoy Pond, in Albion, Maine, is an example of a water body that has undergone significant eutrophication. Blue-green algal blooms persist throughout the summer. The Maine Department of Environmental Protection (MDEP) identified nutrient loadings, primarily phosphorus, in runoff from dairy farms as the cause of the increased lake fertility (Sowles and Dominie, 1984). Consequently, the Kennebec County Soil and Water Conservation District developed agricultural BMP (best-management practice) plans for 22 farms in the Lovejoy Pond watershed. The farm-management plans focused on manure-spreading practices, cropland design, and access of dairy herds to surface water.

In-pond restoration activities such as nutrient inactivation or withdrawal of phosphorus-laden pond water were considered as steps to abate eutrophic conditions in Lovejoy Pond. In order to consider restoration activities in the pond, the effectiveness of the BMP plans to reduce phosphorus loading and prevent future pond degradation needed to be assessed. However, little information is available to document the effectiveness of agricultural BMPs on water quality in the northeastern United States. Studies in other areas of the country generally represent environmental conditions unlike those found in northern New England. Maine has a growing season that is typically less than 140 days. Precipitation of about 1,000 millimeters per year is twice the rate of evapotranspiration. High runoff-rainfall ratios have the potential for rapidly transporting nutrients, especially during the winter months when the ground is frozen.

In 1980, the U.S. Geological Survey and Maine Department of Environmental Protection began a cooperative investigation of phosphorous loading in the basin. The opportunity to collect data for an extended period prior to implementation of the BMP plans was an important factor which prompted this investigation. Another factor was that the Lovejoy Pond basin is typical of many other dairy-farming watersheds in central Maine and the results of this investigation should have transfer value to these other basins.

\section{Purpose and Scope}

This report presents the results of a study to determine the effectiveness of implementing BMP's on reducing phosphorus yields from the Johnson Brook watershed and in alleviating eutrophic conditions in Lovejoy Pond.

Interpretations in this report are based on data collected from March 1980 through September 1984. However, data for one storm during January 1986 also was analyzed to verify loading changes observed during the winter. Samples were collected during 90 of the 97 storms that occurred. Of the seven storms missed, only one was considered to be an important loading event. The peak runoff for the other six storms remained in the lower quartile of streamflows observed at the site. During the course of study, 1,378 samples were analyzed for total-phosphorus concentrations. The majority of these samples were collected during storm-runoff periods. Discussions of the effects of variations in streamflow and herdsize on the results of this study also are included. 


\section{Approach}

Concentrations of total phosphorus in Johnson Brook, the major tributary to Lovejoy Pond, were determined for a period of about four years. Collection of data began in March 1980, a ful1 year before implementation of the new farm-management practices, and continued until September 1984, one year after all practices were implemented. Storm runoff during January 1986 also was sampled to provide additional comparison information. For comparison purposes, the study period has been split into three discrete phases based on BMP implementation and herdsize differences. These phases are:

1) Preimplementation - prior to September 1981;

2) Transition - October 1981 to September 1983;

3) Postimplementation - October 1983 and after.

Table 1 provides the distribution of runoff events, runoff events sampled and total phosphorus concentration analyses for the three periods of the study. The effectiveness of the BMPs was analyzed by comparing phosphorous concentrations and yields before and after implementation.

Table 1.--Distribution of storm events, storms sampled, and totalphosphorus samples analyzed for best-management-practice implementation phases in the Johnson Brook watershed

\begin{tabular}{lcccc}
\hline & $\begin{array}{l}\text { Pre- } \\
\text { implemen- } \\
\text { tation }\end{array}$ & Transition & $\begin{array}{c}\text { Post- } \\
\text { implemen- } \\
\text { tation }\end{array}$ & Total \\
\hline $\begin{array}{l}\text { Number of } \\
\text { storm events }\end{array}$ & 25 & 39 & 33 & 97 \\
$\begin{array}{l}\text { Number of } \\
\text { storms sampled }\end{array}$ & 21 & 38 & 31 & 90 \\
$\begin{array}{l}\text { Number of } \\
\text { samples }\end{array}$ & 358 & 657 & 363 & 1,378 \\
\end{tabular}

Impacts of BMPs on the eutrophic conditions in Lovejoy Pond were estimated from the phosphorus yield changes observed in the Johnson Brook study area. Extrapolation of the study results to the entire Lovejoy Pond watershed was deemed valid, since Johnson Brook is representative of the hydrologic and agricultural characteristics of the entire basin and BMPs were concurrently implemented throughout the Lovejoy Pond watershed. 


\section{Location and Description of Study Area}

The Johnson Brook study area (figure 1) comprises $7.56 \mathrm{~km}^{2}$ of the Johnson Brook drainage in Kennebec County, south-central Maine. Danforth Road, about $0.8 \mathrm{~km}$ southeast of South Albion, marks the downstream end of the study area. Dutton Pond, $1.4 \mathrm{~km}$ upstream of Danforth Road, drains the headwater part of Johnson Brook. It has a $5.54 \mathrm{~km}^{2}$ watershed and a surface area of 22 hectares. The brook flows northward and is the major tributary stream of the $29.3 \mathrm{~km}^{2}$ Lovejoy Pond watershed.

The study area is in the New England Upland Physiographic Province (Fenneman, 1938) and is characterized by moderately sloping, rolling topography. Elevations in the Johnson Brook watershed range from about 75 meters at Danforth Road to about 160 meters on the southern basin boundary. Bedrock in the area is overlain by till in uplands and marine deposits of silt and clay in lowlands.

Land use in the study area is 19 percent agricultural, 78 percent forested, and 3 percent open water (the area of Dutton Pond). Agricultural areas in the drainage basin are primarily dairy farms with crop production limited to hay, alfalfa, corn, small grains, and pasturage.

\section{Hydrologic Setting}

Precipitation

A summary of precipitation data recorded at the Waterville Pumping Station is presented in table 2. Seasonal extremes ranged from as little as $130 \mathrm{~mm}$ in the winter of 1981 to as much as $510 \mathrm{~mm}$ in the spring of 1984 . Spring was the season with the most precipitation and winter the season with the least.

The long-term mean annual precipitation recorded at the Waterville Pumping Station is $1050 \mathrm{~mm}$ (Augusta Sardinha, National Oceanic and Atmospheric Administration, oral commun., 1985). The total precipitation during the 1981 water year was $944 \mathrm{~mm}$, or about 90 percent of normal. The 12 -month period beginning October 1 and ending September 30 is termed the "water year". It is designated by the year in which it ends. For example, the 12 -month period that began October 1, 1980, and ended September 30, 1981, was the "1981 water year". The succeeding years of study had progressively greater amounts of precipitation. Precipitation during the 1982, 1983, and 1984 water years was 104, 113, and 124 percent of normal, respectively. 


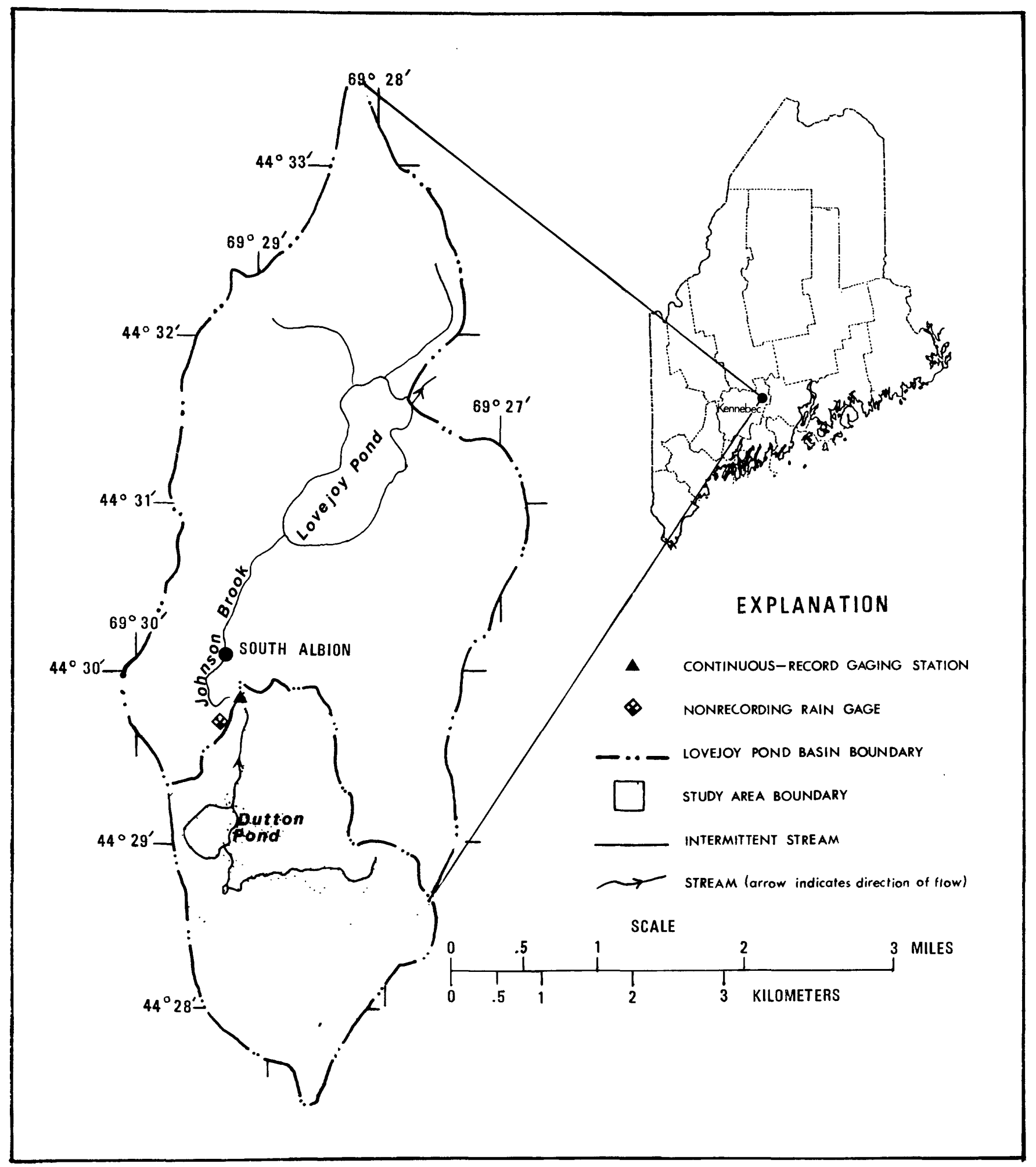

BASE FROM U.S. GEOLOGICAL SURVEY 1:62,500 QUADRANGLE MAPS: BURHNAM, 1957; WATERVILLE, 1957: VASSALBORO, 1958; LIBERTY, 1939.

Figure 1.--Location of study area and data-collection sites. 
Table 2.--Summary of precipitation data from National Weather Service station at Waterville Pumping Station, Waterville, Maine,

1980-84 water years

[A11 data in millimeters]

\begin{tabular}{|c|c|c|c|c|c|c|}
\hline $\begin{array}{l}\text { Study Period } \\
\text { Phase }\end{array}$ & $\begin{array}{r}\text { Water } \\
\text { Year }\end{array}$ & $\mathrm{Fal1}$ & Winter & Spring & Summer & Annual \\
\hline $\begin{array}{l}\text { Pre- } \\
\text { implemen- } \\
\text { tation }\end{array}$ & $\begin{array}{l}1980 \\
1981\end{array}$ & $\begin{array}{l}312 \\
226\end{array}$ & $\begin{array}{l}155 \\
126\end{array}$ & $\begin{array}{l}258 \\
254\end{array}$ & $\begin{array}{l}271 \\
338\end{array}$ & $\begin{array}{l}996 \\
944\end{array}$ \\
\hline Transition & $\begin{array}{l}1982 \\
1983\end{array}$ & $\begin{array}{l}384 \\
180\end{array}$ & $\begin{array}{l}183 \\
306\end{array}$ & $\begin{array}{l}295 \\
455\end{array}$ & $\begin{array}{l}233 \\
250\end{array}$ & $\begin{array}{l}1095 \\
1191\end{array}$ \\
\hline \multirow{3}{*}{$\begin{array}{l}\text { Post- } \\
\text { implemen- } \\
\text { tation }\end{array}$} & 1984 & 369 & 272 & 512 & 148 & 1301 \\
\hline & $\begin{array}{l}\text { Mean for } \\
\text { study period }\end{array}$ & 294 & 208 & 355 & 248 & 1105 \\
\hline & $\begin{array}{l}\text { Mean for } 25 \text {-year } \\
\text { period of record }\end{array}$ & 362 & 201 & 252 & 255 & 1070 \\
\hline
\end{tabular}

\section{Strcamflow}

Data collected at the gaging station provided detailed information on storm event and base-flow runoff conditions. Mean daily streamflow data for the investigation are presented in table 3 (at the end of this report). A summary of the monthly and annual streamflow statistics is presented in table 4 .

The summary table shows that total annual streamflow increased during each successive year of the investigation. This increase is directly related to the availability of water from increased precipitation as noted in the previous section. Comparison of the totals for the 1981 and 1984 water years, representing the preimplementation and postimplementation periods, respectively, shows a 225 percent increase in streamflow, which corresponds to a 40 percent increase in precipitation. Because streamflow in the latter part of the study was much greater than that recorded in the first year, the potential existed to transport greater quantities of phosphorus.

The reason for the dramatic increase in streamflow with respect to precipitation can be explained by the interaction among components of the hydrologic budget. Precipitation is the primary input component of the budget, and evapotranspiration and surface-water runoff comprise the major output components. Ground-water storage and movement are other major components of the cycle, but they were considered insignificant for the 
purpose of this study, given the geohydrologic and topographic characteristics of the study area and the typical cyclic nature of annual ground-water-level fluctuations. The output attributed to evapotranspiration is approximately half the annual average precipitation rate. In the study area, this amounts to about 510 to $635 \mathrm{~mm}$ of evapotranspiration each year (Knox and Nordenson, 1955). Thus, assuming that the evapotranspiration rate is about half the precipitation in 1981 and 1984 and that ground-water storage changes are negligible, the remaining precipitation left the watershed as increased surface-water runoff.

Comparison of streamflow hydrographs of storm events (see "Selected Storm Events Section") commonly indicated a double peak in stream stage. The initial peak is attributed to surface runoff from that part of the study area below Dutton Pond. The secondary peak, which usually was less then the first, followed the initial peak by about 6 hours. This peak is attributed to streamflow from the drainage area above Dutton Pond. The delayed stage rise indicated that Dutton Pond buffered extreme storm-runoff peaks.

\section{Acknowledgments}

Al1 the farmers in the Lovejoy Pond watershed and, in particular, Richard Pearson and Keith Noyes in the Johnson Brook study area are thanked for their willingness to implement the farm-management plans. Thanks are extended to Dorothy and Clayton Mason for collection of precipitation data throughout the 5-year study.

The U.S. Department of Agriculture's Soil Conservation Service was particularly supportive of the study. The agency was instrumental in development of the agricultural BMPs by providing the expertise of Randy Doak, Tyler Libby, and William Moulton.

The staff of the National Weather Service in Portland, Maine, are thanked for their forecasts of precipitation events. Consultation with them was offered at all hours and the accuracy of forecasts enabled a high percentage of runoff events to be sampled.

Special acknowledgment is due William J. Nichols, Jr. of the U.S. Geological Survey and David Dominie of the Maine Department of Environmental Protection. These individuals were responsible for getting the project underway and also completed most of the first 2 years of data collection. Their contribution to the study was invaluable and much appreciated.

\section{METHODS}

\section{Land-use information}

Information concerning land-use and agricultural practices was obtained through several sources. Aerial photographs and U.S. Geological Survey topographic maps were measured with an electronic digitizer to determine the extent of the land-use categories. Details of usage and practice information were provided by the Kennebec County District Conservationist and Planner and the farmers. 


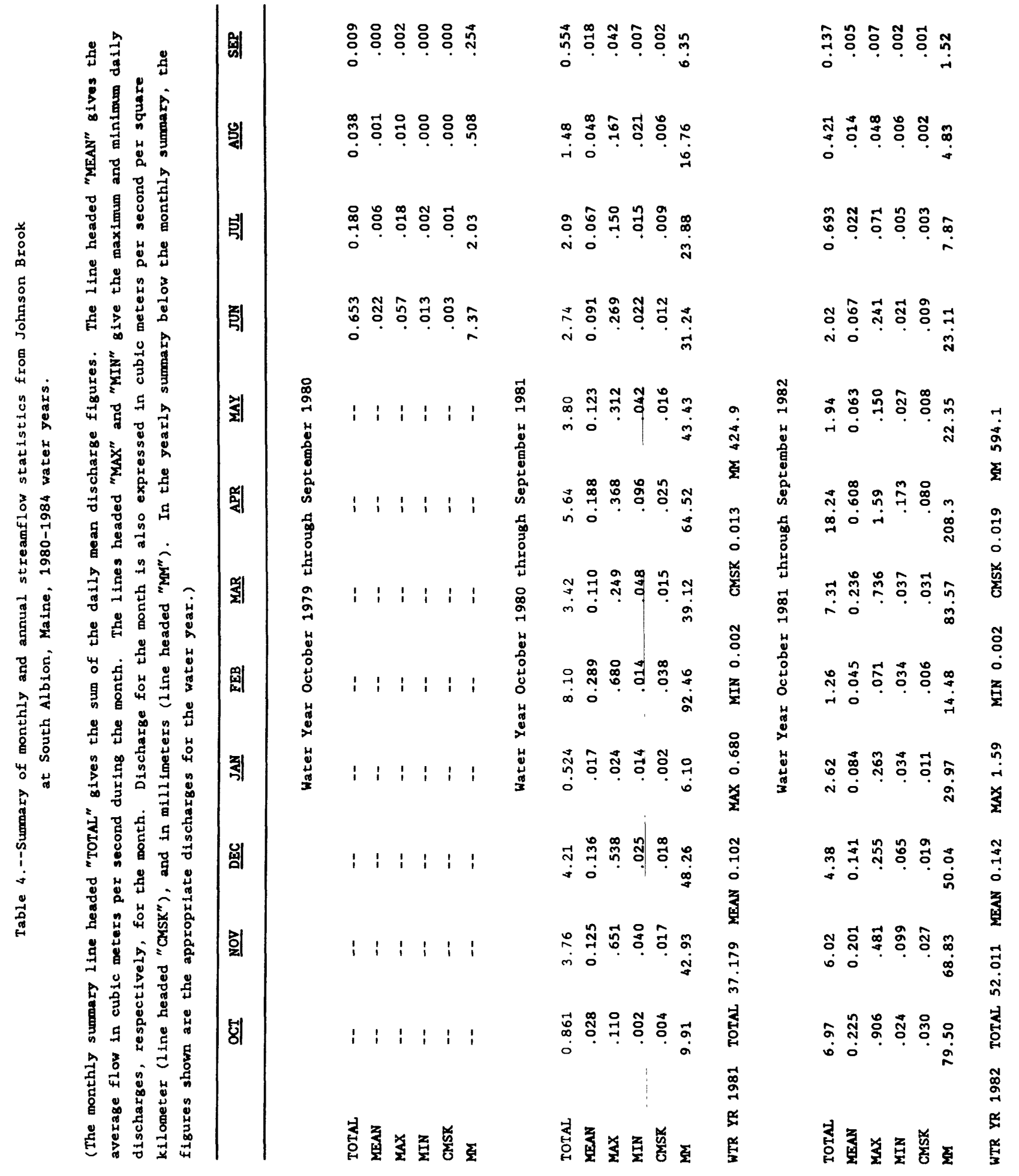




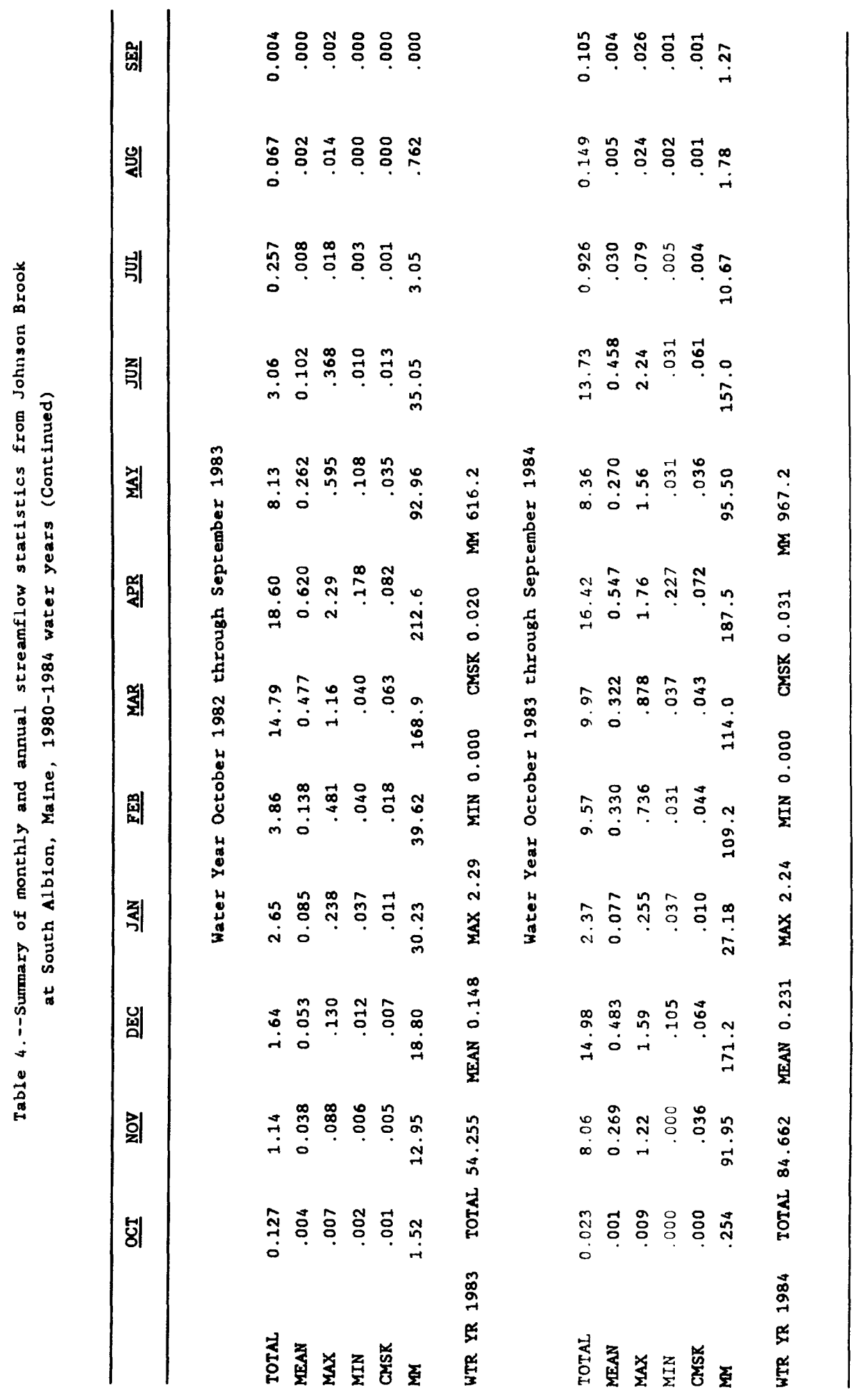




\section{Hydrologic and Water-Quality Data Collection}

Precipitation data were used to compare hydrologic conditions observed during the study period to long-term averages. The National Weather Service station in Waterville, Maine, about $16 \mathrm{~km}$ northwest of the study area, provided a long-term precipitation database and it also provided data throughout the study period.

Precipitation data collected by a local observer were used to identify locally intense storms and help in analyzing streamflow records.

Streamflow data were obtained from a streamflow-gaging station installed immediately upstream from the culvert on Danforth Road. This data was used to compare hydrologic conditions during baseflow and storm periods. It was also used for computing seasonal and annual phosphorus loads. Overland flow of water is the primary means of phosphorus transport from the study area. Therefore, accurate streamflow records were critical for determination of phosphorus loading changes. Streamflows were measured and reported according to the techniques described by Rantz and others (1982).

Water samples were collected for analysis of total phosphorus and suspended sediment. During base-flow conditions, samples were collected just upstream of the Danforth Road culvert using a depth-integrated sampler according to the collection techniques described by Guy and Norman (1970).

Storm-runoff samples were collected using either the depth-integrated sample collection technique described above or through use of an ISCO automatic sampler. The intake of the automatic sampler was positioned in the center of stream flow. A study of cross-contamination using this type of sampler showed that values of the first sample collected after a significant instream concentration change would lag behind the actual instream concentration (Thomas and Eads, 1983). Therefore, three sample bottles were filled during each automated sampling period. The first bottle, which allowed the sample line to equilibrate with instream conditions, was discarded; the second was used for suspended-sediment analysis; and the third was used for total-phosphorus analysis. The sample interval was based on weather forecasts and antecedent soil-moisture conditions. At the beginning of a storm-runoff period, frequent sampling was desirable because of rapidly increasing phosphorus concentrations observed on the rising limb of streamflow hydrographs. After streamflow peaked and during the hydrograph recession, the phosphorus concentrations declined at a steady rate; thus, less-frequent sampling intervals could be used. The accuracy of phosphorus yields is very dependent on definition of the phosphorus concentration curve. Generally, a sample interval of 1 to 3 hours was found sufficient to define phosphorus concentrations during storm-runoff periods.

Use of brand names in this report is for identification purposes only and does not constitute endorsement by the U.S. Geological Survey or Maine Department of Environmental Protection. 
Seventy-two depth-integrated, cross-sectional samples were collected at varlous flow conditions throughout the study period and compared to simultaneously-collected automatic point samples. Linear regression analysis of the matched sets of total-phosphorus data showed an excellent comparison of the automatic versus manual samples. The regression had a slope of 1.016 , an intercept of -0.01 , and a correlation coefficient of 0.98 . Based on this analysis, automatic-sampler data were used without application of a correction factor. Analyses of manually collected samples across the cross-section indicated that the stream was always well mixed.

The automated phosphomolybdate procedure for determination of total phosphorus described by Skougstad and others (1979) was modified to enable detection of concentrations in the 0.001 to $0.100 \mathrm{mg} / \mathrm{L}$ (milligrams per Liter) range (Elvin and Hunt, 1985). Sediment concentrations were determined using the methods described by Guy (1969).

\section{Measurement of Phosphorus Yield}

The procedure for computation of phosphorus yield was that described by Porterfield (1972) for computation of fluvial-sediment discharge. Data required for the computations included continuous streamflow records and phosphorus concentration analyses.

\section{Base-flow Periods}

Base-flow period phosphorus yields were determined using the following equation:

where

$$
P y=Q w \times P c \quad x \quad 86.4
$$

Py is the phosphorus yield, in kilograms per day;

Qw is the mean-daily water discharge, in cubic meters per second;

$\mathrm{Pc}$ is the concentration of phosphorus, in milligrams per liter; and

86.4 is a coefficient needed to compute yield on a daily basis as kilograms of phosphorus (Py) when using daily discharge measurements $(\mathrm{Q})$, in cubic meters per second per day, and flow-weighted mean daily phosphorus concentrations (Pc).

Phosphorus concentration values for the base-flow periods, Pc, were estimated using curves developed from available data by a method similar to that of Leitman and others (1983). A straight-line interpolation was made between phosphorus data points when the flow hydrograph was linear. When minor precipitation and snowmelt events caused elevations in the flow hydrograph, smoothed curves were developed through the phosphorus data following the shape of the streamflow hydrograph.

Baseflow phosphorus yield and concentration data were compared to assess the effectiveness of BMP implementation during low-flow periods. This assessment is especially important during the summer season. 


\section{Storm Periods}

According to Porter (1975), a major fraction of the total phosphorus carried out of a watershed by a stream is associated with particulate matter suspended in the water, much of which is delivered during a relatively short period of time when the discharge rate is very high. Streamflow is the phosphorus-transport mechanism, and peak-discharge periods associated with storm events are identified as the time when most transport will occur.

Phosphorus yields during storms were determined using the same types of data as were used during base-flow periods. An example of the procedure is shown in figure 2. The first step is to develop time plots of the streamflow and phosphorous concentration data. A streamflow hydrograph can be drawn using a smoothed line between the plotted points. Development of the phosphorous concentration graph can be hampered for many of the same reasons as Porterfield (1972) notes regarding sediment concentration curve development:

"Difficulties may be encountered while drawing the continuous graph because of paucity of samples, unusual storm events, or periods of missing record. When these difficulties arise guidance may be available from past record including plots of concentration values with time or stream stage."

The mid-interval subdivision technique described by Porterfield (1972) was used to compute daily phosphorus loads as follows: For each day of the storm, hourly streamflow discharges and phosphorus concentration values were read off the corresponding hydrographs and tabulated as in figure 2. Hourly discharge was multiplied by the concurrent phosphorus concentration to provide an hourly load. The mean hourly load, in kilograms, for each day was then multiplied by 86.4 (a constant accounting for seconds per day and milligrams per kilogram) in order to estimate daily loads, in kilograms of phosphorus.

Individual storm events from the three phases of the study were compared to determine the effectiveness of the BMPs. Storm events with similar hydrograph characteristics were selected to provide valid comparisons. Criteria for selection were (1) similar peak discharge, (2) comparable antecedent moisture conditions, (3) adequate data coverage, (4) season, and (5) comparable herd size.

\section{Seasonal and Annual Periods}

Phosphorus loadings, before and after BMP implementation, were compared on an annual and seasonal basis. Annual comparisons were based on the water year (October through September). Seasonal comparisons were made using four seasons defined as: Fall (October, November, and December), winter (January, February, and March), spring (Apri1, May, and June), and summer (July, August, and September).

These annual and seasonal periods coincide well with observed hydrologic patterns and reasonably we11 with farming practices. Most streamflow occurs during spring when soils are either frozen or saturated, the snowpack is melting, and spring rains occur. Springtime farming activities include manure spreading, plowing, and planting. Summer is typically a low-streamflow period and soils are not saturated because crops and other vegetation are using large 

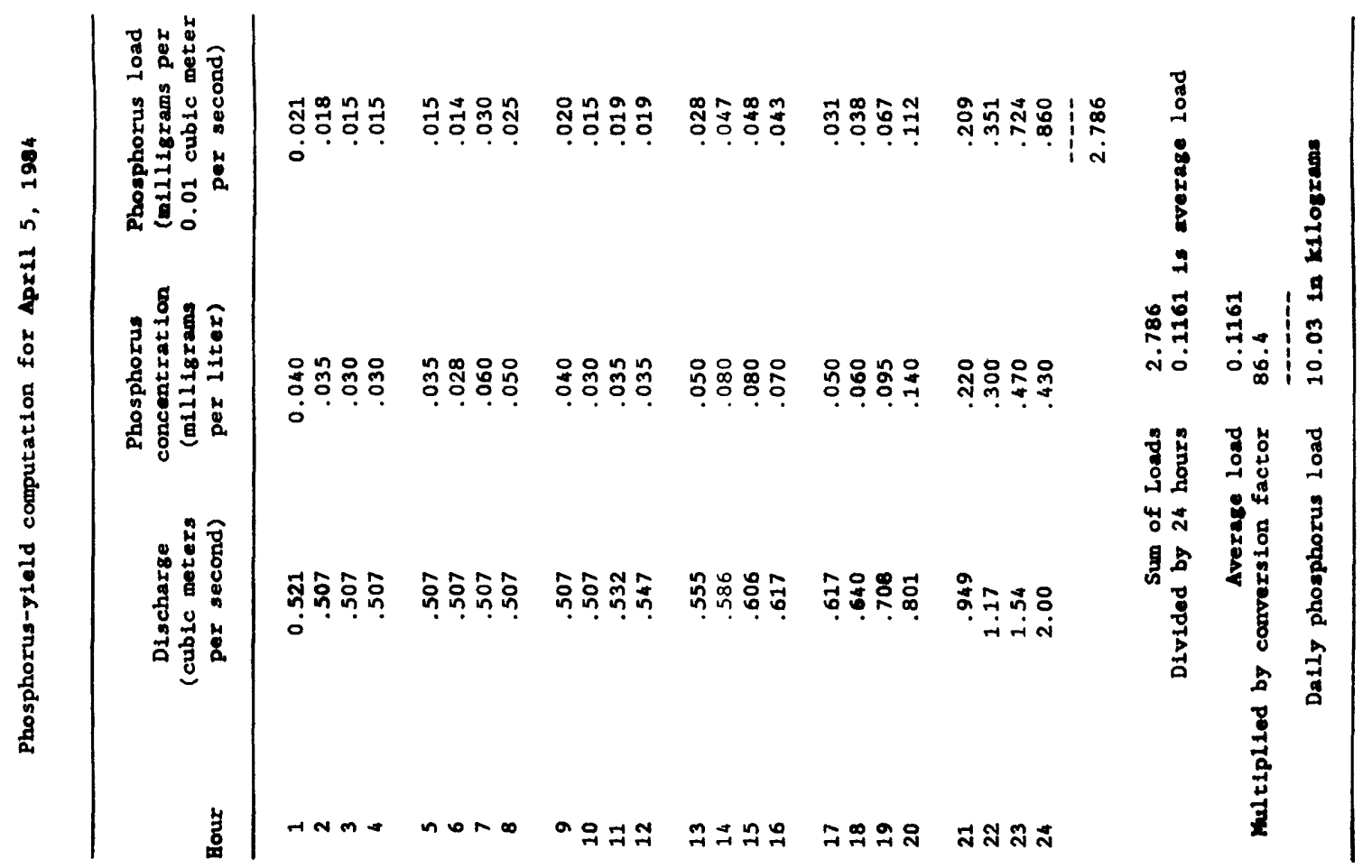

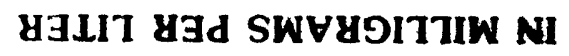
'NOILYYLNGONOO SRYOHASOHd

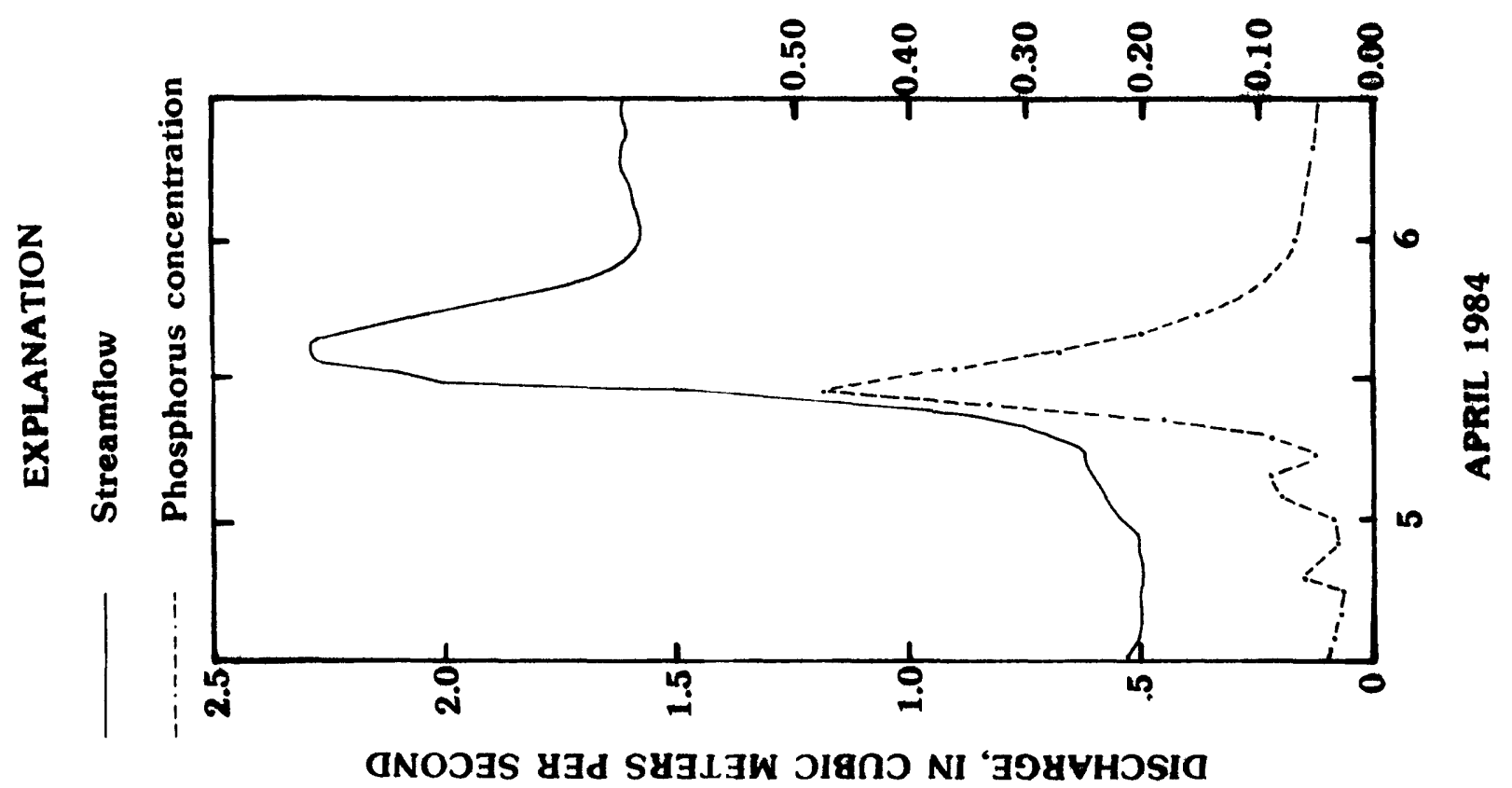


quantities of water. Precipitation usually is adequate to replenish waterused by vegetation. Manure is stored during the summer until after harvest. Moderate streamflow and spreading of manure stored during the sumer occurs during the fall. Freezing of solls begins in late fall. The winter months are again typically a period of low flow, although rainfall during winter is capable of producing a high-flow event, because frozen solls do not permit significant infiltration. This factor is important, because winter spreading of manure over snow-covered fields. was a common practice before implementation of BMPs.

The annual and seasonal phosphorus loads also were compared after the data were normalized based on a herdsize of 100 animals. This was done to factor out the variable of herdsize and allow interpretation of changes with respect to implementation of BMPs.

\section{Statistical Analysis of Daily Streamflow and Phosphorus Yield Data}

Statistical analyses of phosphorus yield data were made to determine the effect of the BMP's in different streamflow conditions. Daily phosphorus yield data for the preimplementation and postimplementation periods were sorted by increasing streamflow. The data were grouped into five flow categories, which were separated at convenient flow intervals. The intervals used were: less than $0.025 \mathrm{~m}^{3} / \mathrm{s}$ (cubic meters per second), $0.025 \mathrm{~m}^{3} / \mathrm{s}$ to 0.10 $\mathrm{m}^{3} / \mathrm{s}, 0.10 \mathrm{~m}^{3} / \mathrm{s}$ to $0.20 \mathrm{~m}_{3}^{3} / \mathrm{s}, 0.20 \mathrm{~m} / \mathrm{s}$ to $0.30 \mathrm{~m}^{3} / \mathrm{s}$, and greater than $0.30 \mathrm{~m}^{3} / \mathrm{s}$. The "less than $0.025 \mathrm{~m}^{3} / \mathrm{s}$ " flow category has the greatest amount of data for both periods and is representative of conditions at or near baseflow. The next three intervals represent loading conditions in the low medium, medium, and high medium levels of streamflow. The "greater than $0.30 \mathrm{~m} / \mathrm{s}$ " category represents the high streamflow conditions. The phosphorus data in each of these categories were statistically analyzed using Minitab Data Analysis Software (Minitab Inc., 1985). The distribution of daily phosphorus loads for each category was arranged in paired boxplots to graphically illustrate results. Because the daily phosphorus load data are not normally distributed, a non-parametric Mann-Whitney rank test was used to determine if there were significant differences between preimplementation and postimplementation period phosphorus yield data. Percent differences were computed using the median values from the preimplementation and postimplementation periods in the five flow categories.

\section{AGRICULTURAL PRACTICES}

\section{Land-Use}

Although forest is the predominant land-use type (78 percent of area), agriculture (19 percent of area) is the land use cited by Sowles and Dominie (1984) as the primary source of phosphorus.

Table 5 shows that 59 hectares of agricultural land or 40 percent of the total amount of agricultural land is downstream from Dutton Pond. Typical agricultural land uses and crops include pasture, corn, hay, and silage production to support dairy farming. Manure from the dairy herd is spread on the croplands for use as fertilizer. Supplemental applications of commercial fertilizers are made occasionally. 
Table 5.--Land use in the Johnson Brook study area after

implementation of best-management practices

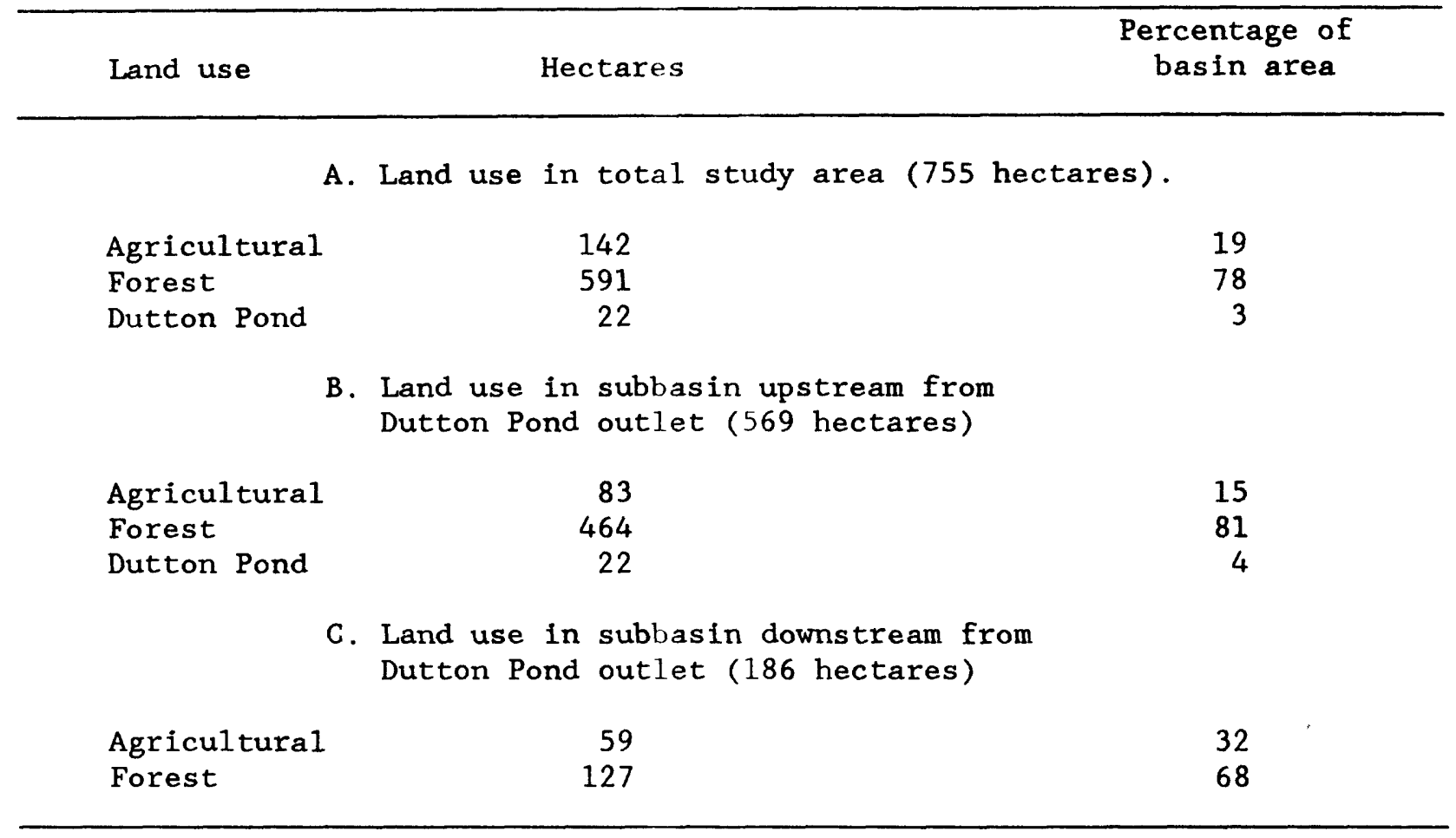

\section{Best-Management Practices}

Two dairy farms are the primary users of the agricultural 1 and in the Johnson Brook study area. One farm abuts about 300 meters of the brook, and the other is located on the eastern ridge of the drainage divide. Owners of these farms signed cooperative agreements with the Kennebec County Soil and Water Conservation District to implement a farm-management plan formulated by the District. Three categories of "Best-Management Practices" were designated to alleviate phosphorus-loading problems.

The first BMP required changes in land use that would reduce soil erosion. Prior to BMP implementation, crops had not been planted according to any plan but were grown according to demand and convenience. For example, if more corn was needed, an idle hayfield or forested area was converted into cropland. Once in tillage, crops were grown year after year with little or no planned rotation. The cooperative agreements required that tilled croplands on steep slopes, on erodible soils, or next to streams be used solely for growing hay. Loss of tilled croplands was compensated by converting hayland on shallow slopes at acceptable distances from waterways into tilled cropland. Where this was not possible, new cropland or hayland was made from forested land. As a minimum requirement, all tilled cropland was put on a 3 -year rotation with grass. In cases where slopes were excessive, stripcropping with grass on a 3 - to 5-year rotation was implemented. 
The land-use patterns before and after implementation of agricultural BMPs are shown on figure 3. More than half of the agricultural land was modified in accordance with the BMP agreements.

The second BMP required farmers to discontinue the practice of spreading manure on frozen ground. Much of this manure presumably was being washed into Johnson Brook during snowmelt and rains. The cooperative agreement included funding from the Conservation District for construction of manure-storage facilities to allow discontinuation of this practice. The facilities were designed to hold the manure that the farmer's herd would generate for the 8 -month period from October through May. The owner of the farm adjacent to Johnson Brook signed an agreement in August 1981, and storage began by November 1981. The owner of the other farm signed an agreement in February 1982 and temporarily stacked manure in a field where erosion would be minimal until permanent storage was constructed in the summer of 1982. The location of the storage facilities are shown on figure 3. The facility for the farm on the eastern ridge of the drainage divide was constructed just outside the study area watershed.

The third BMP was to prevent farm animals from having direct contact with the brook. The plan required that fencing be erected to prevent animals from wading into the brook. A fence was erected about 15 meters upgradient from the normal spring high-water mark to meet this requirement. In addition, the BMP provided a buffer strip in which runoff from the pasture could be partially treated through infiltration and the entrapment of particulate matter.

\section{Changes During Study}

Herd size

Numbers of dairy cattle within the study area changed significantly during the study period. The dairy herd was stable at about 120 head during the first year of the project. However, 55 head were sold by the fall of 1981. The herdsize was gradually built back up until it reached 100 head in October 1983, and remained constant at about 100 throughout the final year of the study.

\section{Other Changes}

During the study period, agricultural land area increased slightly and the proportion of tilled to nontilled land dropped slightly as a result of BMP implementation. Use of commercial fertilizers was presumably reduced slightly through more efficient farming resulting from BMPs implementation.

\section{EFFECTS OF BEST-MANAGEMENT PRACTICES ON TOTAL PHOSPHORUS YIELDS}

Total phosphorus is generally regarded as the measurement most appropriate for lake eutrophication modeling (Vollenweider, 1976). A criterion for total phosphorus, designed to prevent or control nuisance growth of algae or other aquatic plants, has been proposed by the USEPA (U.S. Environmental Protection Agency) (1977). The USEPA has suggested that the total-phosphorus concentration for any stream, at the point where it enters a 


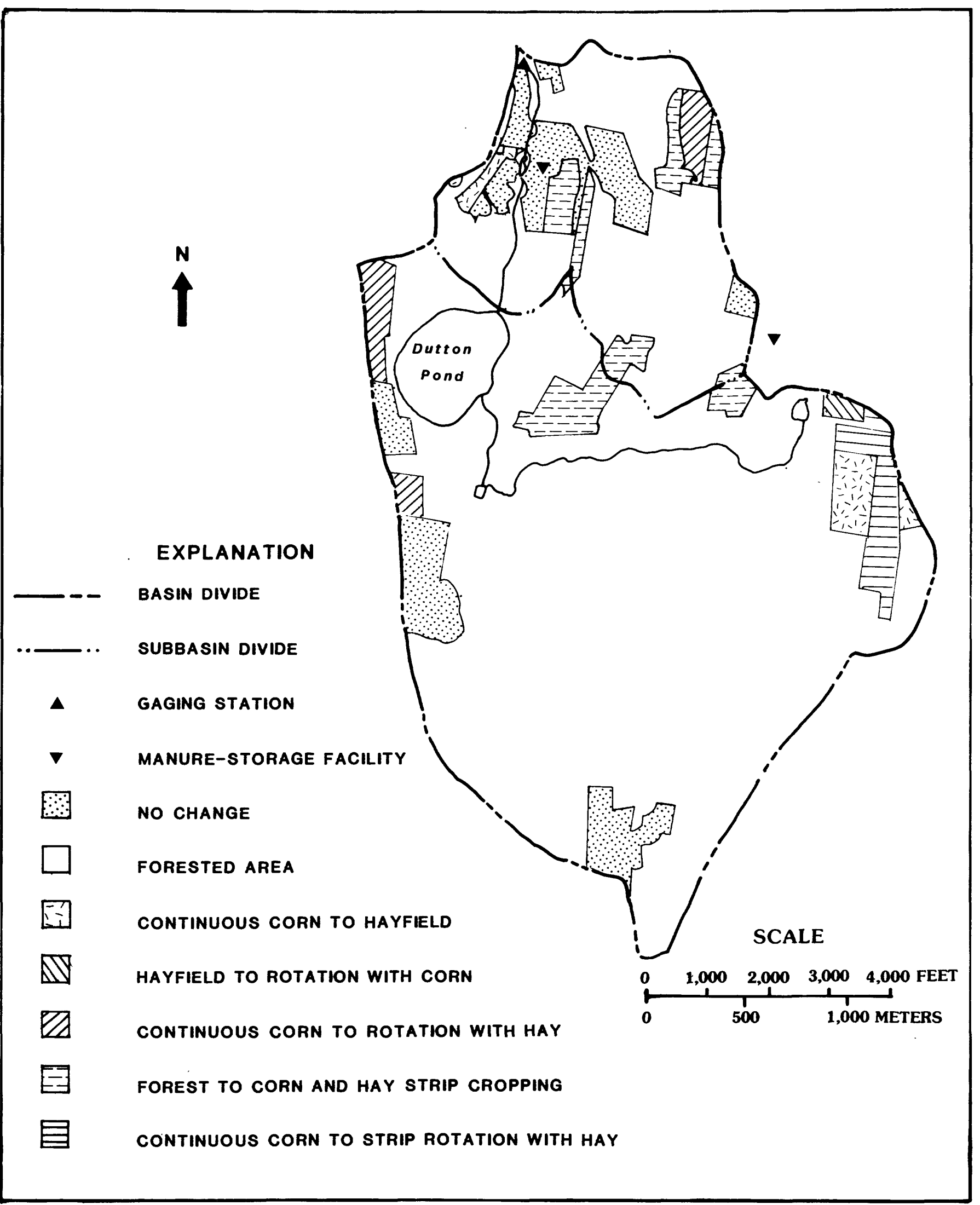

Figure 3.--Agricultural land-use map. 
lake or reservoir, not exceed $0.05 \mathrm{mg} / \mathrm{L}$ and that the concentration within the lake or reservoir not exceed $0.025 \mathrm{mg} / \mathrm{L}$. During examination of data from a number of studies, Hammer and Mackichan (1981) found that the commonly accepted critical phosphorus concentration in lakes during spring overturn was $0.01 \mathrm{mg} / \mathrm{L}$. At this leve 1 or lower, lakes had no excessive algae growth during the growing season. Observed phosphorus levels greater than $0.02 \mathrm{mg} / \mathrm{L}$ during spring overturn produced eutrophic conditions throughout the lake.

Total-phosphorus and suspended-sediment concentration data for the 1980 and 1981 water years are presented in Maloney and others (1983). Phosphorus and sediment data collected during the 1982-84 water years are presented in table 6 (at the end of this report). Daily-phosphorus yields, computed for the period June 1980 through September 1984, are presented in table 7 (at the end of this report).

Phosphorus yields during the three phases of the study were compared to determine the composite effectiveness of the BMPs. Comparisons were made of samples collected and yields determined during base-flow, storm-event, and seasonal and annual periods. Evaluation of reduction in phosphorus loads resulting from implementation of the BMPs was used to determine if eutrophic conditions in Lovejoy Pond would change.

Although samples were collected and analyzed for suspended sediment concentrations, subsequent evaluation showed that there were insufficient numbers of samples collected during the preimplementation period to allow a valid comparison. Consequently, suspended sediment data was not interpreted.

\section{Yields in Base Flow}

Total-phosphorus concentrations observed during base-flow periods in the preimplementation phase of the study were consistantly higher than the USEPA suggested limit for the streams entering lakes or impoundments. In the summer of 1980, phosphorus concentrations in instantaneous base-flow samples ranged from $0.100 \mathrm{mg} / \mathrm{L}$ to $0.570 \mathrm{mg} / \mathrm{L}$ with an average of about $0.250 \mathrm{mg} / \mathrm{L}$. A period of remarkably high phosphorus concentrations was observed in the late summer and early fall of 1980 . Phosphorus concentrations in the 1.00 to $4.80 \mathrm{mg} / \mathrm{L}$ range were observed during early October when streamflow ranged from 0.002 to $0.037 \mathrm{~m}^{3} / \mathrm{s}$. Although streamflow during the month was low, a considerable phosphorus load was observed because of consistantly high phosphorus concentrations. This load was likely the result of dairy cattle having direct access to the stream below Dutton Pond. Phosphorus concentrations in baseflow samples observed during the summer of 1981 ranged from $0.050 \mathrm{mg} / \mathrm{L}$ to $0.240 \mathrm{mg} / \mathrm{L}$ with an average flow-weighted concentration of about $0.08 \mathrm{mg} / \mathrm{L}$. Although the number of dairy cattle had been reduced prior to this season, the phosphorus concentrations in baseflow were lower in the summer of 1981 compared to the summer of 1980 , probably as a result of flow conditions; precipitation was about $75 \mathrm{~mm}$ above normal and frequent periods of storm runoff flushed phosphorus sources, thereby reducing the amount of available phosphorus for baseflow.

Base-flow total-phosphorus concentrations observed in the transition and postimplementation phases of the study generally were lower than the preimplementation concentrations. The extended base-flow period during the summer of 1983 had streamflow and a herd size similar to that during the summer of 1980. Phosphorus concentrations observed during the 1983 period 
ranged from $0.029 \mathrm{mg} / \mathrm{L}$ to $0.090 \mathrm{mg} / \mathrm{L}$ with an average concentration about $0.055 \mathrm{mg} / \mathrm{L}$. This is a five-fold reduction of the concentrations observed during the summer of 1980 and is attributed to BMP implementation. Phosphorus concentrations during baseflow at other times of the transition and postimplementation phases were higher than the summer 1983 period - - up to 0.660 $\mathrm{mg} / \mathrm{L}$. A sustained period of elevated concentrations, as occured in the October 1980 preimplementation period, was not observed after BMP implementation.

Base-flow phosphorus yields probably have a minimal effect on Lovejoy Pond or other impoundments, because they contribute a relatively small part of the total annual load.

\section{Yields From Selected Storms}

The major preimplementation storms occurred during the winter of the 1981 water year; therefore, transition and post-implementation storms during that season were selected for comparison. This comparison of winter runoff events probably best illustrates changes in phosphorus yields due to the elimination of manure spreading on frozen ground. It does not provide a good representation of changes in phosphorus yields during other times of the year or for other runoff events.

The first storm set selected for the comparison consisted of three events: the preimplementation phase storm of February 2-3, 1981; the transition-phase storm of March 2-3, 1983; and a postimplementation storm on January 27-28, 1986. These storms were each considered major runoff events, with peak flows of $1.085,0.691$, and $1.756 \mathrm{~m}^{3} / \mathrm{s}$, respectively. The total streamflow discharged during the transition-phase storm was about two-thirds that of the preimplementation storm. The postimplementation storm had almost 3.5 times the total streamflow volume as the pre-implementation storm. Baseflow conditions prevailed for at least 30 days prior to each storm.

Hydrographs and phosphorus-concentration curves of these storms (fig. 4) illustrate the reduction of phosphorus observed after implementation of BMPs. Maximum phosphorus concentrations observed during the storms showed significant reductions. Concentrations reached $3.16 \mathrm{mg} / \mathrm{L}$ in the $1981 \mathrm{storm}$, $0.44 \mathrm{mg} / \mathrm{L}$ in the $1983 \mathrm{storm}$, and on $1 \mathrm{y} 0.2 \mathrm{mg} / \mathrm{L}$ in the 1986 storm. Total yields of phosphorus were about $110 \mathrm{~kg}$ (kilograms) for the 1981 storm, $13 \mathrm{~kg}$ for the 1983 storm, and $18.7 \mathrm{~kg}$ for the 1986 storm.

Comparing the first two storms, the lower yield of the transition-phase storm may be explained partially by the difference in streamflow and partially by farming practice changes in the watershed. In addition to the BMPs, the change in herdsize and accompanying reduction of manure in the watershed are also factors. However, the reduction in phosphorus transport indicates that the implementation of BMPs had a rapid effect on limiting the availability of phosphorus for transport from the basin.

The advantages of comparing the 1981 and 1986 events were that (1) the herd size for these two events was comparable, and (2) the postimplementation storm had a higher discharge than that of the storm during preimplementation. Also, the BMPs had been in effect for 3 years before the postimplementation event. The peak flow of the January 1986 storm was 60 percent greater than that of the February 1981 storm. Yet, the peak phosphorus concentration 


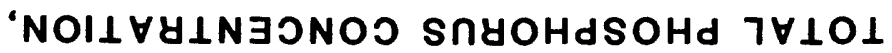
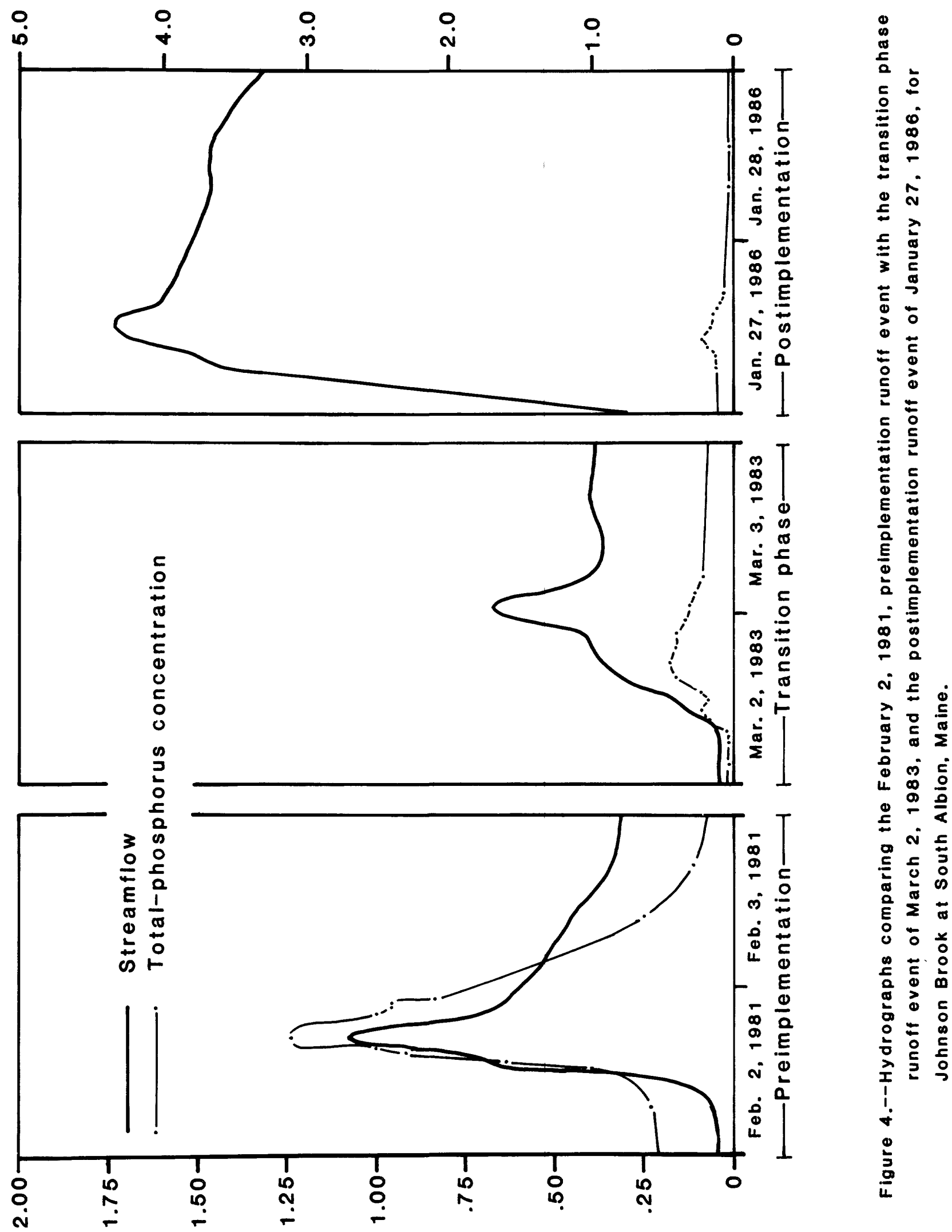

aNOJ 
during the 1986 storm was 93 percent lower than that of the 1981 storm, and the total-phosphorus yield for the storm was 83 percent lower. Observation of such a small yield during a larger storm indicates improvement of waterquality in the Johnson Brook watershed; this improvement can be attributed largely to the implementation of BMPs.

Another set of storms occurring on February 11, 1981, (preimplementation phase) and February 15, 1984, (postimplementation phase) were each preceded by about 1 week of base flow. The postimplementation storm had the higher peak discharge and a more sharply ascending discharge hydrograph which indicates the runoff from the storm had greater potential to transport phosphorus (figure 5). However, peak total phosphorus concentrations were much lower in the postimplementation storm $(0.63 \mathrm{mg} / \mathrm{L})$ than in the preimplementation storm $(2.0 \mathrm{mg} / \mathrm{L})$. Phosphorus yield during the storm runoff period was also much less with a $20 \mathrm{~kg}$ yield in the postimplementation storm compared to the $51 \mathrm{~kg}$ yield in the preimplementation storm.

\section{Seasonal and Annual Yields}

Streamflow and availability of phosphorus for transport are the two factors that control the yield of phosphorus in the Johnson Brook and Lovejoy Pond watersheds. Table 8 shows seasonal and annual data from Johnson Brook for both of these factors, as well as data on observed phosphorus yield. Figure 6 shows graphs of the annual data for discharge and phosphorus yield for the 1981-84 water years.

Discharge values show that spring was the season with the highest transport capability, followed by either fall or winter, depending on hydrologic conditions. Summer was the season with the lowest discharge and transport capability. Annual totals show that flows increased each year of the study, from a low of $37.2 \mathrm{~m} / \mathrm{s}$-days in 1981 to a high of $84.6 \mathrm{~m} / \mathrm{s}$-days (cubic meters per second days) in 1984 ( $f i g .6$ ), an increase of about 128 percent. At four long-term index stations in Maine, the 1984 water year annual runoff was excessive (within the highest 25 percent of record) ranging from 130 to 172 percent of normal.

Availability of phosphorus for transport was controlled by implementation of BMPs in 1982 and 1983 and by variation in herd size, as shown in table 8 . Herd size was reduced during implementation of BMPs and then increased to a stable level of about 100 head in 1984 .

The combined effects of variations in streamflow, implementation of BMPs, and changes in herd size in the Johnson Brook watershed can be seen in the two sections of table 8 that show observed total-phosphorus yields and total-phosphorus yields adjusted for changes in herd size. Seasonal data for the last 2 years of the study show that seasonal phosphorus ylelds followed the same pattern as hydrologic conditions. Spring was the season with the highest discharge and phosphorus yield and summer the season with the lowest discharge and phosphorus yield; contributions of phosphorus during the winter and fall ranked according to discharge. The close relation between discharge and phosphorus yield overshadowed the seasonal changes in BMPs and herd size. 


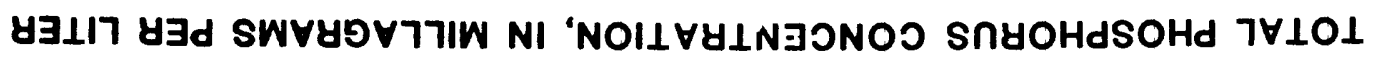

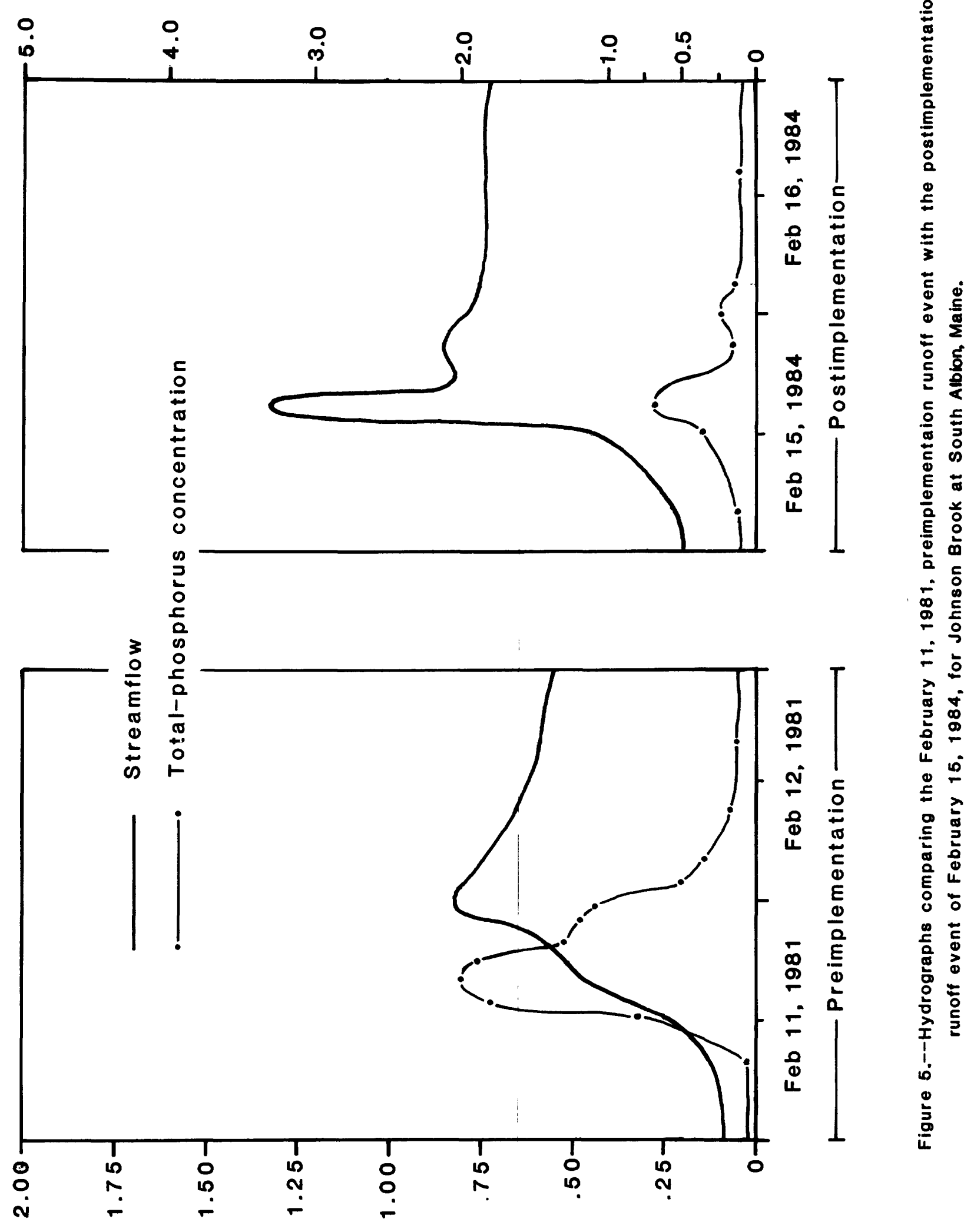

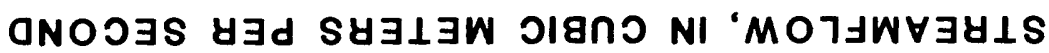




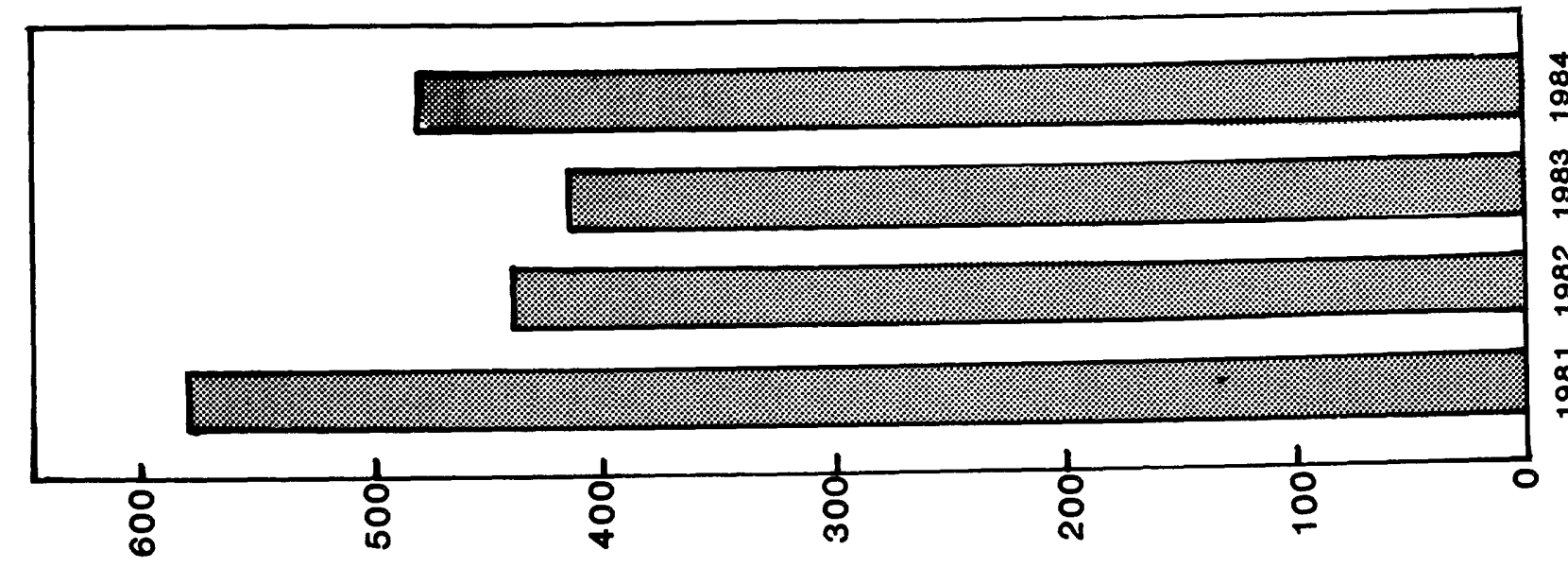

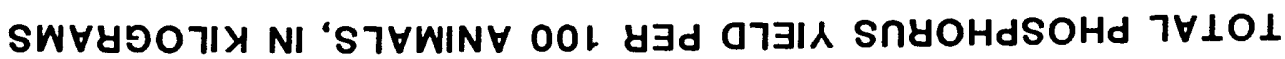
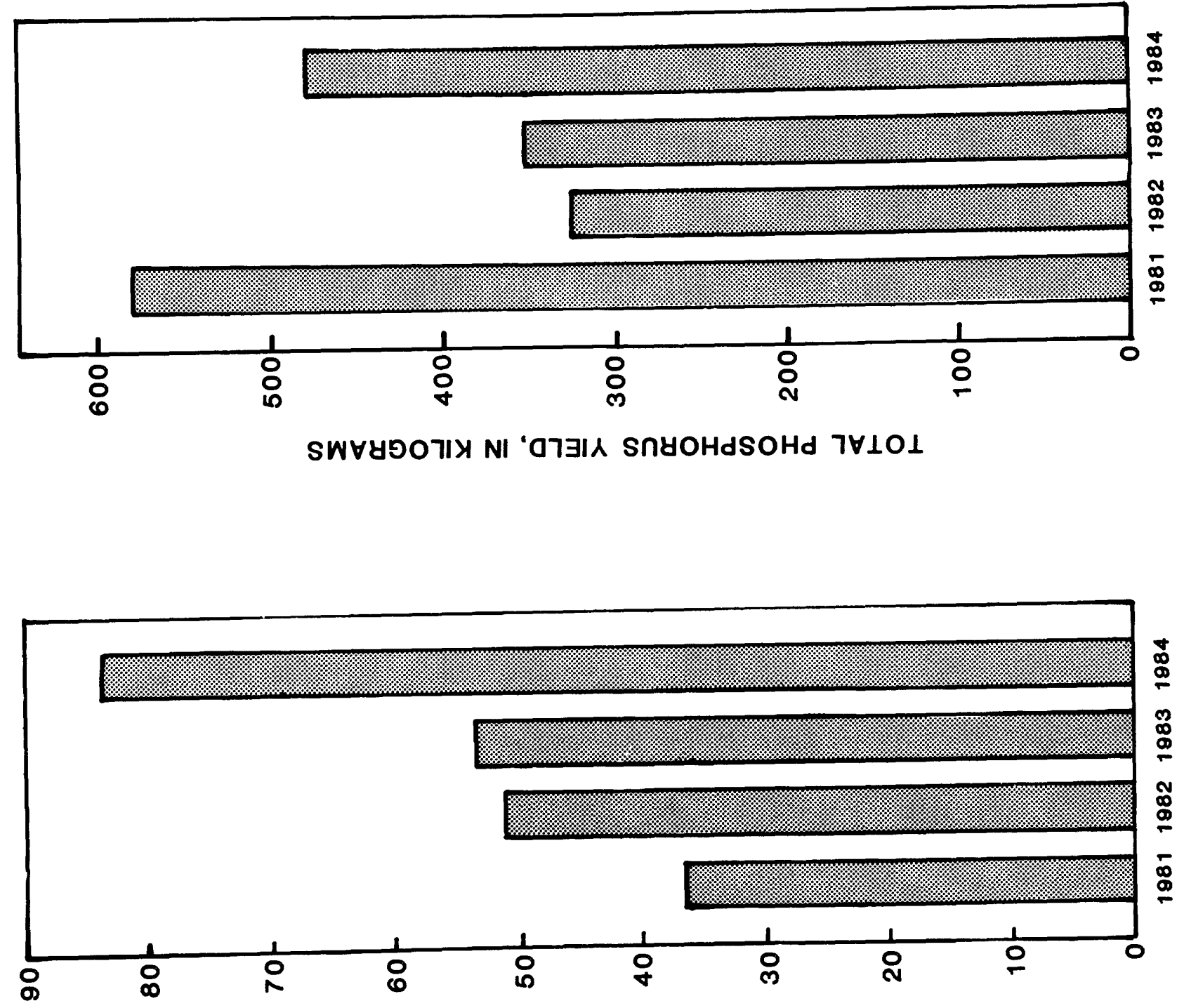

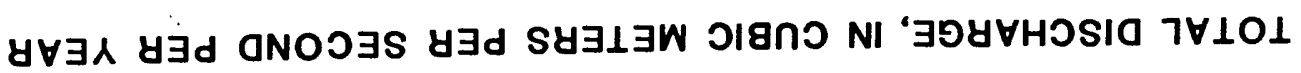


Table 8.--Sumnary of phosphorus yield totals, discharge totals, mean phosphorus concentrations, herdsize, and adjusted total-phosphorus load per 100 animals for Johnson Brook at South Albion, Maine, summer 1980 through summer 1984 .

$$
\text { [-- Indicates no data] }
$$

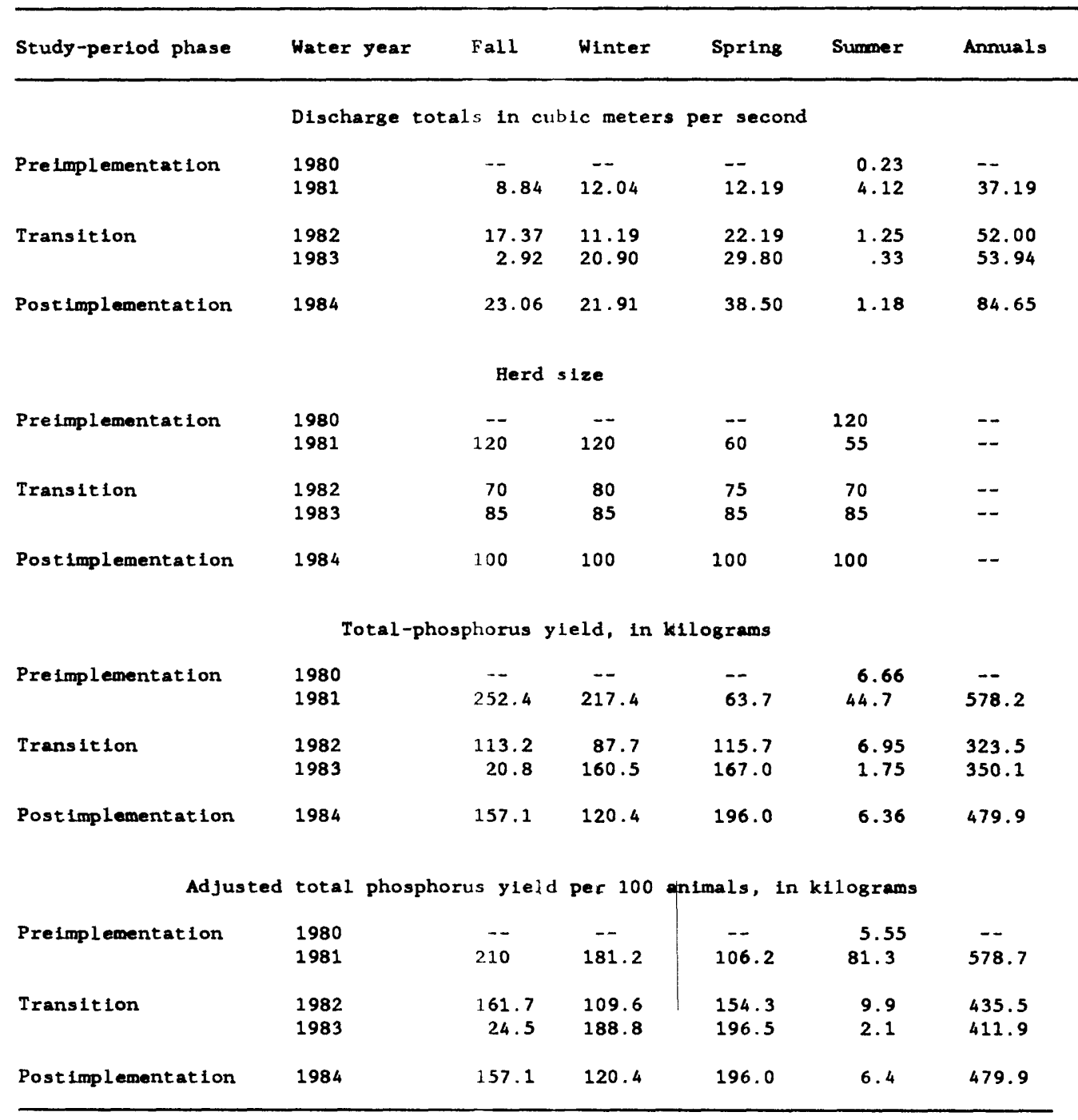


The most accurate evaluation of overall BMP effectiveness in reducing phosphorus yield is provided by comparing annual phosphorus-yield data normalized for changes in herd size. Calculated annual yields integrates seasonal variations in streamflow, and normalization to a standard herd size reduces the effects of changes in farm operations not related to BMP implementation. When calculated phosphorus yields were expressed as load per 100 animals, the results showed consistant reductions in 1982, 1983, and 1984, compared to preimplementation 1981 (see fig. 6). The reductions for 1982 , 1983, and 1984 compared to 1981 were 25, 29, and 17 percent, respectively. These reductions indicate that, under the conditions observed during this study, BMPs appear responsible for about a 25-percent reduction in the annual phosphorus yield from the Johnson Brook watershed.

\section{Statistical Analysis of Yields in Selected Streamflow Categories}

Simply comparing the entire daily phosphorus yield data for the preimplemenation and postimplementation periods did not yield statistically significant results because the loading data from different streamflow conditions masked each other and interfered with the analysis. When the phosphorus yield data were grouped into flow categories, the distinct subsets which were obtained allowed the use of conventional statistical comparisons.

The validity of the statistical comparison of data for the first four categories, the low and medium flow ranges, is sound because streamflow conditions were comparable for both periods. Comparisons of the high-flow (greater than $0.30 \mathrm{~m} / \mathrm{s}$ ) data sets are complicated because the postimplementation period had many days where streamflow greatly exceeded the maximum daily flow of the preimplementation period. A statistical comparison of the yield data from dissimilar flows would be biased because higher streamflow has the potential to transport a greater phosphorus load. However, eliminating the yields corresponding to the extremely high flows of the postimplementation period might lead one to conclude that yields for the period were lower only because the highest flow yields were not included in the comparison. Because all "greater than $0.30 \mathrm{~m} / \mathrm{s}$ " values in the preimplementation and postimplementation groups were considered in the analysis, the results for the high-flow comparison are a conservative estimate of changes after BMP implementation.

Paired boxplots of the preimplemenation and postimplementation phosphorus yield data for the five flow categories are presented in figure 7 . The boxplots provide a visual summary of the medium, interquartile range, and extreme values of daily phosphorus yields for each data set. If the median is about equidistance from the 25 th percentile and the 75 th percentile, it is an indication that the data are normally distributed. Because the median is not equidistance from the two percentiles in the plots of figure 7 , the data are not normally distributed and nonparametric techniques were used for statistical comparison. The series of plots also shows that phosphorus loading increases with greater streamflow. Comparison of the paired boxplots shows that phosphorus yields are consistently less in the postimplementation period than during the preimplementation period for each of the five flow categories. In the high flow category this was true despite the fact that the postimplementation period had significantly higher streamflow. 

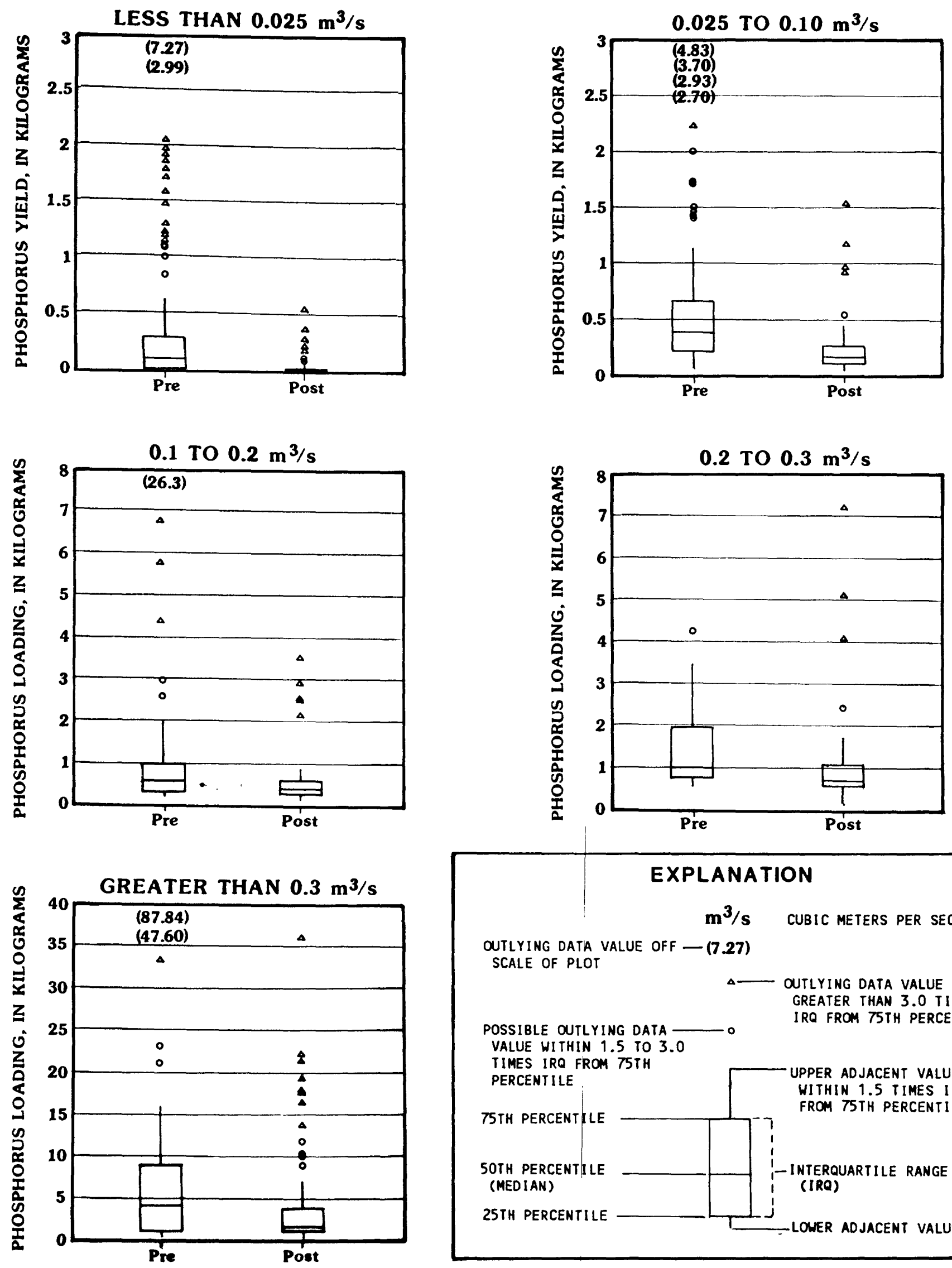

\section{EXPLANATION}

$\mathrm{m}^{3} / \mathrm{s}$ CUBIC METERS PER SECOND

OUTLYING DATA VALUE OFF - (7.27) SCALE OF PLOT

$\triangle$ - OUTLYING DATA VALUE GREATER THAN 3.0 TIME

POSSIBLE OUTLYING DATA IRQ FROM 75TH PERCENTILE

VALUE WITHIN 1.5 TO 3.0

TIMES IRQ FROM 75TH PERCENTILE

75TH PERCENTILE

5OTH PERCENTI LE (MEDIAN)

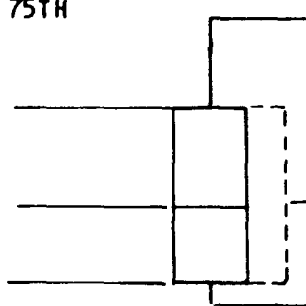

UPPER ADJACENT VALUE WITHIN 1.5 TIMES IRQ FROM 75TH PERCENTILE

25TH PERCENTILE 
Differences in phosphorus yields before and after BMP implementation are presented in a statistical summary of data for the five flow categories (table 9). Comparison of the median and interquartile range values show that phosphorus yields were lower in the postimplementation period for each streamflow category.

The Mann-Whitney Rank Sum test, a nonparametric technique used to make comparisons of nonnormally distributed data, was applied to the data in each streamflow category. The null hypothesis for this test was that there was no difference in phosphorus yields between the preimplementation and postimplementation periods and the alternate hypothesis was that phosphorus yields in the postimplementation period were less than those of the preimplementation period. The results of these tests indicate that the phosphorus reductions were significantly different at the 95-percent confidence level for all but the 0.10 to $0.20 \mathrm{~m} / \mathrm{s}$ flow category which had a confidence level of 92.9 percent (calculated from 1.0 minus the $p$ value (the smallest level of significance that would have allowed the null hypothesis to be rejected) times 100 percent or $(1.0-0.0706) \times 100)$. For the lower flow classes, the records analyzed encompass large numbers of consecutive days. The estimated loads for these days are highly serially correlated, but the Rank Sum test is based on independence. Thus, the p-values for the test (e.g., 0.0000) are a bit stronger than they should be if one could adjust the test for this correlation. The group differences are so great, however, that there can be no doubt that these groups are really different. Percent reduction in phosphorus yields for each category was determined by dividing the difference in yield for the two periods by the yield observed in the preimplementation period. The reduction in phosphorus yields for the selected flow categories ranged from 26 to 90 percent. Although the 90 percent reduction in median daily loads in the lowest streamflow category seams dramatic, this category only accounted for about 10 percent of the preimplementation load. More important, in terms of lake eutrophication, is the 60 percent reduction of median loads in the highest stream flow category which accounted for more than half the preimplementation load.

\section{Effects of Yields on Eutrophication of Lovejoy Pond}

The second objective of this study was to estimate the effect that reduction in phosphorus loading to Lovejoy Pond would have on the pond's water quality. BMPs were implemented on 22 farms throughout the entire watershed of Lovejoy Pond. Extrapolation of the results from the Johnson Brook study to the remainder of the watershed provided the means to estimate the expected changes in Lovejoy Pond water-quality conditions.

An annual phosphorus load of from 750 to $1,000 \mathrm{~kg}$ was determined as the primary factor controlling primary productivity in Lovejoy Pond before BMP implementation (Sowles and Dominie, 1984). If the 25-percent reduction of phosphorus yield observed in the study area is applied to the entire lake watershed, the new load then would be from 525 to $750 \mathrm{~kg}$. In-pond phosphorus concentrations, determined by applying these loads to Vollenweider's (1976) lake model, would be reduced from $0.040 \mathrm{mg} / \mathrm{L}$ to $0.030 \mathrm{mg} / \mathrm{L}$. The new level is still above the $0.020 \mathrm{mg} / \mathrm{L}$ criterion reported by Hammer and MacKichen (1981) for development of eutrophic conditions. Further efforts must be made to improve BMPs in order to control phosphorus movement off agricultural land. 


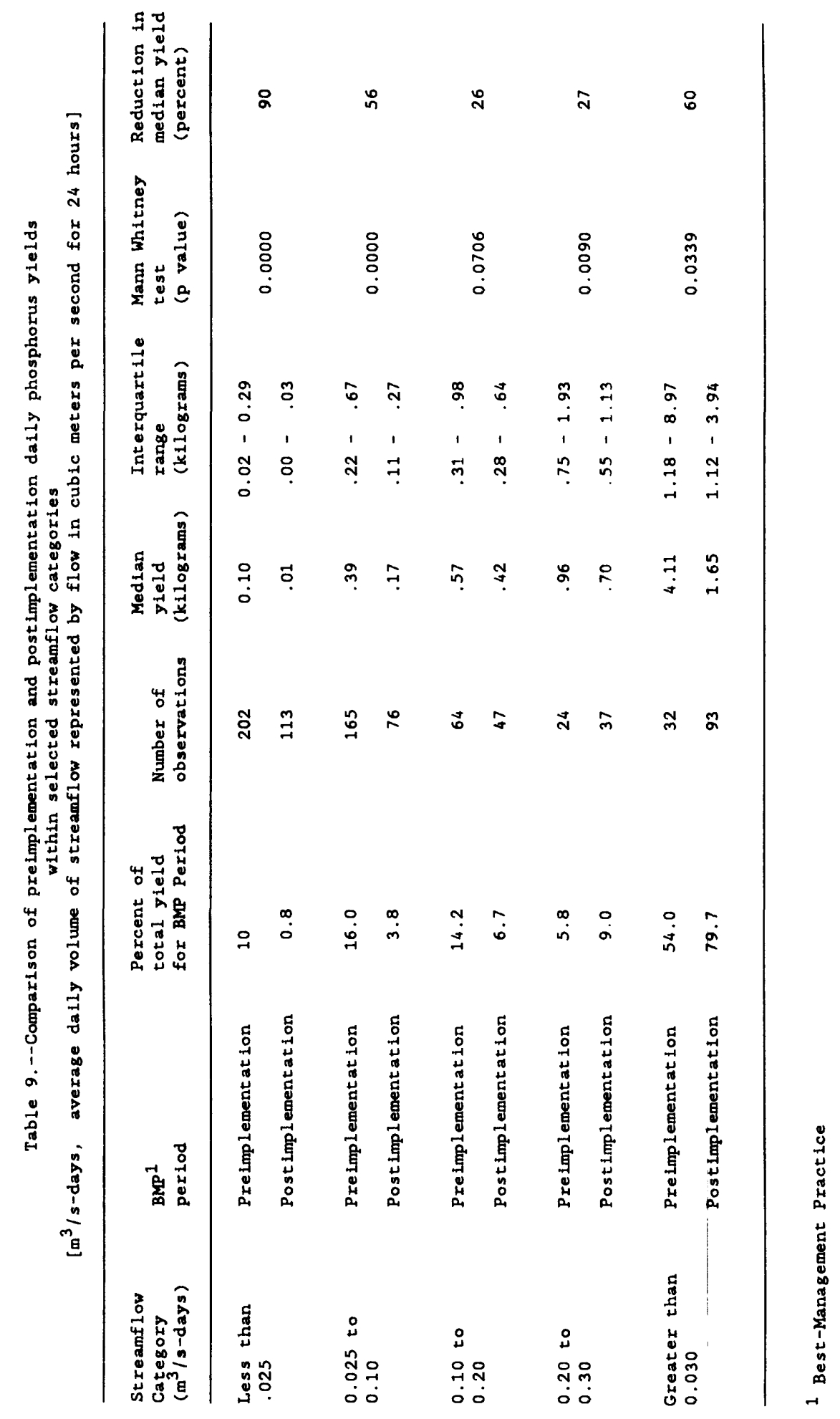


Practices intended to control soil but not restrict water movement have not proven to be sufficiently effective methods of controlling phosphorus.

Although significant reductions in phosphorus concentrations and yields have resulted from BMP implementation in the Lovejoy Pond watershed, eutrophic conditions in the pond are expected to persist. However, reduced nutrient loading should serve to reduce the intensity and duration of algae blooms in the pond.

\section{CONCLUSIONS}

Comparison of total-phosphorus yields before and after BMP implementation provides clear evidence that phosphorus movement through the Johnson Brook study area was reduced. Reductions occurred in every season but spring. Phosphorus-yield data, normalized to account for herdsize changes, showed a consistent reduction in annual yields of about 25 percent upon implementation of the new management practices. In addition, median daily loads within comparable streamflow categories were between 26 and 90 percent less in the postimplementation period. These reductions are especially important considering the expected increase in potential phosphorus transport during the later year of the study when streamflows were 128 percent higher than the preimplementation period streamflows.

Effectiveness of individual practices could not be determined, because BMPs were implemented simultaneously. However, reduction in phosphorus concentrations in the summer and fall probably results from practices associated with crop planning and fencing off of the stream from the dairy herd. The reduction of phosphorus concentrations in the winter probably results from discontinued winter spreading of manure. Application of results from this study to other watersheds can be made with consideration of the following assumptions:

1. The relative composition of agricultural land must be similar. In the Johnson Brook watershed, dairy farming is the predominant type of agriculture. BMPs were tailored to land use with consideration for slopes, soils, and locations of activities relative to the stream.

2. The relative opportunity for improvement should be comparable. If farmers in the target watershed manage their fertilizers, manure, and soil before implementation of BMPs more efficiently than those in the Johnson Brook study area, then reductions of 25 percent using these BMPs may not be attainable. Conversely, if farming practices are less efficient before implementation of BMPs, then reductions greater than 25 percent may be attainable.

3. The BMPs are followed to the same extent as those in the Johnson Brook watershed. In this case, the BMPs were designed after consultation with the farmers in the watershed and the plans were fully implemented within a year of their development. 
The observed reductions in phosphorus yields are encouraging, but the resulting levels are still high enough to promote growth of algal blooms in Lovejoy Pond. In-pond restoration activities, such as nutrient inactivation through use of chemicals like aluminum sulfate and aluminum hydroxide or withdrawal of phosphorus-rich pond water, would have little effect on eutrophic conditions, because annual yields to the pond are still sufficient to sustain algal blooms. Phosphorus loading to the pond needs to be reduced further if in-pond restoration is to be effective on a long-term basis. Refinement of the BMPs to reduce overland runoff and increase infiltration of phosphorus-laden runoff water may be one means of accomplishing this. This does not mean that water-quality benefits are absent, however. The predicted reduction of in-pond phosphorus concentrations are expected to result in the lessening of the amount and duration of algal blooms once the pond reaches equilibrium with its newly-reduced phosphorus load.

The information in this report is expected to be of interest to water-resources managers, the agricultural community, and those interested in nonpoint source contamination. Because eutrophication is a major concern of lake managers, this study could benefit the planning of lake protection and restoration efforts. It could also serve as a first step toward refining BMPs to optimize their usefulness in similar areas and to help show that control of the nonpoint nutrient sources can improve water quality. 
LOCATION.--Lat $44^{\circ} 29^{\prime} 53^{\prime \prime}$, long $69^{\circ} 29^{\prime} 12^{\prime \prime}$, Rennebec County, Hydrologlc Unit 01030003, on right bank approximately $1.29 \mathrm{~km}$ downstream from Dutton Pond and approximately $1.80 \mathrm{~km}$ southwest of Albion.

DRAIRAGE AREA. $--7.56 \mathrm{~km}^{2}$.

PERIOD OP RECORD.--May 1980 through September 1984.

GAGE.--Water-stage recorder. Altitude of gage is $70.1 \mathrm{~m}$, from topographic map.

EXTREMES FOR PERIOD OF RECORD,--Maximum discharge $4.50 \mathrm{~m}^{3} / \mathrm{s}$ Apr. 25, 1983, gage helght $3.54 \mathrm{~m}$; minimum discharge, no flow many days during Aug. and Sept. 1980 and Aug., Sapt., Oct., and Nov. 1983.

1980 WATER YEAR

REMARKS. --Records good.

EXTREMES FOR CURRENT YEAR.-- Minimum discharge, no flow many days in Aug. and Sept.

DISCHARGE, IN CUBIC METERS PER SECOND, WATER YEAR OCTOBER 1979 TO SEPTEMBER 1980 MEAN VALUES

\begin{tabular}{|c|c|c|c|c|c|c|c|c|c|c|c|c|}
\hline DAY & OCT & NOV & DEC & JAN & FEB & MAR & APR & MAY & JUN & JUL & AUG & SEP \\
\hline 1 & -- & -- & -- & - & -- & -- & -- & -- & 0.027 & 0.013 & 0.005 & 0.000 \\
\hline 2 & -- & -- & -- & -- & -- & - & -- & -- & .026 & .011 & .003 & .000 \\
\hline 3 & -- & -- & -- & -- & -- & -- & -- & -- & .026 & .010 & .010 & .000 \\
\hline 4 & -- & -- & -- & -- & -- & -- & -- & -- & .031 & .009 & .009 & .000 \\
\hline 5 & -- & -- & -- & -- & -- & -- & -- & -- & .025 & .008 & .004 & .000 \\
\hline 6 & -- & -- & -- & -- & -- & - & -- & -- & .024 & .008 & .003 & .000 \\
\hline 7 & -- & -- & -- & -- & -- & - & -- & -- & .021 & .006 & .002 & .000 \\
\hline 8 & - & -- & -- & -- & -- & -- & -- & -- & .020 & .005 & .001 & .000 \\
\hline 9 & -- & -- & -- & - & -- & - & -- & -- & .018 & .007 & .001 & .000 \\
\hline 10 & - & - & -- & - & -- & -- & -- & -- & .017 & .005 & .000 & .000 \\
\hline 11 & -- & - & -- & - & -- & -- & -- & -- & .016 & .005 & .000 & .000 \\
\hline 12 & -- & -- & -- & - & -- & -- & - & 0.283 & .016 & .005 & .000 & .000 \\
\hline 13 & -- & -- & -- & -- & - & -- & -- & .269 & .015 & .005 & .000 & .000 \\
\hline 14 & -- & - & -- & -- & -- & -- & -- & .210 & .015 & .004 & .000 & .000 \\
\hline 15 & -- & -- & -- & -- & -- & -- & -- & .176 & .014 & .003 & .000 & .000 \\
\hline 16 & -- & -- & -- & -- & -- & -- & -- & .147 & .037 & .004 & .000 & .000 \\
\hline 17 & -- & -- & -- & -- & -- & -- & -- & .125 & .028 & .005 & .000 & .000 \\
\hline 18 & - & -- & -- & -- & -- & -- & -- & .110 & .017 & .003 & .000 & .000 \\
\hline 19 & - & -- & - & - & -- & -- & - & .108 & .013 & .002 & .000 & .000 \\
\hline 20 & -- & -- & -- & -- & -- & -- & -- & .093 & .013 & .002 & .000 & .000 \\
\hline 21 & -- & -- & -- & -- & -- & - & - & .085 & .057 & .002 & .000 & .000 \\
\hline 22 & -- & -- & - & -- & -- & - & - & .074 & .031 & .008 & .000 & .000 \\
\hline 23 & -- & -- & -- & -- & -- & -- & -- & .065 & .018 & .007 & .000 & .000 \\
\hline 24 & -- & -- & -- & -- & -- & -- & -- & .057 & .016 & .005 & .000 & .000 \\
\hline 25 & -- & -- & -- & -- & -- & -- & -- & .048 & .016 & .003 & .000 & .000 \\
\hline 26 & -- & -- & -- & -- & -- & -- & -- & .042 & .031 & .002 & .000 & .001 \\
\hline 27 & -- & -- & -- & - & - & -- & -- & .040 & .020 & .002 & .000 & .002 \\
\hline 28 & -- & -- & -- & -- & -- & -- & -- & .037 & .016 & .002 & .000 & .002 \\
\hline 29 & -- & -- & -- & -- & -- & -- & -- & .034 & .015 & .003 & .000 & .002 \\
\hline 30 & -- & -- & -- & -- & -- & -- & -- & .031 & .014 & .018 & .000 & .002 \\
\hline 31 & -- & -- & -- & -- & -- & -- & -- & .031 & - & .008 & .000 & - \\
\hline TOTAL & -- & -- & -- & -- & -- & -- & -- & - & .653 & .180 & .038 & .009 \\
\hline MEAN & -- & - & -- & -- & -- & -- & -- & -- & .022 & .006 & .001 & .000 \\
\hline MAX & - & -- & -- & -- & -- & - & -- & -- & .057 & .018 & .010 & .002 \\
\hline MIN & -- & -- & -- & -- & -- & -- & - & - & .013 & .002 & .000 & .000 \\
\hline CFSM & - & -- & -- & -- & -- & -- & -- & -- & .003 & .001 & .000 & .000 \\
\hline IN. & -- & -- & -- & -- & -- & -- & -- & - & 7.37 & 2.03 & .508 & .254 \\
\hline
\end{tabular}


Table 3.--Streamflow data for Johnson Brook at South Albion, Maine, 1980-84 water years--Continued

1981 WATER YEAR

REMARKS.--Records good except those for the winter period, which are fair.

EXTREMES FOR CURRENT YEAR.--Peak discharges above base $0.850 \mathrm{~m}^{3} / \mathrm{s}$ and maximum (*):

\begin{tabular}{|c|c|c|c|c|c|c|c|}
\hline Date & Time & $\begin{array}{c}\text { Discharge } \\
\left(\mathrm{m}^{3} / \mathrm{s}\right)\end{array}$ & $\begin{array}{c}\text { Gage helght } \\
(\mathrm{m})\end{array}$ & Date & Time & $\begin{array}{c}\text { Discharge } \\
\left(\mathrm{m}^{3} / \mathrm{s}\right)\end{array}$ & $\begin{array}{c}\text { Gage height } \\
(\mathrm{m})\end{array}$ \\
\hline Feb. & 1700 & * 1.13 & 3.03 & Jun 21 & 1930 & 0.878 & 2.91 \\
\hline
\end{tabular}

a Ice jam

DISCEARGE, IN CUBIC METERS PER SECOND, WATER YEAR OCTOBER 1980 TO SEPTEMBER 1981 MEAN VALUES

\begin{tabular}{|c|c|c|c|c|c|c|c|c|c|c|c|c|}
\hline DAY & OCT & NOV & DEC & JAN & FEB & MAR & APR & MAY & JUN & JUL & AUG & SEP \\
\hline 1 & 0.002 & 0.065 & 0.538 & 0.024 & 0.014 & 0.249 & 0.139 & 0.119 & 0.062 & 0.079 & 0.079 & 0.019 \\
\hline 2 & .002 & .057 & .453 & .023 & .425 & .235 & .312 & .113 & .054 & .065 & .068 & .017 \\
\hline 3 & .002 & .054 & .453 & .022 & .396 & .198 & .312 & .105 & .048 & .057 & .059 & .015 \\
\hline 4 & .031 & .048 & .396 & .021 & .255 & .176 & .312 & .093 & .045 & .045 & .045 & .014 \\
\hline 5 & .016 & .048 & .312 & .021 & .204 & .161 & .312 & .088 & .042 & .065 & .042 & .014 \\
\hline 6 & .010 & .042 & .263 & .020 & .176 & .150 & .368 & .085 & .040 & .076 & .042 & .012 \\
\hline 7 & .009 & .040 & .224 & .020 & .161 & .147 & .340 & .076 & .042 & .065 & .040 & .012 \\
\hline 8 & .009 & .048 & .181 & .019 & .147 & .142 & .340 & .065 & .034 & .057 & .034 & .010 \\
\hline 9 & .009 & .048 & .173 & .018 & .130 & .139 & .283 & .062 & .071 & .045 & .034 & .019 \\
\hline 10 & .008 & .045 & .147 & .018 & .125 & .133 & .249 & .057 & .062 & .037 & .031 & .015 \\
\hline 11 & .008 & .045 & .127 & .018 & .312 & .125 & .218 & .054 & .051 & .031 & .028 & .014 \\
\hline 12 & .022 & .045 & .099 & .017 & .680 & .116 & .187 & .042 & .048 & .027 & .026 & .013 \\
\hline 13 & .016 & .042 & .085 & .016 & .595 & .108 & .161 & .193 & .042 & .027 & .024 & .013 \\
\hline 14 & .014 & .042 & .079 & .016 & .510 & .105 & .150 & .133 & .037 & .031 & .022 & .012 \\
\hline 15 & .013 & .042 & .071 & .016 & .425 & .088 & .161 & .130 & .031 & .026 & .027 & .011 \\
\hline 16 & .013 & .042 & .062 & .016 & .312 & .093 & .142 & .312 & .031 & .022 & .167 & .010 \\
\hline 17 & .012 & .042 & .057 & .016 & .255 & .074 & .139 & .312 & .028 & .019 & .088 & .007 \\
\hline 18 & .019 & .042 & .051 & .015 & .241 & .074 & .142 & .312 & .024 & .018 & .091 & .007 \\
\hline 19 & .027 & .045 & .048 & .015 & .224 & .065 & .133 & .255 & .022 & .017 & .082 & .011 \\
\hline 20 & .022 & .045 & .045 & .015 & .249 & .062 & .125 & .210 & .024 & .015 & .071 & .014 \\
\hline 21 & .021 & .045 & .042 & .015 & .312 & .059 & .119 & .161 & .167 & .150 & .059 & .010 \\
\hline 22 & .019 & .048 & .040 & .015 & .340 & .054 & .110 & .139 & .255 & .147 & .048 & .014 \\
\hline 23 & .019 & .051 & .037 & .015 & .312 & .051 & .099 & .119 & .269 & .147 & .040 & .034 \\
\hline 24 & .018 & .057 & .034 & .015 & .275 & .048 & .116 & .093 & .241 & .130 & .037 & .042 \\
\hline 25 & .034 & .425 & .031 & .014 & .249 & .048 & .119 & .085 & .193 & .108 & .034 & .037 \\
\hline 26 & .110 & .340 & .031 & .014 & .241 & .048 & .113 & .076 & .224 & .082 & .034 & .031 \\
\hline 27 & .065 & .340 & .028 & .014 & . . .283 & .057 & .108 & .068 & .181 & .096 & .031 & .031 \\
\hline 28 & .076 & .312 & .028 & .014 & .255 & .079 & .096 & .062 & .150 & .076 & .026 & .037 \\
\hline 29 & .082 & .651 & .027 & .014 & -- & .091 & .105 & .057 & .127 & .125 & .023 & .031 \\
\hline 30 & .079 & .566 & .026 & .014 & -- & .105 & .133 & .057 & .096 & .108 & .022 & .028 \\
\hline 31 & .074 & -- & .025 & .014 & -- & .139 & -- & .071 & -- & .099 & .021 & -- \\
\hline TOTAL & .861 & 3.76 & 4.21 & .524 & 8.10 & 3.42 & 5.64 & 3.80 & 2.74 & 2.09 & 1.48 & .554 \\
\hline MEAN & .028 & .125 & .136 & .017 & .289 & .110 & .188 & .123 & .091 & .067 & .048 & .018 \\
\hline MAX & .110 & .651 & .538 & .024 & .680 & .249 & .368 & .312 & .269 & .150 & .167 & .042 \\
\hline MIN & .002 & .040 & .025 & .014 & .014 & .048 & .096 & .042 & .022 & .015 & .021 & .007 \\
\hline CFSM & .004 & .017 & .018 & .002 & .038 & .015 & .025 & .016 & .012 & .009 & .006 & .002 \\
\hline IN. & 9.91 & 42.93 & 48.26 & 6.10 & 92.46 & 39.12 & 64.52 & 43.43 & 31.24 & 23.88 & 16.76 & 6.35 \\
\hline
\end{tabular}

$\begin{array}{llllllllllll}\text { WTR YR } 1981 \text { TOTAL } 37.179 & \text { MEAN } 0.102 & \text { MAX } & 0.680 & \text { MIN } & 0.002 & \text { CMSK } & 0.013 & \text { MM } 424.9\end{array}$ 
Table 3.--Streamflow data for Johnson Brook at South Albion, Maine, 1980-84 water years--Continued.

1982 WATER YEAR

REMARKS.--Records good except those for the winter period, which are fair.

EXTREAES FOR CURRENT YEAR.--Peak discharges above base $0.850 \mathrm{~m}^{3} / \mathrm{s}$ and maximum (*):

\begin{tabular}{|c|c|c|c|c|c|c|c|}
\hline Date & Time & $\begin{array}{c}\text { Discharge } \\
\left(\mathrm{m}^{3} / \mathrm{s}\right)\end{array}$ & $\begin{array}{c}\text { Gage height } \\
\text { (m) }\end{array}$ & Date & Time & $\begin{array}{c}\text { Discharge } \\
\left(\mathrm{m}^{3} / \mathrm{s}\right)\end{array}$ & $\begin{array}{c}\text { Gage height } \\
\text { (m) }\end{array}$ \\
\hline Oct. 19 & 0315 & 0.878 & 2.90 & Apr. 1 & 1545 & $\star \quad 1.72$ & 3.08 \\
\hline Oct. 27 & 1345 & .991 & 2.95 & & & & \\
\hline
\end{tabular}

Minimum discharge, $0.002 \mathrm{~m}^{3} / \mathrm{s}$ Sept. 20, gage height, $2.40 \mathrm{~m}$.

DISCEARGE, IN CUBIC METERS PER SECOND, WATER YEAR OCTOBER 1981 TO SEPTEMBER 1982 MEAN VALUES

\begin{tabular}{|c|c|c|c|c|c|c|c|c|c|c|c|c|}
\hline DAY & OCT & NOV & DEC & JAN & FEB & MAR & APR & MAY & JUN & JUL & AUG & SEP \\
\hline 1 & 0.027 & 0.481 & 0.093 & 0.062 & 0.034 & 0.037 & 1.59 & 0.150 & 0.027 & 0.071 & 0.009 & 0.006 \\
\hline 2 & .027 & .396 & .249 & .062 & .034 & .037 & 1.53 & .133 & .241 & .065 & .008 & .007 \\
\hline 3 & .027 & .312 & .255 & .062 & .040 & .037 & 1.25 & .119 & .187 & .059 & .008 & .007 \\
\hline 4 & .026 & .263 & .255 & .074 & .071 & .037 & 1.39 & .110 & .181 & .054 & .007 & .007 \\
\hline 5 & .024 & .218 & .229 & .263 & .065 & .037 & 1.08 & .093 & .156 & .051 & .009 & .006 \\
\hline 6 & .024 & .227 & .204 & .227 & .059 & .040 & 0.821 & .082 & .125 & .045 & .008 & .005 \\
\hline 7 & .034 & .221 & .229 & .204 & .057 & .042 & .623 & .076 & .099 & .037 & .007 & .004 \\
\hline 8 & .034 & .204 & .218 & .178 & .054 & .099 & .538 & .068 & .082 & .031 & .011 & .004 \\
\hline 9 & .031 & .184 & .204 & .156 & .051 & .051 & .453 & .065 & .065 & .026 & .048 & .004 \\
\hline 10 & .028 & .159 & .181 & .136 & .051 & .048 & .425 & .065 & .059 & .023 & .040 & .003 \\
\hline 11 & .028 & .142 & .161 & .119 & .048 & .051 & .368 & .065 & .054 & .019 & .023 & .003 \\
\hline 12 & .027 & .130 & .147 & .108 & .048 & .051 & .396 & .062 & .048 & .015 & .021 & .003 \\
\hline 13 & .027 & .116 & .133 & .093 & .045 & .068 & .396 & .057 & .042 & .014 & .021 & .003 \\
\hline 14 & .026 & .110 & .113 & .085 & .045 & .110 & .510 & .054 & .042 & .012 & .018 & .003 \\
\hline 15 & .026 & .105 & .110 & .076 & .042 & .105 & .481 & .051 & .042 & .010 & .017 & .003 \\
\hline 16 & .024 & .099 & .150 & .068 & .042 & .105 & .510 & .048 & .040 & .009 & .015 & .005 \\
\hline 17 & .024 & .136 & .161 & .062 & .042 & .122 & .595 & .045 & .042 & .009 & .014 & .003 \\
\hline 18 & .026 & .215 & .142 & .057 & .042 & .167 & .708 & .042 & .042 & .008 & .014 & .003 \\
\hline 19 & .368 & .215 & .130 & .051 & .040 & .261 & .651 & .040 & .037 & .007 & .011 & .003 \\
\hline 20 & .210 & .218 & .116 & .048 & .040 & .312 & .595 & .059 & .037 & .010 & .010 & .002 \\
\hline 21 & .221 & .312 & .105 & .045 & .040 & .368 & .595 & .062 & .031 & .011 & .009 & .004 \\
\hline 22 & .195 & .275 & .099 & .042 & .040 & .340 & .510 & .057 & .027 & .010 & .008 & .006 \\
\hline 23 & .187 & .249 & .091 & .042 & .040 & .340 & .425 & .054 & .026 & .010 & .008 & .006 \\
\hline 24 & .538 & .210 & .088 & .040 & .040 & .312 & .368 & .048 & .026 & .008 & .017 & .005 \\
\hline 25 & .453 & .176 & .082 & .040 & .037 & .368 & .312 & .048 & .023 & .007 & .012 & .004 \\
\hline 26 & .481 & .150 & .079 & .040 & .037 & .510 & .263 & .042 & .026 & .006 & .014 & .004 \\
\hline 27 & .765 & .133 & .076 & .037 & .037 & .651 & .255 & .037 & .024 & .005 & .008 & .005 \\
\hline 28 & .906 & .130 & .074 & .037 & .037 & .651 & .229 & .031 & .021 & .009 & .007 & .007 \\
\hline 29 & .850 & .125 & .071 & .037 & -- & .623 & .198 & .027 & .071 & .031 & .007 & .006 \\
\hline 30 & .708 & .108 & .068 & .034 & -- & .595 & .173 & .027 & .099 & .011 & .006 & .005 \\
\hline 31 & .595 & -- & .065 & .034 & -- & .736 & - & .027 & -- & .010 & .006 & -- \\
\hline TOTAL & 6.97 & 6.02 & 4.38 & 2.62 & 1.26 & 7.31 & 18.24 & 1.94 & 2.02 & .693 & .421 & .137 \\
\hline MEAN & .225 & .201 & .141 & .084 & .045 & .236 & .608 & .063 & .067 & .022 & .014 & .005 \\
\hline MAX & .906 & .481 & .255 & .263 & .071 & .736 & 1.59 & .150 & .241 & .071 & .048 & .007 \\
\hline MIN & .024 & .099 & .065 & .034 & .034 & .037 & .173 & .027 & .021 & .005 & .006 & .002 \\
\hline CMSK & .030 & .027 & .019 & .011 & .006 & .031 & .080 & .008 & .009 & .003 & .002 & .001 \\
\hline $\mathbf{M M}$ & 79.50 & 68.83 & 50.04 & 29.97 & 14.48 & 83.57 & 208.3 & 22.35 & 23.11 & 7.87 & 4.83 & 1.52 \\
\hline
\end{tabular}

$\begin{array}{lllllllllll}\text { CAL YR } 1981 & \text { TOTAL } & 45.722 & \text { MEAN } 0.125 & \text { MAX } & 0.906 & \text { MIN } & 0.007 & \text { CMSK } & 0.017 & \text { MM } 522.2\end{array}$

WTR YR 1982 TOTAL 52.011 MEAN .142 MAX $1.59 \quad$ MIN $.002 \quad$ CMSK $.019 \quad$ MM 594.1 
Table 3.--Streamflow data for Johnson Brook at South Albion, Maine, 1980-84 water years--Continued.

1983 WATER YEAR

REMARKS. - Records fair.

EXTREMES FOR CURRENT YEAR.--Peak discharges above base $0.850 \mathrm{~m}^{3} / \mathrm{s}$ and maximum (*):

\begin{tabular}{|c|c|c|c|c|c|c|c|}
\hline Date & TIme & $\begin{array}{c}\text { Discherse } \\
\left(m^{3} / s\right)\end{array}$ & $\begin{array}{c}\text { Gage helght } \\
\text { (m) }\end{array}$ & Date & Time & $\begin{array}{c}\text { D1scharge } \\
\left(m^{3} / s\right)\end{array}$ & $\begin{array}{c}\text { Gage helght } \\
\text { (m) }\end{array}$ \\
\hline Feb. 03 & 1200 & 1.27 & 3.02 & Apr. 17 & 1715 & 1.56 & 3.08 \\
\hline Mar. 12 & 1700 & 1.02 & 2.96 & Apr. 25 & 0145 & $\star \quad 4.50$ & 3.54 \\
\hline Mar. 22 & 0100 & 1.56 & 3.08 & & & & \\
\hline
\end{tabular}

Minimum discharge, no flow many days during Aug. and Sept.

DISCHARGE, IN CUBIC METERS PER SECOND, WATER YEAR OCTOBER 1982 TO SEPTEMBER 1983 MEAN VALUES

\begin{tabular}{|c|c|c|c|c|c|c|c|c|c|c|c|c|}
\hline DAY & OCT & NOV & DEC & JAN & FEB & MAR & APR & MAY & JUN & JUL & AUG & SEP \\
\hline 1 & 0.003 & 0.007 & 0.048 & 0.079 & 0.057 & 0.040 & 0.227 & 0.595 & 0.368 & 0.008 & 0.002 & 0.001 \\
\hline 2 & .003 & .007 & .048 & .071 & .057 & .142 & .207 & .566 & .340 & .008 & .003 & .000 \\
\hline 3 & .003 & .008 & .048 & .062 & .481 & .425 & .187 & .566 & .275 & .008 & .003 & .000 \\
\hline 4 & .003 & .006 & .051 & .054 & .453 & .340 & .263 & .510 & .263 & .008 & .002 & .000 \\
\hline 5 & .002 & .013 & .048 & .051 & .425 & .340 & .235 & .481 & .249 & .008 & .002 & .000 \\
\hline 6 & .002 & .011 & .051 & .051 & .340 & .312 & .227 & .425 & .224 & .018 & .002 & .000 \\
\hline 7 & .003 & .008 & .054 & .051 & .224 & .275 & .210 & .396 & .201 & .015 & .002 & .000 \\
\hline 8 & .005 & .007 & .051 & .048 & .159 & .244 & .204 & .340 & .181 & .012 & .001 & .000 \\
\hline 9 & .004 & .007 & .048 & .042 & .127 & .215 & .190 & .283 & .150 & .010 & .002 & .000 \\
\hline 10 & .004 & .006 & .042 & .037 & .108 & .283 & .178 & .249 & .122 & .009 & .001 & .000 \\
\hline 11 & .004 & .006 & .028 & .238 & .093 & .453 & .425 & .227 & .096 & .008 & .000 & .000 \\
\hline 12 & .003 & .006 & .020 & .210 & .085 & .765 & .425 & .204 & .076 & .007 & .014 & .000 \\
\hline 13 & .003 & .088 & .013 & .176 & .074 & .850 & .368 & .190 & .065 & .016 & .012 & .000 \\
\hline 14 & .007 & .054 & .012 & .144 & .068 & .736 & .312 & .184 & .059 & .012 & .007 & .000 \\
\hline 15 & .007 & .068 & .012 & .122 & .065 & .595 & .283 & .173 & .051 & .010 & .005 & .000 \\
\hline 16 & .005 & .079 & .040 & .108 & .062 & .566 & .255 & .167 & .045 & .009 & .004 & .000 \\
\hline 17 & .004 & .076 & .079 & .093 & .057 & .510 & 1.02 & .150 & .042 & .008 & .003 & .000 \\
\hline 18 & .004 & .071 & .054 & .082 & .057 & .453 & 1.02 & .130 & .037 & .008 & .002 & .000 \\
\hline 19 & .004 & .062 & .040 & .071 & .057 & .538 & .878 & .108 & .037 & .007 & .000 & .000 \\
\hline 20 & .004 & .059 & .045 & .065 & .054 & .793 & .708 & .125 & .031 & .006 & .000 & .000 \\
\hline 21 & .005 & .054 & .048 & .057 & .051 & .708 & .566 & .136 & .026 & .005 & .000 & .000 \\
\hline 22 & .005 & .054 & .048 & .054 & .048 & 1.16 & .481 & .122 & .022 & .010 & .000 & .001 \\
\hline 23 & .005 & .051 & .040 & .054 & .048 & .906 & .396 & .139 & .018 & .010 & .000 & .002 \\
\hline 24 & .004 & .054 & .040 & .119 & .045 & .708 & .708 & .142 & .016 & .007 & .000 & .000 \\
\hline 25 & .004 & .054 & .042 & .102 & .045 & .510 & 2.29 & .136 & .013 & .007 & .000 & .000 \\
\hline 26 & .004 & .048 & .110 & .088 & .042 & .396 & 1.98 & .122 & .012 & .006 & .000 & .000 \\
\hline 27 & .004 & .045 & .074 & .074 & .040 & .340 & 1.67 & .130 & .012 & .005 & .000 & .000 \\
\hline 28 & .005 & .040 & .082 & .068 & .040 & .340 & 1.16 & .244 & .011 & .003 & .000 & .000 \\
\hline 29 & .005 & .042 & .130 & .062 & -- & .312 & .850 & .204 & .010 & .003 & .000 & .000 \\
\hline 30 & .003 & .051 & .110 & .059 & -- & .278 & .680 & .263 & .010 & .003 & .000 & .000 \\
\hline 31 & .006 & -- & .091 & .059 & -- & .255 & -- & .425 & -- & .003 & .000 & - \\
\hline TOTAL & .127 & 1.14 & 1.64 & 2.65 & 3.86 & 14.79 & 18.60 & 8.13 & 3.06 & .257 & .067 & .004 \\
\hline MEAN & .004 & .038 & .053 & .085 & .138 & .477 & .620 & .262 & .102 & .008 & .002 & .000 \\
\hline MAX & .007 & .088 & .130 & .238 & .481 & 1.16 & 2.29 & .595 & .368 & .018 & .014 & .002 \\
\hline MIN & .002 & .006 & .012 & .037 & .040 & .040 & .178 & .108 & .010 & .003 & .000 & .000 \\
\hline CMSK & .001 & .005 & .007 & .011 & .018 & .063 & .082 & .035 & .013 & .001 & .000 & .000 \\
\hline$M$ & 1.52 & 12.95 & 18.80 & 30.23 & 39.62 & 168.9 & 212.6 & 92.96 & 35.05 & 3.05 & .762 & .000 \\
\hline
\end{tabular}

CAL YR 1982 TOTAL 37.558 MEAN 0.103 MAX 1.59 MIN $0.002 \quad$ CMSR $0.014 \quad$ MM 429.0

WTR YR 1983 TOTAL 54.255 MEAN .148 MAX 2.29 MIN .000 
REMARKS.--Records good except those for the winter period, which are fair.

EXTREMES FOR CURRENT YEAR.--Peak discharges above base $0.850 \mathrm{~m}^{3} / \mathrm{s}$ and maximum (*):

\begin{tabular}{|c|c|c|c|c|c|c|c|}
\hline Date & Time & $\begin{array}{c}\text { Discharge } \\
\left(m^{3} / s\right)\end{array}$ & $\begin{array}{c}\text { Gage helght } \\
\text { (m) }\end{array}$ & Date & Time & $\begin{array}{c}\text { Disçharge } \\
\left(\mathrm{m}^{3} / \mathrm{s}\right)\end{array}$ & $\begin{array}{c}\text { Gage heitht } \\
(m)\end{array}$ \\
\hline Nov. 25 & 1500 & 2.04 & 3.26 & Feb. 15 & 1430 & 1.33 & 3.10 \\
\hline Dec. 07 & 0200 & 1.30 & 3.09 & Mar. 22 & 1715 & 0.878 & 2.99 \\
\hline Dec. 13 & 2330 & 1.87 & 3.22 & Apr. 06 & 0230 & 2.32 & 3.31 \\
\hline Dec. 29 & 0030 & 0.850 & 2.98 & June 02 & 1345 & * 3.12 & 3.44 \\
\hline
\end{tabular}

Minimum discharge, no flow many days during Oct. and Nov.

DISCEARGE, IN CUBIC METERS PER SECOND, WATER YEAR OCTOBER 1983 TO SEPTEMBER 1984

MEAN VALUES

\begin{tabular}{|c|c|c|c|c|c|c|c|c|c|c|c|c|}
\hline DAY & OCT & Nov & DEC & JAN & FEB & MAR & APR & MAY & JUN & JUL & AUG & SEP \\
\hline 1 & 0.000 & 0.000 & 0.510 & 0.147 & 0.034 & 0.396 & 0.312 & 0.198 & 1.98 & 0.057 & 0.004 & 0.002 \\
\hline 2 & .000 & .000 & .396 & .127 & .031 & .340 & .396 & .173 & 2.24 & .048 & .004 & .001 \\
\hline 3 & .000 & .000 & .312 & .122 & .031 & .283 & .453 & .147 & 1.90 & .040 & .003 & .001 \\
\hline 4 & .000 & .001 & .280 & .110 & .340 & .244 & .481 & .215 & 1.47 & .034 & .002 & .001 \\
\hline 5 & .000 & .027 & .263 & .105 & .263 & .190 & .680 & .244 & 1.10 & .034 & .002 & .001 \\
\hline 6 & .000 & .031 & .238 & .099 & .204 & .170 & 1.76 & .212 & 0.821 & .048 & .003 & .001 \\
\hline 7 & .000 & .015 & .765 & .096 & .176 & .147 & 1.61 & .187 & .708 & .057 & .004 & .001 \\
\hline 8 & .000 & .012 & .595 & .091 & .161 & .119 & 1.39 & .167 & .651 & .079 & .006 & .001 \\
\hline 9 & .000 & .011 & .481 & .076 & .130 & .102 & 1.05 & .181 & .538 & .071 & .003 & .001 \\
\hline 10 & .000 & .011 & .396 & .068 & .113 & .091 & .793 & .170 & .368 & .057 & .003 & .001 \\
\hline 11 & .000 & .048 & .312 & .062 & .133 & .079 & .651 & .144 & .241 & .045 & .003 & .008 \\
\hline 12 & .000 & .048 & .278 & .054 & .187 & .071 & .566 & .312 & .161 & .042 & .004 & .026 \\
\hline 13 & .009 & .048 & 1.08 & .051 & .229 & .062 & .481 & .368 & .119 & .037 & .003 & .008 \\
\hline 14 & .008 & .042 & 1.59 & .048 & .201 & .037 & .453 & .453 & .096 & .034 & .003 & .007 \\
\hline 15 & .002 & .042 & 1.53 & .045 & .566 & .037 & .396 & .453 & .193 & .031 & .004 & .007 \\
\hline 16 & .001 & .142 & 1.27 & .045 & .736 & .042 & .425 & .396 & .142 & .028 & .003 & .007 \\
\hline 17 & .000 & .187 & .963 & .042 & .651 & .481 & .453 & .340 & .085 & .026 & .002 & .005 \\
\hline 18 & .000 & .170 & .736 & .042 & .538 & .283 & .425 & .283 & .051 & .023 & .002 & .004 \\
\hline 19 & .000 & .161 & .538 & .040 & .453 & .283 & .425 & .272 & .062 & .023 & .002 & .003 \\
\hline 20 & .000 & .142 & .368 & .040 & .425 & .425 & .368 & .235 & .040 & .017 & .024 & .003 \\
\hline 21 & .000 & .269 & .283 & .040 & .396 & .396 & .340 & .187 & .037 & .014 & .012 & .003 \\
\hline 22 & .000 & .283 & .241 & .037 & .340 & .736 & .312 & .142 & .034 & .011 & .006 & .002 \\
\hline 23 & .000 & .283 & .204 & .037 & .283 & .878 & .283 & .093 & .034 & .010 & .006 & .002 \\
\hline 24 & .000 & .278 & .173 & .102 & .340 & .821 & .283 & .091 & .031 & .009 & .016 & .002 \\
\hline 25 & .001 & 1.22 & .139 & .255 & .396 & .736 & .312 & .059 & .059 & .008 & .008 & .002 \\
\hline 26 & .001 & 1.22 & .122 & .113 & .680 & .623 & .283 & .040 & .125 & .007 & .005 & .001 \\
\hline 27 & .001 & 1.13 & .105 & .074 & .595 & .510 & .283 & .042 & .167 & .006 & .003 & .001 \\
\hline 28 & .000 & .878 & .116 & .065 & .481 & .425 & .272 & .031 & .122 & .010 & .003 & .001 \\
\hline 29 & .000 & .736 & .340 & .051 & .453 & .368 & .255 & .252 & .088 & .008 & .002 & .001 \\
\hline 30 & .000 & .623 & .193 & .048 & -- & .312 & .227 & .708 & .068 & .006 & .002 & .001 \\
\hline 31 & .000 & -- & .167 & .042 & -- & .283 & -- & 1.56 & -- & .005 & .002 & -- \\
\hline TOTAL & .023 & 8.06 & 14.98 & 2.37 & 9.57 & 9.97 & 16.42 & 8.36 & 13.73 & .926 & .149 & .105 \\
\hline MEAN & .001 & .269 & .483 & .077 & .330 & .322 & .547 & .270 & .458 & .030 & .005 & .004 \\
\hline MAX & .009 & 1.22 & 1.59 & .255 & .736 & .878 & 1.76 & 1.56 & 2.24 & .079 & .024 & .026 \\
\hline MIN & .000 & .000 & .105 & .037 & .031 & .037 & .227 & .031 & .031 & .005 & .002 & .001 \\
\hline CMSK & .000 & .036 & .064 & .010 & .044 & .043 & .072 & .036 & .061 & .004 & .001 & .001 \\
\hline $\mathbf{M M}$ & .254 & 91.93 & 171.2 & 27.18 & 109.2 & 114.0 & 187.5 & 95.50 & 157.0 & 10.67 & 1.78 & 1.27 \\
\hline
\end{tabular}

CAL YR 1983 TOTAL 74.085 MEAN $0.203 \quad$ MAX 2.29 $\quad$ MIN $0.000 \quad$ CMSK $0.027 \quad$ MM 846.6

WTR YR 1984 TOTAL 84.662 MEAN .231 MAX 2.24 MIN .000 
Table 6.-- Water-qual1ty data from Johnson Brook at South Albion, Maine, Ocţober 1981 to September 1984 $\left[\mathrm{m}^{3} / \mathrm{s}\right.$, cublc meter per second, $\mathrm{mg} / \mathrm{L}$, mll1igrams per liter; a dash Indlcates no data]

\begin{tabular}{|c|c|c|c|c|c|c|c|c|c|c|c|c|}
\hline & Date & Tlme & $\begin{array}{l}\text { Stream- } \\
\text { flow, } \\
\text { Instan- } \\
\text { taneous } \\
\left(\mathrm{m}^{3} / \mathrm{s}\right)\end{array}$ & $\begin{array}{l}\text { Phos- } \\
\text { phorus, } \\
\text { total, } \\
\text { EWI-ETR } 1 \\
\text { samples } \\
\text { (mg/L) }\end{array}$ & $\begin{array}{l}\text { Phos- } \\
\text { phorus, } \\
\text { total, } \\
\text { pumplng } \\
\text { sampler } \\
\text { (mg/L) }\end{array}$ & $\begin{array}{l}\text { Sed 1- } \\
\text { ment, } \\
\text { sus- } \\
\text { pended } \\
(\mathrm{mg} / \mathrm{L})\end{array}$ & Date & Time & $\begin{array}{l}\text { Stream- } \\
\text { flow, } \\
\text { Instan- } \\
\text { taneous } \\
\left(\mathrm{m}^{3} / \mathrm{s}\right)\end{array}$ & $\begin{array}{l}\text { Phos- } \\
\text { phorus, } \\
\text { total, } \\
\text { BUI-ETR1 } \\
\text { samples } \\
\text { (ms/L) }\end{array}$ & $\begin{array}{l}\text { Phos- } \\
\text { phorus, } \\
\text { total, } \\
\text { pumplns } \\
\text { samplex } \\
\text { (moll) }\end{array}$ & $\begin{array}{l}\text { Sed1- } \\
\text { ment, } \\
\text { sus- } \\
\text { pended } \\
(\operatorname{mg} / L)\end{array}$ \\
\hline \multirow[t]{44}{*}{ Oct } & 1981 & & & & & & Nov 1981 & & & & & \\
\hline & $01 \ldots$ & $16: 10$ & 0.026 & 0.056 & -- & 2 & $18 \ldots$ & $16: 45$ & 0.269 & 0.043 & -- & -- \\
\hline & $04 \ldots$ & $11: 30$ & .026 & 0.032 & -- & -- & $19 \ldots$ & -- & -- & 0.11 & -- & -- \\
\hline & $07 \ldots$ & $10: 00$ & .037 & 0.044 & -- & 5 & $20 \ldots$ & $16: 15$ & .218 & 0.033 & -- & -- \\
\hline & $08 \ldots$ & $09: 15$ & .031 & 0.04 & -- & 2 & $21 \ldots$ & $07: 15$ & .368 & 0.17 & -- & -- \\
\hline & $09 \ldots$ & $12: 00$ & .031 & 0.041 & -- & 2 & $22 \ldots$ & $09: 30$ & .275 & 0.037 & -- & -- \\
\hline & $14 \ldots$ & $11: 30$ & .026 & -- & -- & 3 & $23 \ldots$ & -- & -- & 0.028 & -- & -- \\
\hline & $17 \ldots$ & $19: 15$ & .024 & -- & 0.08 & -- & Dec 1981 & & & & & \\
\hline & $18 \ldots$ & $11: 15$ & .023 & -- & 1.50 & -- & $02 \ldots$ & $10: 00$ & -- & 0.25 & -- & -- \\
\hline & $18 \ldots$ & $19: 15$ & .023 & -- & 0.44 & -- & $02 \ldots$ & $16: 15$ & .312 & 0.14 & -- & -- \\
\hline & $19 \ldots$ & $10: 45$ & .340 & 0.37 & -- & 20 & $03 \ldots$ & $10: 30$ & -- & 0.041 & -- & -- \\
\hline & $19 \ldots$ & $11: 15$ & .312 & -- & 0.22 & -- & $09 \ldots$ & $15: 30$ & -- & 0.022 & -- & -- \\
\hline & $19 \ldots$ & $14: 30$ & .224 & 0.29 & -- & 19 & $14 \ldots$ & $15: 30$ & -- & 0.032 & -- & -- \\
\hline & $20 \ldots$ & $13: 30$ & .218 & -- & -- & 5 & $18 \ldots$ & $14: 45$ & -- & 0.027 & -- & -- \\
\hline & $21 \ldots$ & $10: 45$ & .224 & -- & -- & 5 & $30 \ldots$ & $10: 30$ & -- & 0.035 & -- & -- \\
\hline & $21 \ldots$ & $10: 50$ & .224 & -- & -- & 22 & Jan 1982 & & & & & \\
\hline & $22 \ldots$ & $22: 45$ & .198 & -- & 0.047 & -- & $05 \ldots$ & $12: 00$ & -- & 0.22 & -- & -- \\
\hline & $23 \ldots$ & $08: 15$ & .176 & 0.042 & -- & 4 & $06 \ldots$ & $10: 30$ & .227 & 0.15 & -- & -- \\
\hline & $23 \ldots$ & $10: 50$ & .173 & -- & 0.054 & - & $08 \ldots$ & $11: 30$ & -- & 0.042 & -- & -- \\
\hline & $23 \ldots$ & $23: 15$ & .283 & -- & 0.13 & 15 & $21 \ldots$ & $15: 00$ & -- & 0.035 & -- & -- \\
\hline & $24 \ldots$ & $05: 15$ & .595 & -- & 0.33 & 27 & Feb 1982 & & & & & \\
\hline & $24 \ldots$ & $07: 15$ & .793 & 0.41 & -- & 28 & $02 \ldots$ & $13: 00$ & .037 & 0.028 & -- & 3 \\
\hline & $24 \ldots$ & $08: 00$ & .765 & 0.41 & -- & 23 & Mar 1982 & & & & & \\
\hline & $24 \ldots$ & $18: 15$ & .453 & 0.11 & -- & 8 & $04 \ldots$ & $15: 00$ & .037 & -- & -- & 2 \\
\hline & $25 \ldots$ & $10: 15$ & .453 & -- & 0.15 & 14 & $08 \ldots$ & $13: 30$ & .099 & 0.12 & -- & 33 \\
\hline & $25 \ldots$ & $16: 45$ & .453 & 0.053 & -- & 4 & $12 \ldots$ & $15: 45$ & .059 & 0.61 & -- & 26 \\
\hline & $26 \ldots$ & $11: 15$ & .453 & -- & 0.09 & 3 & $13 \ldots$ & $15: 15$ & .068 & 0.30 & -- & 17 \\
\hline & $26 \ldots$ & $11: 30$ & .453 & 0.08 & -- & 5 & $16 \ldots$ & $15: 15$ & .110 & 0.19 & -- & -- \\
\hline & $26 \ldots$ & $16: 30$ & .481 & 0.052 & -- & 5 & $19 \ldots$ & $14: 00$ & .283 & 0.111 & -- & 11 \\
\hline & $26 \ldots$ & $22: 35$ & .510 & -- & 0.065 & 10 & $23 \ldots$ & $10: 30$ & .312 & 0.038 & -- & 2 \\
\hline & $27 \ldots$ & $04: 35$ & .510 & -- & 0.15 & 20 & $26 \ldots$ & $07: 45$ & .425 & 0.056 & -- & 3 \\
\hline & $27 \ldots$ & $06: 45$ & .736 & 0.38 & - & 29 & $26 \ldots$ & $13: 15$ & .481 & 0.071 & -- & 5 \\
\hline & $27 \ldots$ & $10: 45$ & .850 & -- & 0.28 & 24 & $26 \ldots$ & $13: 16$ & .481 & -- & 0.077 & 8 \\
\hline & $27 \ldots$ & $13: 30$ & .991 & 0.22 & -- & 16 & $26 \ldots$ & $16: 30$ & .623 & 0.15 & -- & 20 \\
\hline & $27 \ldots$ & $16: 45$ & .878 & -- & 0.18 & 14 & $26 \ldots$ & $19: 15$ & .708 & -- & 0.25 & 20 \\
\hline & $27 \ldots$ & $22: 35$ & .821 & -- & 0.13 & 10 & $27 \ldots$ & $01: 15$ & .680 & -- & 0.16 & 12 \\
\hline & $28 \ldots$ & $04: 35$ & .850 & -- & 0.11 & 7 & $27 \ldots$ & $07: 15$ & .651 & -- & 0.09 & 10 \\
\hline & $28 \ldots$ & $06: 00$ & .850 & 0.08 & -- & 7 & $27 \ldots$ & $13: 15$ & .680 & -- & 0.08 & 5 \\
\hline & $28 \ldots$ & $10: 35$ & .963 & -- & 0.11 & -- & $30 \ldots$ & $15: 15$ & .623 & 0.061 & -- & 5 \\
\hline & $28 \ldots$ & $10: 40$ & .963 & 0.11 & -- & 8 & $31 \ldots$ & $17: 40$ & .850 & 0.15 & -- & 15 \\
\hline & $28 \ldots$ & $22: 35$ & .878 & -- & 0.07 & -- & $31 \ldots$ & $17: 45$ & .850 & -- & 0.17 & 17 \\
\hline & $29 \ldots$ & $10: 20$ & .850 & -- & 0.072 & 3 & $31 \ldots$ & $20: 15$ & .991 & 0.17 & -- & 23 \\
\hline & $29 \ldots$ & $10: 25$ & .850 & 0.051 & -- & 6 & $31 \ldots$ & $20: 45$ & 1.02 & -- & 0.24 & 30 \\
\hline & $30 \ldots$ & $14: 45$ & .708 & 0.045 & -- & 3 & $31 \ldots$ & $23: 45$ & 1.19 & -- & 0.22 & 38 \\
\hline \multirow[t]{10}{*}{ Nov } & 1981 & & & & & & Apr 1982 & & & & & \\
\hline & $01 \ldots$ & $10: 15$ & .538 & 0.048 & -- & 15 & $01 \ldots$ & $02: 45$ & 1.53 & -- & 0.21 & 23 \\
\hline & $05 \ldots$ & $15: 15$ & .210 & 0.031 & -- & 2 & $01 \ldots$ & $05: 55^{\prime}$ & 1.16 & 0.10 & -- & 9 \\
\hline & $06 \ldots$ & $15: 45$ & .255 & 0.09 & -- & -- & $01 \ldots$ & $05: 56$ & 1.42 & -- & 0.13 & 14 \\
\hline & $06 \ldots$ & $21: 45$ & .249 & -- & 0.057 & 5 & $01 \ldots$ & $15: 46$ & 1.76 & -- & 0.11 & 15 \\
\hline & $07 \ldots$ & $03: 45$ & .224 & -- & 0.039 & 4 & $02 \ldots$ & $11: 15$ & 1.53 & 0.029 & -- & 4 \\
\hline & $07 \ldots$ & $09: 45$ & .218 & -- & 0.044 & 6 & $02 \ldots$ & $11: 16$ & 1.53 & -- & 0.044 & 7 \\
\hline & $15 \ldots$ & $15: 30$ & .105 & 0.029 & -- & 3 & $03 \ldots$ & $11: 40$ & 1.19 & -- & 0.031 & 7 \\
\hline & $16 \ldots$ & $15: 45$ & .099 & 0.032 & -- & -- & $03 \ldots$ & $11: 45$ & 1.19 & 0.03 & -- & 2 \\
\hline & $18 \ldots$ & $11: 15$ & .269 & 0.24 & -- & -- & $03 \ldots$ & $14: 40$ & 1.19 & - & 0.035 & 3 \\
\hline
\end{tabular}




\begin{tabular}{|c|c|c|c|c|c|c|c|c|c|c|c|c|}
\hline & Date & Time & $\begin{array}{l}\text { Stream- } \\
\text { flow, } \\
\text { Instan- } \\
\text { taneous } \\
\left(\mathrm{m}^{3} / \mathrm{s}\right)\end{array}$ & $\begin{array}{l}\text { Phos- } \\
\text { phorus, } \\
\text { total, } \\
\text { EWI-EIR } 1 \\
\text { samples } \\
\text { (mg/L) }\end{array}$ & $\begin{array}{l}\text { Phos- } \\
\text { phorus, } \\
\text { total, } \\
\text { pump ing } \\
\text { sampler } \\
\text { (mg/L) }\end{array}$ & $\begin{array}{l}\text { Sed1- } \\
\text { ment, } \\
\text { sus - } \\
\text { pended } \\
(\mathrm{mg} / \mathrm{L})\end{array}$ & Date & Time & $\begin{array}{l}\text { Stream- } \\
\text { flow, } \\
\text { instan- } \\
\text { taneous } \\
\left(\mathrm{m}^{3} / \mathrm{s}\right)\end{array}$ & $\begin{array}{l}\text { Phos- } \\
\text { phorus, } \\
\text { total, } \\
\text { ENI-EIR } 1 \\
\text { samples } \\
\text { (mg/L) }\end{array}$ & $\begin{array}{l}\text { Phos- } \\
\text { phorus, } \\
\text { total, } \\
\text { pumping } \\
\text { sampler } \\
\text { (mg/L) }\end{array}$ & $\begin{array}{l}\text { Sed I- } \\
\text { ment, } \\
\text { sus - } \\
\text { pended } \\
\text { (mg/L) }\end{array}$ \\
\hline \multirow[t]{48}{*}{ Apr 1} & 1982 & & & & & & Jun 1982 & & & & & \\
\hline & $03 \ldots$ & $17: 40$ & 1.13 & -- & 0.034 & 2 & $02 \ldots$ & $08: 30$ & 0.023 & -- & 0.15 & 28 \\
\hline & $03 \ldots$ & $20: 40$ & 1.10 & -- & 0.072 & 4 & $02 \ldots$ & $08: 31$ & .023 & 0.13 & -- & 17 \\
\hline & $03 \ldots$ & $23: 40$ & 1.47 & 0.14 & -- & 43 & $02 \ldots$ & $10: 30$ & .054 & - & 0.94 & 178 \\
\hline & $03 \ldots$ & $23: 41$ & 1.47 & -- & 0.144 & 16 & $02 \ldots$ & $11: 30$ & .102 & -- & 0.80 & 181 \\
\hline & $04 \ldots$ & $02: 40$ & 1.47 & 0.09 & -- & 9 & $02 \ldots$ & $11: 31$ & .102 & 0.88 & -- & 172 \\
\hline & $04 \ldots$ & $02: 41$ & 1.47 & -- & 0.035 & 9 & $02 \ldots$ & $12: 30$ & .235 & - & 1.04 & 434 \\
\hline & $04 \ldots$ & $05: 40$ & 1.53 & -- & 0.077 & 5 & $02 \ldots$ & $13: 30$ & .456 & -- & 0.64 & 209 \\
\hline & $04 \ldots$ & $08: 40$ & 1.53 & -- & 0.079 & 4 & $02 \ldots$ & $14: 30$ & .566 & -- & 0.50 & 122 \\
\hline & $04 \ldots$ & $11: 05$ & 1.44 & 0.062 & -- & 4 & $02 \ldots$ & $15: 30$ & .595 & -- & 0.41 & 65 \\
\hline & $04 \ldots$ & $18: 00$ & 1.33 & -- & 0.041 & 3 & $02 \ldots$ & $16: 30$ & .566 & -- & 0.46 & 66 \\
\hline & $04 \ldots$ & $24: 00$ & 1.22 & -- & 0.038 & 3 & $02 \ldots$ & $16: 31$ & .566 & 0.47 & -- & 62 \\
\hline & $05 \ldots$ & $06: 00$ & 1.13 & -- & 0.036 & 3 & $03 \ldots$ & $08: 30$ & .176 & - & 0.13 & 26 \\
\hline & $05 \ldots$ & $12: 00$ & 1.08 & -- & 0.035 & 6 & $03 \ldots$ & $08: 31$ & .176 & 0.13 & -- & 15 \\
\hline & $05 \ldots$ & $13: 45$ & 1.08 & 0.029 & -- & 4 & $14 \ldots$ & $08: 35$ & .042 & 0.06 & -- & 6 \\
\hline & $06 \ldots$ & $01: 55$ & 0.935 & -- & -- & 3 & $17 \ldots$ & $15: 15$ & .042 & 0.046 & -- & 6 \\
\hline & $06 \ldots$ & $01: 56$ & .935 & -- & -- & 3 & $25 \ldots$ & $13: 00$ & .023 & 0.051 & -- & -- \\
\hline & $06 \ldots$ & $07: 45$ & .878 & 0.027 & -- & 1 & $29 \ldots$ & $08: 00$ & .026 & 0.07 & -- & 9 \\
\hline & $06 \ldots$ & $13: 55$ & .821 & -- & -- & 4 & $29 \ldots$ & $08: 01$ & .026 & - & 0.054 & 8 \\
\hline & $07 \ldots$ & $01: 55$ & .651 & -- & 0.036 & 8 & $29 \ldots$ & $10: 00$ & .024 & -- & 0.069 & 7 \\
\hline & $07 \ldots$ & $13: 55$ & .680 & -- & 0.12 & 59 & $29 \ldots$ & $12: 00$ & .024 & -- & 0.064 & 8 \\
\hline & $08 \ldots$ & $01: 55$ & .566 & -- & 0.036 & 14 & $29 \ldots$ & $13: 30$ & .051 & 0.10 & -- & 27 \\
\hline & $08 \ldots$ & $13: 55$ & .538 & -- & 0.048 & 23 & $29 \ldots$ & $14: 00$ & .071 & -- & 0.41 & 176 \\
\hline & $09 \ldots$ & $01: 55$ & .481 & -- & 0.042 & 9 & $29 \ldots$ & $16: 00$ & .110 & -- & 0.16 & 59 \\
\hline & $09 \ldots$ & $12: 15$ & .453 & -- & 0.033 & 7 & $29, \ldots$ & $18: 00$ & .102 & -- & 0.14 & 30 \\
\hline & $09 \ldots$ & $12: 16$ & .453 & 0.036 & -- & 3 & $29 \ldots$ & $20: 00$ & .113 & -- & 0.17 & 32 \\
\hline & $10 \ldots$ & $00: 40$ & .453 & -- & 0.04 & 9 & $29 \ldots$ & $21: 00$ & .142 & 0.17 & -- & 32 \\
\hline & $10 \ldots$ & $12: 40$ & .396 & -- & 0.036 & 9 & $29 \ldots$ & $21: 01$ & .142 & -- & 0.175 & 30 \\
\hline & $11 \ldots$ & $00: 40$ & .368 & -- & 0.037 & 8 & $29 \ldots$ & $23: 15$ & .218 & -- & 0.24 & 47 \\
\hline & $11 \ldots$ & $12: 40$ & .368 & -- & 0.051 & 9 & $30 \ldots$ & $01: 15$ & .193 & -- & 0.18 & 22 \\
\hline & $12 \ldots$ & $00: 40$ & .396 & -- & 0.039 & 8 & $30 \ldots$ & $03: 15$ & .156 & -- & 0.14 & 19 \\
\hline & $12 \ldots$ & $12: 15$ & .368 & 0.032 & -- & 2. & $30 \ldots$ & $05: 15$ & .127 & -- & 0.19 & 15 \\
\hline & $12 \ldots$ & $12: 40$ & .368 & -- & -- & 12 & $30 \ldots$ & $07: 15$ & .099 & -- & 0.18 & 13 \\
\hline & $12 \ldots$ & $12: 41$ & .368 & -- & 0.035 & 6 & $30 \ldots$ & $09: 15$ & .093 & 0.17 & -- & 11 \\
\hline & $13 \ldots$ & $16: 30$ & .396 & 0.034 & -- & 4 & $30 \ldots$ & $09: 16$ & .093 & -- & 0.15 & 15 \\
\hline & $13 \ldots$ & $20: 50$ & .481 & -- & -- & 17 & Jul 1982 & & & & & \\
\hline & $13 \ldots$ & $20: 51$ & .481 & -- & 0.044 & 8 & $28 \ldots$ & $14: 30$ & .006 & -- & 0.08 & -- \\
\hline & $14 \ldots$ & $18: 20$ & .510 & 0.04 & -- & 5 & $28 \ldots$ & $14: 31$ & .006 & 0.09 & -- & 2 \\
\hline & $14 \ldots$ & $22: 16$ & .510 & -- & 0.061 & 8 & $28 \ldots$ & $15: 30$ & .007 & -- & -- & 2 \\
\hline & $15 \ldots$ & $02: 15$ & .510 & -- & 0.047 & 5 & $28 \ldots$ & $16: 30$ & .008 & -- & 0.064 & -- \\
\hline & $15 \ldots$ & $06: 15$ & .481 & -- & 0.035 & 4 & $28 \ldots$ & $17: 30$ & .010 & -- & -- & 13 \\
\hline & $15 \ldots$ & $09: 45$ & .453 & -- & 0.036 & 9 & $28 \ldots$ & $18: 30$ & .011 & -- & 0.058 & - \\
\hline & $15 \ldots$ & $09: 46$ & .453 & 0.032 & -- & 3 & $28 \ldots$ & $19: 30$ & .013 & -- & -- & 6 \\
\hline & $16 \ldots$ & $15: 15$ & .510 & 0.055 & -- & 3 & $28 \ldots$ & $21: 30$ & .019 & -- & - & 10 \\
\hline & $17 \ldots$ & $01: 00$ & .566 & - & -- & 11 & $28 \ldots$ & $22: 15$ & .026 & 0.11 & -- & 12 \\
\hline & $17 \ldots$ & $19: 00$ & .708 & 0.039 & - & 3 & $28 \ldots$ & $22: 16$ & .026 & -- & 0.10 & 14 \\
\hline & $21 \ldots$ & $16: 15$ & .651 & -- & -- & 4 & $28 \ldots$ & $23: 15$ & .026 & -- & 0.09 & 26 \\
\hline & $26 \ldots$ & $14: 25$ & .263 & -- & -- & 2 & $29 \ldots$ & $00: 15$ & .048 & -- & 0.19 & 35 \\
\hline \multirow[t]{13}{*}{ May } & 1982 & & & & & & $29 \ldots$ & $01: 15$ & .051 & -- & 0.12 & 15 \\
\hline & $12 \ldots$ & $24: 00$ & .057 & -- & -- & 10 & $29 \ldots$ & $02: 15$ & .042 & -- & 0.09 & 8 \\
\hline & $20 \ldots$ & $16: 00$ & .051 & -- & 0.15 & 4 & $29 \ldots$ & $03: 15$ & .037 & -- & 0.09 & 8 \\
\hline & $20 \ldots$ & $16: 01$ & .051 & 0.14 & -- & 9 & $29 \ldots$ & $04: 15$ & .037 & -- & 0.08 & 6 \\
\hline & $20 \ldots$ & $16: 15$ & .051 & 0.15 & -- & 17 & $29 \ldots$ & $05: 15$ & .037 & -- & 0.08 & 9 \\
\hline & $20 \ldots$ & $18: 00$ & .062 & -- & 0.16 & 2 & $29 \ldots$ & $06: 15$ & .040 & -- & 0.08 & 6 \\
\hline & $20 \ldots$ & $20: 00$ & .068 & -- & 0.14 & 2 & Aug 1982 & & & & & \\
\hline & $20 \ldots$ & $22: 00$ & .068 & -- & 0.14 & 2 & $25 \ldots$ & $14: 00$ & .011 & 0.051 & -- & 2 \\
\hline & $20 \ldots$ & $24: 00$ & .079 & -- & 0.13 & 2 & $25 \ldots$ & $15: 00$ & .009 & -- & 0.056 & 4 \\
\hline & $21 \ldots$ & $02: 00$ & .076 & -- & 0.14 & 2 & $25 \ldots$ & $18: 00$ & .009 & -- & 0.051 & 6 \\
\hline & $21 \ldots$ & $04: 00$ & .068 & -- & 0.14 & 2 & $25 \ldots$ & $21: 00$ & .010 & -- & 0.063 & 8 \\
\hline & $21 \ldots$ & $06: 00$ & .065 & -- & 0.15 & 6 & $25 \ldots$ & $23: 00$ & .014 & -- & 0.071 & 9 \\
\hline & $21 \ldots$ & $08: 00$ & .062 & -- & 0.13 & 1 & & & & & & \\
\hline
\end{tabular}




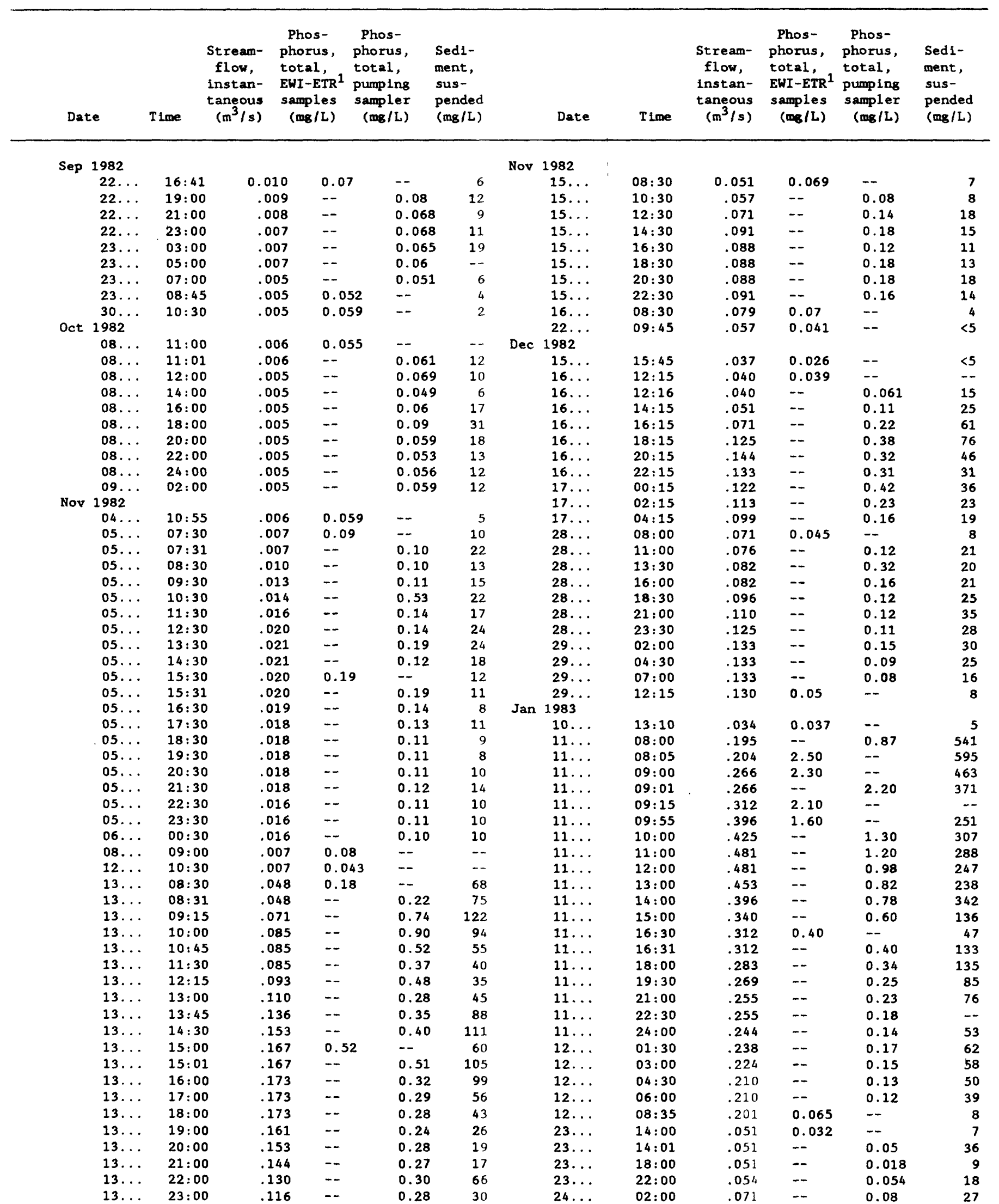


Table 6.-- Water-quality data from Johnson Brook at South Albion, Maine, October 1981 to September $1984--$ Continued

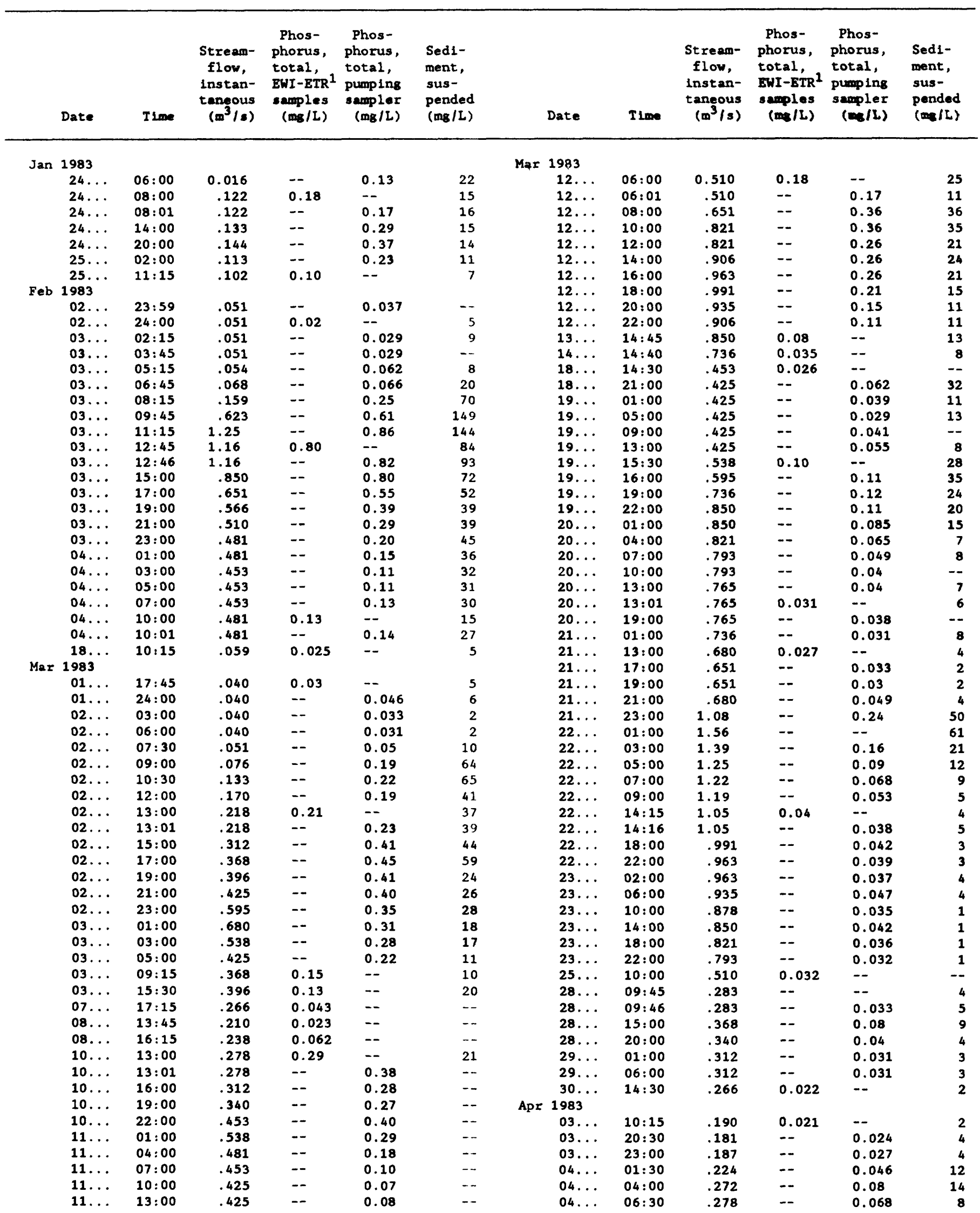




\begin{tabular}{|c|c|c|c|c|c|c|c|c|c|c|c|}
\hline Date & Time & $\begin{array}{l}\text { Stream- } \\
\text { flow, } \\
\text { Instan- } \\
\text { taneous } \\
\left(\mathrm{m}^{3} / \mathrm{s}\right)\end{array}$ & $\begin{array}{l}\text { Phos- } \\
\text { phorus, } \\
\text { total, } \\
\text { EWI-ETR } 1 \\
\text { samples } \\
\text { (ms/L) }\end{array}$ & $\begin{array}{l}\text { Phos- } \\
\text { phorus, } \\
\text { total, } \\
\text { pumplng } \\
\text { sampler } \\
\text { (mg/L) }\end{array}$ & $\begin{array}{l}\text { Sed1- } \\
\text { ment, } \\
\text { sus- } \\
\text { pended } \\
\text { (ms/L) }\end{array}$ & Date & Time & $\begin{array}{l}\text { Stream- } \\
\text { flow, } \\
\text { instan- } \\
\text { taneous } \\
\left(\mathrm{m}^{3} / \mathrm{s}\right)\end{array}$ & $\begin{array}{l}\text { Phos- } \\
\text { phorus, } \\
\text { total, } \\
\text { EWI-ETR } 1 \\
\text { samples } \\
\text { (ms/L) }\end{array}$ & $\begin{array}{l}\text { Phos- } \\
\text { phorus, } \\
\text { total, } \\
\text { pumping } \\
\text { sampler } \\
\text { (ms/L) }\end{array}$ & $\begin{array}{l}\text { Sed1- } \\
\text { mant, } \\
\text { sus - } \\
\text { pended } \\
(\text { mg/L) }\end{array}$ \\
\hline Apr 1983 & & & & & & Apr 1983 & & & & & \\
\hline $04 \ldots$ & $09: 00$ & 0.278 & -- & 0.052 & 7 & $25 \ldots$ & $11: 20$ & 1.64 & -- & 0.08 & 22 \\
\hline $04 \ldots$ & $11: 30$ & .278 & -- & 0.052 & 5 & $25 \ldots$ & $13: 00$ & 2.15 & -- & 0.10 & 25 \\
\hline $04 \ldots$ & $14: 00$ & .272 & -- & 0.05 & 8 & $25 \ldots$ & $14: 30$ & 2.12 & 0.22 & - & 22 \\
\hline $04 \ldots$ & $14: 23$ & .272 & 0.045 & -- & 4 & $25 \ldots$ & $14: 31$ & 2.12 & -- & 0.22 & 28 \\
\hline $07 \ldots$ & $15: 45$ & .204 & 0.025 & -- & 5 & $25 \ldots$ & $16: 00$ & 2.07 & -- & 0.09 & 18 \\
\hline $07 \ldots$ & $18: 00$ & .204 & -- & 0.03 & 20 & $25 \ldots$ & $17: 50$ & 1.98 & -- & 0.08 & 13 \\
\hline $07 \ldots$ & $21: 00$ & .204 & -- & 0.027 & 71 & $25 \ldots$ & $17: 51$ & 1.98 & 0.065 & -- & 10 \\
\hline $07 \ldots$ & $24: 00$ & .204 & -- & 0.03 & 76 & $25 \ldots$ & $20: 30$ & 1.93 & -- & 0.053 & 14 \\
\hline $08 \ldots$ & $03: 00$ & .204 & -- & 0.028 & 75 & $25 \ldots$ & $23: 00$ & 1.93 & -- & 0.05 & 15 \\
\hline $08 \ldots$ & $06: 00$ & .204 & -- & 0.027 & 70 & $26 \ldots$ & $01: 30$ & 1.95 & -- & 0.046 & 12 \\
\hline $08 \ldots$ & $09: 00$ & .204 & -- & 0.029 & 67 & $26 \ldots$ & $04: 00$ & 1.98 & -- & 0.24 & 11 \\
\hline $08 \ldots$ & $12: 00$ & .204 & -- & 0.028 & 67 & $26 \ldots$ & $06: 30$ & 1.95 & -- & 0.041 & 12 \\
\hline $08 \ldots$ & $15: 00$ & .204 & -- & 0.029 & 73 & $26 \ldots$ & $09: 00$ & 2.01 & -- & 0.04 & - \\
\hline $08 \ldots$ & $18: 00$ & .204 & -- & 0.029 & 67 & $26 \ldots$ & $11: 30$ & 2.01 & -- & 0.037 & 10 \\
\hline $10 \ldots$ & $19: 00$ & .173 & -- & 0.028 & 77 & $26 \ldots$ & $14: 00$ & 2.01 & -- & 0.041 & 10 \\
\hline $10 \ldots$ & $21: 00$ & .173 & -- & 0.02 & 78 & $26 \ldots$ & $16: 30$ & 2.01 & -- & 0.038 & 9 \\
\hline $10 \ldots$ & $23: 00$ & .173 & -- & 0.03 & 84 & $26 \ldots$ & $21: 30$ & 1.98 & -- & 0.027 & 10 \\
\hline $11 \ldots$ & $01: 00$ & .181 & -- & 0.037 & 91 & $27 \ldots$ & $01: 30$ & 1.93 & -- & 0.013 & 10 \\
\hline $11 \ldots$ & $03: 00$ & .312 & -- & 0.015 & 138 & $27 \ldots$ & $05: 30$ & 1.81 & -- & 0.032 & 10 \\
\hline $11 \ldots$ & $05: 00$ & .595 & -- & 0.20 & 134 & $27 \ldots$ & $09: 30$ & 1.70 & -- & 0.033 & 9 \\
\hline $11 \ldots$ & $07: 00$ & .595 & -- & 0.17 & 110 & $27 \ldots$ & $13: 30$ & 1.61 & -- & 0.037 & 8 \\
\hline $11 \ldots$ & $08: 45$ & .510 & 0.10 & -- & 53 & $27 \ldots$ & $17: 30$ & 1.56 & -- & 0.033 & 7 \\
\hline $11 \ldots$ & $08: 46$ & .510 & -- & 0.11 & 89 & $27 \ldots$ & $21: 30$ & 1.47 & -- & 0.034 & 8 \\
\hline $11 \ldots$ & $12: 00$ & .453 & -- & 0.065 & 83 & $28 \ldots$ & $01: 30$ & 1.36 & -- & 0.035 & 14 \\
\hline $11 \ldots$ & $15: 00$ & .453 & -- & 0.055 & -- & $28 \ldots$ & $05: 30$ & 1.27 & -- & 0.035 & 9 \\
\hline $11 \ldots$ & $18: 00$ & .425 & -- & 0.045 & 76 & May 1983 & & & & & \\
\hline $11 \ldots$ & $21: 00$ & .425 & -- & 0.045 & 82 & $02 \ldots$ & $08: 30$ & 0.425 & 0.052 & -- & 5 \\
\hline $11 \ldots$ & $24: 00$ & .425 & -- & 0.044 & 88 & $02 \ldots$ & $13: 30$ & .453 & 0.02 & -- & -- \\
\hline $12 \ldots$ & $03: 00$ & .425 & -- & 0.025 & 87 & $04 \ldots$ & $09: 00$ & .340 & 0.053 & -- & 5 \\
\hline $12 \ldots$ & $06: 00$ & .425 & -- & 0.025 & 82 & $09 \ldots$ & $14: 00$ & .283 & 0.055 & -- & 10 \\
\hline $12 \ldots$ & $09: 00$ & .425 & -- & 0.035 & 82 & $09 \ldots$ & $14: 01$ & .283 & -- & 0.072 & 22 \\
\hline $12 \ldots$ & $12: 00$ & .425 & 0.031 & -- & 59 & $09 \ldots$ & $23: 00$ & .278 & -- & 0.055 & 14 \\
\hline $16 \ldots$ & $18: 45$ & .238 & 0.027 & -- & 6 & $10 \ldots$ & $08: 00$ & .255 & -- & 0.054 & 12 \\
\hline $17 \ldots$ & $02: 00$ & .595 & -- & 0.28 & 193 & $10 \ldots$ & $14: 00$ & .244 & -- & 0.051 & 15 \\
\hline $17 \ldots$ & $04: 00$ & .991 & -- & 0.27 & 58 & $10 \ldots$ & $17: 00$ & .244 & -- & 0.052 & 16 \\
\hline $17 \ldots$ & $06: 00$ & .878 & -- & 0.15 & 28 & $10 \ldots$ & $23: 00$ & .238 & -- & 0.047 & 15 \\
\hline $17 \ldots$ & $08: 00$ & 1.10 & -- & 0.16 & 31 & $11 \ldots$ & $05: 00$ & .229 & -- & 0.049 & 15 \\
\hline $17 \ldots$ & $10: 00$ & 1.13 & -- & 0.15 & 28 & $11 \ldots$ & $11: 00$ & .224 & -- & 0.048 & 13 \\
\hline $17 \ldots$ & $12: 00$ & .991 & -- & 0.11 & 18 & $11 \ldots$ & $17: 00$ & .225 & -- & 0.048 & 17 \\
\hline $17 \ldots$ & $14: 00$ & 1.10 & -- & 0.11 & 16 & $12 \ldots$ & $14: 30$ & .198 & 0.045 & -- & 15 \\
\hline $17 \ldots$ & $16: 00$ & 1.27 & -- & 0.14 & 19 & $13 \ldots$ & $12: 45$ & .198 & 0.055 & -- & 17 \\
\hline $17 \ldots$ & $18: 00$ & 1.25 & -- & 0.11 & -- & $13 \ldots$ & $12: 46$ & .198 & -- & 0.09 & 81 \\
\hline $17 \ldots$ & $18: 30$ & 1.16 & 0.09 & - & 11 & $13 \ldots$ & $14: 15$ & .198 & -- & 0.067 & 23 \\
\hline $17 \ldots$ & $18: 45$ & 1.13 & 0.074 & -- & 11 & $13 \ldots$ & $15: 45$ & .198 & -- & 0.09 & 18 \\
\hline $17 \ldots$ & $18: 46$ & 1.13 & -- & 0.08 & 17 & $13 \ldots$ & $17: 15$ & .198 & -- & 0.04 & 19 \\
\hline $17 \ldots$ & $21: 00$ & 1.02 & -- & 0.078 & 14 & $13 \ldots$ & $20: 15$ & .198 & -- & 0.059 & 15 \\
\hline $17 \ldots$ & $23: 30$ & .991 & -- & 0.062 & 17 & $13 \ldots$ & $23: 15$ & .195 & -- & 0.053 & 14 \\
\hline $18 \ldots$ & $02: 00$ & .991 & -- & 0.046 & 11 & $15 \ldots$ & $10: 00$ & .170 & 0.055 & -- & 15 \\
\hline $18 \ldots$ & $04: 30$ & .991 & -- & 0.038 & 11 & $15 \ldots$ & $10: 01$ & .170 & -- & 0.078 & 51 \\
\hline $18 \ldots$ & $07: 00$ & 1.02 & -- & 0.046 & - & $15 \ldots$ & $12: 30$ & .178 & -- & 0.06 & 30 \\
\hline $18 \ldots$ & $09: 30$ & 1.02 & -- & 0.043 & 12 & $15 \ldots$ & $15: 00$ & .178 & -- & 0.064 & 19 \\
\hline $18 \ldots$ & $12: 00$ & 1.02 & -- & 0.038 & - & $15 \ldots$ & $17: 30$ & .173 & -- & 0.074 & 18 \\
\hline $18 \ldots$ & $14: 30$ & 1.02 & -- & 0.041 & -- & $15 \ldots$ & $22: 30$ & .173 & -- & 0.053 & 16 \\
\hline $18 \ldots$ & $14: 31$ & 1.02 & 0.04 & -- & 10 & $16 \ldots$ & $03: 30$ & .173 & -- & 0.059 & 14 \\
\hline $19 \ldots$ & $14: 00$ & .850 & 0.034 & -- & 6 & $16 \ldots$ & $17: 50$ & .161 & 0.049 & -- & - \\
\hline $24 \ldots$ & $14: 00$ & .312 & 0.03 & -- & 5 & $20 \ldots$ & $10: 30$ & .113 & 0.055 & -- & 14 \\
\hline $24 \ldots$ & $17: 00$ & .312 & -- & 0.057 & 12 & $20 \ldots$ & $13: 00$ & .122 & -- & 0.037 & 21 \\
\hline $24 \ldots$ & $19: 00$ & .538 & -- & 0.033 & 18 & $20 \ldots$ & $18: 00$ & .159 & -- & 0.034 & 27 \\
\hline $24 \ldots$ & $21: 00$ & 1.70 & -- & 0.20 & 66 & $20 \ldots$ & $23: 00$ & .153 & -- & 0.09 & 18 \\
\hline $24 \ldots$ & $23: 00$ & 3.40 & -- & 0.44 & 152 & $21 \ldots$ & $01: 30$ & .150 & -- & 0.078 & 15 \\
\hline $25 \ldots$ & $01: 00$ & 4.08 & -- & 0.48 & 234 & $22 \ldots$ & $21: 00$ & .116 & -- & 0.08 & 38 \\
\hline $25 \ldots$ & $03: 00$ & 3.68 & -- & 0.46 & 221 & $23 \ldots$ & $05: 00$ & .113 & -- & 0.05 & 13 \\
\hline $25 \ldots$ & $05: 00$ & 2.72 & -- & 0.30 & 104 & $23 \ldots$ & $07: 00$ & .125 & -- & 0.054 & 11 \\
\hline $25 \ldots$ & $07: 00$ & 2.15 & -- & 0.15 & 44 & $23 \ldots$ & $09: 00$ & .150 & -- & 0.08 & 17 \\
\hline $25 \ldots$ & $09: 00$ & 1.70 & -- & 0.10 & 35 & $23 \ldots$ & $11: 00$ & .153 & -- & 0.09 & -- \\
\hline
\end{tabular}


Table 6.-- Water-quality data from Johnson Brook at South Albion, Maine, October 1981 to September 1984--Continued

\begin{tabular}{|c|c|c|c|c|c|c|c|c|c|c|c|c|}
\hline & Date & Time & $\begin{array}{l}\text { Stream- } \\
\text { flow, } \\
\text { instan- } \\
\text { taneous } \\
\left(m^{3} / s\right)\end{array}$ & $\begin{array}{l}\text { Phos- } \\
\text { phorus, } \\
\text { total, } \\
\text { EWI-ETR } 1 \\
\text { samples } \\
(\mathrm{mg} / \mathrm{L})\end{array}$ & $\begin{array}{l}\text { Phos- } \\
\text { phorus, } \\
\text { total, } \\
\text { pumping } \\
\text { sampler } \\
\text { (mg/L) }\end{array}$ & $\begin{array}{l}\text { Sed 1- } \\
\text { ment, } \\
\text { sus- } \\
\text { pended } \\
\text { (mg/L) }\end{array}$ & Date & Time & $\begin{array}{l}\text { Stream- } \\
\text { flow, } \\
\text { instan- } \\
\text { taneous } \\
\left(\mathrm{m}^{3} / \mathrm{s}\right)\end{array}$ & $\begin{array}{l}\text { Phos- } \\
\text { phorus , } \\
\text { tota1, } \\
\text { EWI-BTR } 1 \\
\text { samples } \\
\text { (Es/L) }\end{array}$ & $\begin{array}{l}\text { Phos- } \\
\text { phorus, } \\
\text { total, } \\
\text { pumplng } \\
\text { sampler } \\
\text { (as/L) }\end{array}$ & $\begin{array}{l}\text { Sed 1- } \\
\text { mant, } \\
\text { sus - } \\
\text { pended } \\
\text { (mg/L) }\end{array}$ \\
\hline \multirow{27}{*}{ May } & 1983 & & & & & & Aug 1983 & & & & & \\
\hline & $23 \ldots$ & $13: 00$ & 0.150 & -- & 0.042 & 16 & $08 \ldots$ & $16: 00$ & 0.001 & 0.08 & -- & -- \\
\hline & $23 \ldots$ & $14: 30$ & .150 & 0.03 & -- & 12 & $09 \ldots$ & $01: 00$ & .001 & -- & 0.041 & 2 \\
\hline & $23 \ldots$ & $15: 30$ & .153 & - & 0.09 & 21 & $09 \ldots$ & $04: 00$ & .003 & -- & 0.05 & 5 \\
\hline & $23 \ldots$ & $18: 00$ & .150 & -- & 0.073 & 18 & $09 \ldots$ & $07: 00$ & .003 & -- & 0.042 & 2 \\
\hline & $23 \ldots$ & $23: 00$ & .144 & -- & 0.064 & 19 & $09 \ldots$ & $10: 00$ & .003 & -- & 0.039 & 0 \\
\hline & $24 \ldots$ & $11: 30$ & .144 & -- & 0.059 & 14 & $09 \ldots$ & $13: 00$ & .003 & -- & 0.075 & 3 \\
\hline & $24 \ldots$ & $14: 22$ & .144 & 0.032 & -- & 6 & $09 \ldots$ & $19: 00$ & .002 & -- & 0.047 & 0 \\
\hline & $26 \ldots$ & $14: 15$ & .122 & 0.037 & -- & 8 & $11 \ldots$ & $17: 00$ & .000 & -- & 0.049 & 2 \\
\hline & $27 \ldots$ & $21: 00$ & .195 & -- & 0.09 & -- & $11 \ldots$ & $21: 00$ & .000 & -- & 0.042 & 7 \\
\hline & $28 \ldots$ & $03: 00$ & .312 & -- & 0.15 & -- & $11 \ldots$ & $23: 00$ & .000 & -- & 0.039 & 5 \\
\hline & $28 \ldots$ & $09: 00$ & .255 & -- & 0.10 & -- & $12 \ldots$ & $01: 00$ & .001 & -- & 0.037 & 5 \\
\hline & $28 \ldots$ & $15: 00$ & .218 & -- & 0.058 & 24 & $12 \ldots$ & $03: 00$ & .005 & -- & -- & 7 \\
\hline & $28 \ldots$ & $21: 00$ & .212 & -- & 0.052 & -- & $12 \ldots$ & $05: 00$ & .009 & -- & 0.063 & 6 \\
\hline & $29 \ldots$ & $03: 00$ & .204 & -- & 0.05 & -- & $12 \ldots$ & $07: 00$ & .011 & -- & 0.063 & 6 \\
\hline & $29 \ldots$ & $09: 00$ & .204 & -- & 0.045 & $-\cdots$ & $12 \ldots$ & $09: 00$ & .012 & -- & 0.054 & 5 \\
\hline & $29 \ldots$ & $21: 00$ & .198 & -- & 0.043 & 12 & $12 \ldots$ & $12: 15$ & .019 & 0.09 & -- & 8 \\
\hline & $30 \ldots$ & $07: 00$ & .229 & 0.061 & -- & 6 & $12 \ldots$ & $18: 30$ & .023 & -- & 0.072 & 3 \\
\hline & $30 \ldots$ & $11: 00$ & .266 & -- & 0.10 & 25 & $13 \ldots$ & $05: 00$ & .016 & -- & 0.066 & 3 \\
\hline & $30 \ldots$ & $15: 00$ & .261 & -- & 0.09 & 17 & $13 \ldots$ & $15: 30$ & .010 & -- & 0.059 & 0 \\
\hline & $30 \ldots$ & $19: 00$ & .249 & -- & 0.07 & 15 & $31 \ldots$ & $13: 30$ & .037 & 0.09 & -- & - \\
\hline & $30 \ldots$ & $23: 00$ & .425 & -- & 0.19 & 58 & Oct 1983 & & & & & \\
\hline & $31 \ldots$ & $03: 00$ & .453 & -- & 0.18 & 30 & $13 \ldots$ & $13: 00$ & .031 & 0.51 & -- & 65 \\
\hline & $31 \ldots$ & $07: 00$ & .396 & -- & 0.11 & 26 & $13 \ldots$ & $17: 00$ & .020 & -- & 0.22 & 11 \\
\hline & $31 \ldots$ & $11: 00$ & .368 & -- & 0.067 & 13 & $13 \ldots$ & $21: 00$ & .015 & -- & 0.17 & 6 \\
\hline & $31 \ldots$ & $15: 00$ & .368 & -- & 0.07 & 15 & $14 \ldots$ & $09: 00$ & .010 & -- & 0.12 & 4 \\
\hline & $31 \ldots$ & $15: 30$ & .368 & 0.044 & -- & -- & Nov 1983 & & & & & \\
\hline \multirow[t]{38}{*}{ Jun } & 1983 & & & & & & $04 \ldots$ & $15: 00$ & .002 & -- & 0.11 & - \\
\hline & $03 \ldots$ & $15: 00$ & .266 & 0.062 & -- & -- & $04 \ldots$ & $15: 01$ & .002 & 0.12 & - & - \\
\hline & $04 \ldots$ & $07: 00$ & .238 & -- & 0.037 & 13 & $04 \ldots$ & $24: 00$ & .002 & -- & 0.072 & - \\
\hline & $04 \ldots$ & $10: 00$ & .272 & -- & 0.045 & 10 & $05 \ldots$ & $11: 30$ & .009 & 0.10 & $\ldots$ & -- \\
\hline & $04 \ldots$ & $13: 00$ & .266 & -- & 0.047 & 13 & $05 \ldots$ & $11: 31$ & .009 & -- & 0.11 & 6 \\
\hline & $04 \ldots$ & $16: 00$ & .283 & - & 0.057 & - & $05 \ldots$ & $14: 30$ & .057 & -- & 0.22 & 19 \\
\hline & $04 \ldots$ & $19: 00$ & .283 & - & 0.049 & 12 & $05 \ldots$ & $17: 30$ & .062 & -- & 0.51 & 18 \\
\hline & $04 \ldots$ & $21: 00$ & .278 & -- & 0.042 & 12 & $05 \ldots$ & $20: 30$ & .059 & -- & 0.38 & 11 \\
\hline & $04 \ldots$ & $24: 00$ & .266 & -- & 0.057 & - & $05 \ldots$ & $23: 30$ & .059 & -- & 0.40 & 9 \\
\hline & $05 \ldots$ & $03: 00$ & .255 & - & 0.046 & -- & $06 \ldots$ & $02: 30$ & .048 & -- & 0.48 & - \\
\hline & $05 \ldots$ & $06: 00$ & .255 & -- & 0.036 & 9 & $06 \ldots$ & $05: 30$ & .040 & -- & 0.54 & 11 \\
\hline & $24 \ldots$ & $15: 30$ & .014 & 0.066 & $\ldots$ & -- & $06 \ldots$ & $08: 30$ & .034 & - & 0.62 & - \\
\hline & 1983 & & & & & & $06 \ldots$ & $11: 30$ & .031 & -- & 0.66 & 15 \\
\hline & $01 \ldots$ & $14: 45$ & .008 & 0.062 & -- & -- & $07 \ldots$ & $11: 00$ & .015 & 0.41 & -- & - \\
\hline & $06 \ldots$ & $13: 15$ & .018 & 0.075 & -- & -- & $10 \ldots$ & $14: 15$ & .011 & 0.12 & - & $<5$ \\
\hline & $07 \ldots$ & $19: 00$ & .013 & -- & 0.061 & -- & $10 \ldots$ & $20: 00$ & .010 & -- & 0.22 & $<5$ \\
\hline & $08 \ldots$ & $01: 00$ & .013 & -- & 0.06 & -- & $10 \ldots$ & $23: 00$ & .010 & -- & 0.12 & $<5$ \\
\hline & $08 \ldots$ & $07: 00$ & .012 & -- & 0.063 & - & $11 \ldots$ & $02: 00$ & .010 & - & 0.11 & $<5$ \\
\hline & $15 \ldots$ & $15: 15$ & .010 & 0.062 & -- & -- & $11 \ldots$ & $08: 00$ & .059 & -- & 0.22 & $<5$ \\
\hline & $15 \ldots$ & $22: 00$ & .010 & -- & 0.049 & -- & $11 \ldots$ & $11: 00$ & .062 & -- & 0.25 & $<5$ \\
\hline & $16 \ldots$ & $04: 00$ & .010 & -- & 0.054 & -- & $11 \ldots$ & $14: 00$ & .062 & -- & 0.26 & $<5$ \\
\hline & $16 \ldots$ & $10: 00$ & .009 & -- & 0.035 & - & $11 \ldots$ & $20: 00$ & .054 & -- & 0.28 & $<5$ \\
\hline & $21 \ldots$ & $05: 00$ & .005 & -- & 0.057 & -- & $15 \ldots$ & $15: 00$ & .042 & 0.041 & - & - \\
\hline & $21 \ldots$ & $07: 00$ & .005 & -- & 0.059 & -- & $15 \ldots$ & $24: 00$ & .042 & -- & 0.039 & 1 \\
\hline & $21 \ldots$ & $09: 00$ & .005 & -- & 0.046 & -- & $16 \ldots$ & $06: 00$ & .042 & -- & 0.037 & 1 \\
\hline & $21 \ldots$ & $11: 00$ & .005 & -- & 0.054 & -- & $16 \ldots$ & $12: 00$ & .057 & -- & 0.04 & 2 \\
\hline & $21 \ldots$ & $13: 00$ & .005 & -- & 0.056 & -- & $16 \ldots$ & $15: 00$ & .161 & 0.17 & - & 23 \\
\hline & $21 \ldots$ & $15: 00$ & .005 & -- & 0.043 & -- & $16 \ldots$ & $15: 01$ & .161 & -- & 0.18 & 20 \\
\hline & $21 \ldots$ & $15: 30$ & .005 & 0.058 & - & -- & $16 \ldots$ & $18: 00$ & .283 & -- & 0.37 & 16 \\
\hline & $21 \ldots$ & $17: 00$ & .005 & -- & 0.06 & -- & $16 \ldots$ & $21: 00$ & .312 & -- & 0.38 & 11 \\
\hline & $21 \ldots$ & $19: 00$ & .006 & -- & 0.056 & $\cdots$ & $16 \ldots$ & $24: 00$ & .283 & -- & 0.35 & 6 \\
\hline & $21 \ldots$ & $21: 00$ & .006 & -- & 0.056 & -- & $17 \ldots$ & $03: 00$ & .249 & -- & 0.30 & 3 \\
\hline & $24 \ldots$ & $10: 30$ & .007 & 0.052 & -- & -- & $17 \ldots$ & $06: 00$ & .201 & -- & 0.22 & 3 \\
\hline & $24 \ldots$ & $18: 00$ & .007 & - & 0.029 & -- & $17 \ldots$ & $11: 45$ & .161 & 0.16 & - & 2 \\
\hline & $24 \ldots$ & $24: 00$ & .007 & -- & 0.048 & -- & $17 \ldots$ & $11: 46$ & .161 & -- & 0.17 & 2 \\
\hline & $25 \ldots$ & $06: 00$ & .007 & - & 0.029 & -- & $21 \ldots$ & $08: 15$ & .130 & 0.033 & - & 5 \\
\hline & $25 \ldots$ & $13: 40$ & .007 & 0.051 & -- & -- & $21 \ldots$ & $10: 30$ & .136 & - & 0.045 & 4 \\
\hline & $29 \ldots$ & $14: 40$ & .003 & 0.065 & -- & -- & $21 \ldots$ & $13: 00$ & .170 & -- & 0.079 & 4 \\
\hline
\end{tabular}




\begin{tabular}{|c|c|c|c|c|c|c|c|c|c|c|c|c|}
\hline & Date & Time & $\begin{array}{l}\text { Stream- } \\
\text { flow, } \\
\text { instan- } \\
\text { tangous } \\
\left(\mathrm{m}^{3} / \mathrm{s}\right)\end{array}$ & $\begin{array}{l}\text { Phos- } \\
\text { phorus, } \\
\text { totel, } \\
\text { EWI-EIR } 1 \\
\text { samples } \\
\text { (mg/L) }\end{array}$ & $\begin{array}{l}\text { Phos- } \\
\text { phorus, } \\
\text { total, } \\
\text { pumpins } \\
\text { sampler } \\
\text { (mg/L) }\end{array}$ & $\begin{array}{l}\text { Sedi- } \\
\text { ment, } \\
\text { sus- } \\
\text { pended } \\
\text { (mg/L) }\end{array}$ & Date & Time & $\begin{array}{l}\text { Stream- } \\
\text { flow, } \\
\text { Instan- } \\
\text { taneous } \\
\left(\mathrm{m}^{3} / \mathrm{s}\right)\end{array}$ & $\begin{array}{l}\text { Phos- } \\
\text { phorus, } \\
\text { total, } \\
\text { ENI-BIR } 1 \\
\text { samples } \\
\text { (ms/L) }\end{array}$ & $\begin{array}{l}\text { Phos - } \\
\text { phorus, } \\
\text { total, } \\
\text { pump 1ng } \\
\text { sampler } \\
\text { (mg/L) }\end{array}$ & $\begin{array}{l}\text { Sedi- } \\
\text { ment, } \\
\text { sus- } \\
\text { pended } \\
\text { (mg/L) }\end{array}$ \\
\hline \multirow[t]{26}{*}{ Nov } & 1983 & & & & & & Feb 1984 & & & & & \\
\hline & $21 \ldots$ & $15: 30$ & 0.510 & -- & 0.58 & 32 & $04 \ldots$ & $03: 00$ & 0.102 & -- & 0.30 & 24 \\
\hline & $21 \ldots$ & $18: 00$ & .538 & -- & 0.61 & 23 & $04 \ldots$ & $07: 00$ & .312 & -- & 0.40 & 19 \\
\hline & $21 \ldots$ & $20: 30$ & .453 & -- & 0.34 & 13 & $04 \ldots$ & $11: 00$ & .510 & -- & 0.26 & 14 \\
\hline & $21 \ldots$ & $23: 00$ & .340 & -- & 0.22 & 10 & $04 \ldots$ & $15: 00$ & .425 & -- & 0.35 & 13 \\
\hline & $22 \ldots$ & $01: 30$ & .312 & -- & 0.16 & 8 & $04 \ldots$ & $19: 00$ & .340 & -- & 0.26 & 9 \\
\hline & $22 \ldots$ & $04: 00$ & .312 & -- & 0.13 & 9 & $04 \ldots$ & $23: 00$ & .283 & -- & 0.21 & 8 \\
\hline & $23 \ldots$ & $12: 15$ & .283 & 0.038 & -- & -- & $05 \ldots$ & $03: 00$ & .312 & -- & 0.13 & 8 \\
\hline & $24 \ldots$ & $23: 00$ & .283 & -- & 0.036 & 5 & $05 \ldots$ & $07: 00$ & .203 & -- & 0.088 & 6 \\
\hline & $25 \ldots$ & $02: 00$ & .312 & -- & 0.11 & 9 & $05 \ldots$ & $11: 00$ & .261 & - & 0.055 & 4 \\
\hline & $25 \ldots$ & $05: 00$ & .708 & -- & 0.33 & 22 & $06 \ldots$ & $11: 45$ & .193 & 0.035 & -- & -- \\
\hline & $25 \ldots$ & $11: 30$ & 1.27 & 0.34 & -- & 14 & $10 \ldots$ & $16: 00$ & .136 & 0.022 & -- & -- \\
\hline & $25 \ldots$ & $11: 31$ & 1.27 & - & 0.36 & 19 & $12 \ldots$ & $12: 00$ & .136 & -- & 0.025 & 5 \\
\hline & $25 \ldots$ & $14: 30$ & 1.93 & -- & 0.52 & 32 & $12 \ldots$ & $18: 00$ & .283 & -- & 0.39 & 15 \\
\hline & $25 \ldots$ & $17: 30$ & 1.73 & -- & 0.40 & 17 & $12 \ldots$ & $24: 00$ & .232 & -- & 0.12 & 9 \\
\hline & $25 \ldots$ & $20: 30$ & 1.42 & -- & 0.28 & 10 & $13 \ldots$ & $06: 00$ & .193 & -- & 0.052 & 5 \\
\hline & $25 \ldots$ & $23: 30$ & 1.22 & -- & 0.14 & 7 & $14 \ldots$ & $12: 00$ & .176 & -- & 0.033 & 5 \\
\hline & $26 \ldots$ & $02: 30$ & 1.19 & -- & -- & 5 & $14 \ldots$ & $12: 01$ & .176 & 0.37 & -- & -- \\
\hline & $26 \ldots$ & $05: 30$ & 1.16 & -- & 0.08 & 5 & $15 \ldots$ & $04: 00$ & .232 & -- & 0.14 & 5 \\
\hline & $26 \ldots$ & $08: 30$ & 1.19 & -- & 0.07 & 5 & $15 \ldots$ & $12: 00$ & .453 & -- & 0.39 & 18 \\
\hline & $26 \ldots$ & $11: 30$ & 1.22 & -- & 0.056 & 7 & $15 \ldots$ & $14: 45$ & 1.33 & -- & 0.70 & 76 \\
\hline & $28 \ldots$ & $13: 15$ & .850 & 0.026 & -- & - & $15 \ldots$ & $14: 46$ & 1.33 & 0.63 & -- & 83 \\
\hline & $29 \ldots$ & $06: 00$ & .736 & -- & 0.024 & 2 & $15 \ldots$ & $18: 00$ & .821 & -- & 0.18 & 20 \\
\hline & $29 \ldots$ & $12: 00$ & .736 & -- & 0.049 & 2 & $15 \ldots$ & $21: 00$ & .850 & -- & 0.24 & 10 \\
\hline & $29 \ldots$ & $18: 00$ & .736 & -- & 0.067 & 2 & $15 \ldots$ & $24: 00$ & .793 & -- & 0.16 & 8 \\
\hline & $29 \ldots$ & $24: 00$ & .708 & -- & 0.05 & 2 & $16 \ldots$ & $03: 00$ & .765 & -- & 0.12 & 6 \\
\hline \multirow[t]{40}{*}{ Dec } & 1983 & & & & & & $16 \ldots$ & $10: 30$ & .736 & 0.058 & -- & 5 \\
\hline & $02 \ldots$ & $14: 00$ & .368 & 0.022 & - & -- & $17 \ldots$ & $14: 30$ & .651 & 0.028 & -- & 11 \\
\hline & $06 \ldots$ & $11: 15$ & .224 & 0.022 & -- & -- & $18 \ldots$ & $06: 00$ & .566 & -- & 0.023 & 2 \\
\hline & $06 \ldots$ & $19: 00$ & .224 & -- & 0.022 & 2 & $19 \ldots$ & $14: 00$ & .453 & -- & 0.024 & 4 \\
\hline & $06 \ldots$ & $23: 00$ & .283 & -- & 0.04 & 5 & $20 \ldots$ & $06: 00$ & .425 & -- & 0.033 & 1 \\
\hline & $07 \ldots$ & $01: 00$ & .935 & -- & 0.35 & 37 & $20 \ldots$ & $14: 00$ & .425 & -- & 0.063 & 1 \\
\hline & $07 \ldots$ & $03: 00$ & 1.16 & -- & 0.36 & 20 & $20 \ldots$ & $22: 00$ & .425 & -- & 0.031 & 3 \\
\hline & $07 \ldots$ & $05: 00$ & 1.13 & -- & 0.24 & 12 & $23 \ldots$ & $13: 45$ & .312 & 0.015 & -- & - \\
\hline & $07 \ldots$ & $07: 00$ & .963 & -- & 0.19 & 7 & $24 \ldots$ & $10: 00$ & .283 & 0.015 & -- & -- \\
\hline & $07 \ldots$ & $11: 00$ & .680 & 0.12 & -- & 5 & $24 \ldots$ & $12: 00$ & .283 & -- & 0.026 & 5 \\
\hline & $07 \ldots$ & $11: 01$ & .680 & - & 0.13 & 6 & $24 \ldots$ & $15: 00$ & .312 & 0.038 & -- & 5 \\
\hline & $07 \ldots$ & $15: 00$ & .595 & -- & 0.081 & 3 & $24 \ldots$ & $17: 00$ & .340 & -- & 0.11 & 15 \\
\hline & $07 \ldots$ & $21: 00$ & .595 & -- & 0.047 & 2 & $24 \ldots$ & $22: 00$ & .510 & -- & 0.13 & 11 \\
\hline & $08 \ldots$ & $03: 00$ & .595 & -- & 0.032 & 2 & $25 \ldots$ & $03: 00$ & .425 & -- & 0.057 & 6 \\
\hline & $13 \ldots$ & $11: 40$ & 1.08 & 0.14 & -- & 7 & $25 \ldots$ & $08: 00$ & .340 & -- & 0.032 & 1 \\
\hline & $13 \ldots$ & $11: 41$ & 1.08 & -- & 0.14 & 9 & $25 \ldots$ & $13: 00$ & .368 & -- & 0.019 & 0 \\
\hline & $13 \ldots$ & $13: 30$ & 1.47 & -- & 0.21 & 14 & $25 \ldots$ & $18: 00$ & .368 & -- & 0.02 & 0 \\
\hline & $13 \ldots$ & $15: 30$ & 1.47 & - & 0.24 & 12 & $25 \ldots$ & $23: 00$ & .453 & -- & 0.037 & 6 \\
\hline & $13 \ldots$ & $17: 30$ & 1.42 & -- & 0.23 & 17 & $26 \ldots$ & $04: 00$ & .680 & -- & 0.23 & 9 \\
\hline & $13 \ldots$ & $19: 30$ & 1.42 & -- & 0.20 & 10 & $\operatorname{Mar} 1984$ & & & & & \\
\hline & $13 \ldots$ & $21: 30$ & 1.36 & -- & 0.26 & 12 & $01 \ldots$ & $15: 15$ & .425 & 0.01 & -- & -- \\
\hline & $13 \ldots$ & $23: 30$ & 1.81 & -- & 0.28 & 17 & $07 \ldots$ & $16: 30$ & .142 & 0.02 & -- & $=-$ \\
\hline & $14 \ldots$ & $01: 30$ & 1.64 & -- & 0.20 & 11 & $19 \ldots$ & $10: 00$ & .232 & -- & 0.039 & 5 \\
\hline & $14 \ldots$ & $03: 30$ & 1.56 & -- & 0.15 & 9 & $19 \ldots$ & $13: 00$ & .275 & -- & 0.04 & 6 \\
\hline & $14 \ldots$ & $09: 00$ & 1.64 & 0.13 & -- & 4 & $19 \ldots$ & $16: 00$ & .312 & -- & 0.054 & 5 \\
\hline & $14 \ldots$ & $09: 01$ & 1.64 & -- & 0.13 & 6 & $19 \ldots$ & $19: 00$ & .368 & -- & 0.063 & 6 \\
\hline & $14 \ldots$ & $15: 00$ & 1.50 & -- & 0.061 & 6 & $19 \ldots$ & $22: 00$ & .453 & -- & 0.068 & 5 \\
\hline & $15 \ldots$ & $03: 00$ & 1.56 & -- & 0.036 & 5 & $20 \ldots$ & $01: 00$ & .453 & - & 0.07 & 5 \\
\hline & $15 \ldots$ & $15: 00$ & 1.53 & -- & 0.036 & 2 & $20 \ldots$ & $04: 00$ & .453 & -- & 0.074 & 4 \\
\hline & $16 \ldots$ & $09: 00$ & 1.30 & -- & 0.028 & 1 & $20 \ldots$ & $10: 00$ & .453 & -- & 0.065 & 5 \\
\hline & $28 \ldots$ & $14: 00$ & .088 & 0.018 & -- & -- & $20 \ldots$ & $16: 45$ & .453 & -- & - & 15 \\
\hline & $28 \ldots$ & $20: 00$ & .088 & -- & 0.022 & 2 & $20 \ldots$ & $17: 00$ & .453 & -- & 0.09 & 10 \\
\hline & $28 \ldots$ & $22: 00$ & .116 & -- & 0.04 & 3 & $21 \ldots$ & $01: 00$ & .425 & -- & 0.085 & 5 \\
\hline & $28 \ldots$ & $24: 00$ & .736 & -- & 0.20 & 25 & $21 \ldots$ & $09: 00$ & .368 & -- & 0.055 & 4 \\
\hline & $29 \ldots$ & $02: 00$ & .708 & -- & 0.32 & 11 & $21 \ldots$ & $17: 00$ & .425 & -- & 0.05 & 5 \\
\hline & $29 \ldots$ & $04: 00$ & .453 & -- & 0.36 & 9 & $22 \ldots$ & $01: 00$ & .425 & -- & 0.048 & 5 \\
\hline & $29 \ldots$ & $06: 00$ & .368 & -- & 0.22 & 6 & $22 \ldots$ & $09: 00$ & .651 & -- & 0.089 & 10 \\
\hline & $29 \ldots$ & $08: 00$ & .312 & -- & 0.15 & 5 & $22 \ldots$ & $17: 00$ & .878 & -- & 0.093 & 10 \\
\hline & $29 \ldots$ & $10: 00$ & .283 & 0.10 & -- & 4 & 23. & $01: 00$ & .878 & -- & 0.044 & 6 \\
\hline & $29 \ldots$ & $10: 01$ & .283 & -- & 0.11 & 4 & & & & & & \\
\hline
\end{tabular}




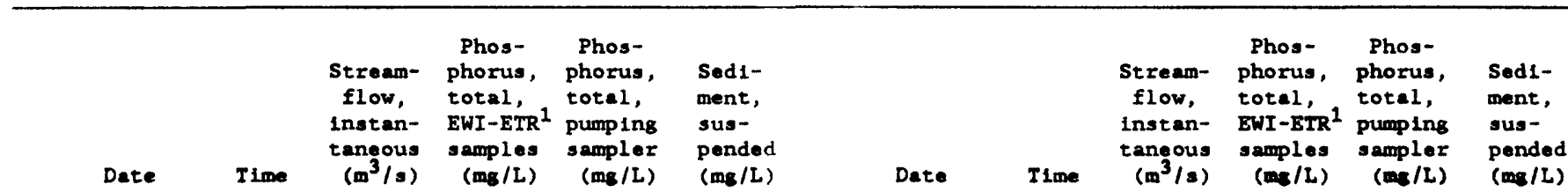

Mar 1984

$\begin{array}{rr}23 & 09: 00 \\ 30 & 12: 00\end{array}$

Apr 1984

03... 07:00

$04 \ldots \quad 17: 15$

$04 \ldots \quad 17: 16$

05... $02: 00$

05... 04:00

$05 \ldots \quad 06: 00$

05... 08:00

$05 \ldots \quad 10: 00$

05... 12:00

$05 \ldots 14: 00$

$05 \ldots \quad 15: 45$

05... 15:50

$05 \ldots \quad 17: 30$

05... 19:00

05... 20:30

$05 \ldots 22: 00$

$05 \ldots 23: 30$

$06 \ldots 01: 00$

06... 02:30

$06 \ldots \quad 04: 00$

06... 05:30

06... 12:00

$06 \ldots \quad 12: 01$

06... 20:00

$07 \ldots \quad 04: 00$

$07 \ldots 12: 00$

$07 \ldots \quad 20: 00$

08... 04:00

08... 12:00

$08 \ldots \quad 20: 00$

09... 04:00

$14 \ldots 14: 00$

$14 \ldots 18: 00$

$15 \ldots 22: 00$

$16 \ldots 02: 00$

$16 \ldots 08: 20$

16... 11:00

$16 \ldots 15: 00$

16... 21:00

$17 \ldots$ 01:00

$17 \ldots \quad 03: 00$

$17 \ldots 08: 35$

17... 09:00

18... 03:00

18... 21:00

19... 09:00

$20 \ldots 15: 30$

23... 20:00

24... 08:00

$24 \ldots 24: 00$

25... 12:00

$27 \ldots 10: 30$

May 1984

$03 \ldots 02: 00$

$03 \ldots 08: 00$

03... 10:00

$03 \ldots 12: 00$

03... 14:00

$03 \ldots 16: 00$

03... 18:00

$08 \ldots \quad 16: 15$

$08 \ldots 21: 00$

$0.850 \quad-\quad 0032 \quad 0.032 \quad$ May 1984

$\begin{array}{llll}0.850 & - & 0.032 & 2 \\ 312 & 0.02 & - & \end{array}$

.453

.566

.566

.510

.510

.510

.510

.595

.623

.623

.623

.850

1.16

1.76

2. 10

2.27

2. 27

2.10

1.56

1.56

1.61

1. 61

1.61

1.61
1.50

1.36

1.25

1.13

.453
.453

.368

.425

.425

.425

.510

.510
.510

.453

.453

.453

.425
.425

.368

.283

.283

.312

.312

.283

.156

.156

.156

.147

.147
.136

.136

.156

.161

$\begin{array}{llr}-- & 0.066 & 3 \\ 0.065 & -- & 12 \\ -- & 0.081 & 11\end{array}$

$\begin{array}{lll}-- & 0.081 & 11 \\ -- & 0.035 & -- \\ -- & 0.03 & --\end{array}$

$\begin{array}{lll}-- & 0.03 & -- \\ -- & 0.029 & --\end{array}$

-- $0.059 \quad 0$.

$\begin{array}{lll}-- & 0.032 & - \\ -- & 0.034 & -\end{array}$

- $\quad 0.078$

$-0.09$

0.055

-. 0.05

$-0.088$

0.33

$\begin{array}{ll}-- & 0.47 \\ -- & 0.36\end{array}$

-- 0.27

0.20

$--\quad 0.15$

0.067

$\begin{array}{ll}0.059 & -- \\ - & 0.051\end{array}$

-- 0.041

-- $\quad 0.039$

-
$-\quad 0.034$
$-\quad 0.029$

0.03

- $\quad 0.026$

0.025

0.028

0.031

0.023

0.047

- $\quad 0.035$

- $\quad 0.029$

_. $\quad 0.049$

- 0.031

0.03 --

-- 0.034

0.026
-

- $\quad 0.031$

0.039

- $\quad 0.027$

0.041

0.025

0.034

-- 0.044

-- 0.043

0.051

-- $\quad 0.076$

0.081

$\begin{array}{ll}-- & 0.07 \\ -- & 0.057\end{array}$

0.032

0.04
- 0.18
May 1984

08... 23:00

$\begin{array}{ll}09 \ldots & 01: 00 \\ 09 \ldots & 03: 00\end{array}$

$\begin{array}{ll}09 \ldots & 03: 00 \\ 09 \ldots & 05: 00\end{array}$

09... 07:00

09... 09:00

$09 \ldots \quad 11: 00$

$09 . . .13: 00$

$11 \ldots 16: 30$

$11 \ldots 24: 00$

$12 \ldots \quad 05: 00$

12... 10:00

12... 15:00

12... 20:00

13... 01:00

$13 \ldots 00: 00$

13... 11:00

13... 16:00

25... 15:00

26... 07:00

27... 07:00

27... 13:00

$27 \ldots$ 19:00

28... $01: 00$

28... $07: 00$

29... $09: 40$

29... 12:45

29... 15:00

29... 18:00

29... 21:00

29... 24:00

30... 03:00

30... 06:00

$30 \ldots 15: 00$

30... 18:00

$31 \ldots 06: 00$

31... 09:00

31... 12:00

31... 13:45

31... 14:00

$31 \ldots 16: 00$

$31 \ldots \quad 18: 00$

$31 \ldots \quad 20: 00$

31... 22:00

Jun 1984

$01 \ldots 02: 00$

$01.02: 00$

$01 \ldots$ 06:00

01... 08:00

$01 \ldots 16: 30$

$02 \ldots 13: 00$

$02 \ldots \quad 13: 15$

02... 14:00

$02 \ldots 16: 00$

$02 \ldots \quad 18: 00$

02... 20:00

02... 22:00

02... 24:00

$03 \ldots \quad 02: 00$

03... 04:00

03... 06:00

$04 \ldots \quad 12: 35$

$08 \ldots 16: 15$

$08 \ldots 1$ 17:00

0.161

170 - $\quad 0.046$

$.170 \quad--\quad 0.046$

$.170 \quad \ldots \quad 0.041$

$\begin{array}{llll}.170 & -- & 0.042 & -- \\ .170 & -- & 0.038 & --\end{array}$

$.170 \quad--\quad 0.037 \quad 2$

.142

.130

.130

.201

.283

.453

.368

.340
.340

.051

.042

.054

.042

.037

.034
.031

.074

.102

.184

.368

.765

.850

.736
.595

.680

.680

.736
1.93

1.47

1.42

1. 78

1.04

1.98

1. 81

2. 15

2.44

2.29

2. 01

1.84

1.78

1.95

2. 78

2. 92

3.12

2. 78

2.44

2.27

2.15

2. 10

2. 04

2.01

1.98 
Table 6.-- Water-quality data from Johnson Brook at South Albion, Maine, October 1981 to September $1984--$ Cont1nued

\begin{tabular}{|c|c|c|c|c|c|c|c|c|c|c|c|c|}
\hline & Date & Time & $\begin{array}{l}\text { Stream- } \\
\text { flow, } \\
\text { instan- } \\
\text { taneous } \\
\left(\mathrm{m}^{3} / \mathrm{s}\right)\end{array}$ & $\begin{array}{l}\text { Phos- } \\
\text { phorus, } \\
\text { total, } \\
\text { EWI-EIR } 1 \\
\text { samples } \\
\text { (mg/L) }\end{array}$ & $\begin{array}{l}\text { Phos- } \\
\text { phorus, } \\
\text { total, } \\
\text { pumping } \\
\text { sampler } \\
\text { (mg/L) }\end{array}$ & $\begin{array}{l}\text { Sedi- } \\
\text { ment, } \\
\text { sus- } \\
\text { pended } \\
(\mathrm{mg} / L)\end{array}$ & Date & T Ine & $\begin{array}{l}\text { Stream- } \\
\text { flow, } \\
\text { instan- } \\
\text { taneous } \\
\left(m^{3} / \mathrm{s}\right)\end{array}$ & $\begin{array}{l}\text { Phos- } \\
\text { phorus, } \\
\text { total, } \\
\text { EWI-EIR } 1 \\
\text { samples } \\
\text { (mo/L) }\end{array}$ & $\begin{array}{l}\text { Phos- } \\
\text { phorus, } \\
\text { total, } \\
\text { pumping } \\
\text { sampler } \\
\text { (mg/L) }\end{array}$ & $\begin{array}{l}\text { Sed1- } \\
\text { ment, } \\
\text { sus- } \\
\text { pended } \\
\text { (mg/L) }\end{array}$ \\
\hline \multirow[t]{25}{*}{ Jun } & 1984 & & & & & & Jul 1984 & & & & & \\
\hline & $08 \ldots$ & $18: 30$ & 0.623 & -- & 0.036 & 1 & $07 \ldots$ & $12: 00$ & 0.051 & -- & 0.058 & -- \\
\hline & $08 \ldots$ & $20: 00$ & .623 & -- & 0.035 & 3 & $07 \ldots$ & $15: 00$ & .054 & -- & 0.058 & 6 \\
\hline & $08 \ldots$ & $21: 30$ & .623 & -- & 0.034 & 2 & $07 \ldots$ & $18: 00$ & .065 & -- & 0.061 & -- \\
\hline & $08 \ldots$ & $23: 00$ & .623 & -- & 0.035 & 2 & $07 \ldots$ & $21: 00$ & .076 & -- & 0.066 & 7 \\
\hline & $09 \ldots$ & $00: 30$ & .595 & -- & 0.035 & 3 & $07 \ldots$ & $24: 00$ & .088 & -- & 0.077 & -- \\
\hline & $09 \ldots$ & $02: 00$ & .595 & -- & 0.087 & 15 & $08 \ldots$ & $03: 00$ & .088 & -- & 0.065 & 6 \\
\hline & $09 \ldots$ & $03: 30$ & .595 & -- & 0.13 & 11 & $08 \ldots$ & $06: 00$ & .085 & -- & 0.079 & -- \\
\hline & $09 \ldots$ & $05: 00$ & .566 & -- & 0.083 & 7 & $08 \ldots$ & $09: 00$ & .079 & -- & 0.08 & 6 \\
\hline & $20 \ldots$ & $17: 30$ & .040 & 0.04 & -- & -- & $10 \ldots$ & $10: 50$ & .054 & 0.062 & -- & -- \\
\hline & $25 \ldots$ & $09: 45$ & .054 & 0.054 & -- & 11 & $11 \ldots$ & $16: 25$ & .045 & 0.05 & -- & -- \\
\hline & $25 \ldots$ & $13: 00$ & .076 & -- & 0.056 & 12 & $11 \ldots$ & $19: 00$ & .045 & -- & 0.054 & 4 \\
\hline & $25 \ldots$ & $16: 00$ & .079 & -- & 0.054 & 3 & $11 \ldots$ & $21: 00$ & .045 & -- & 0.054 & -- \\
\hline & $25 \ldots$ & $19: 00$ & .091 & -- & 0.059 & 9 & $11 \ldots$ & $23: 00$ & .045 & -- & 0.052 & 3 \\
\hline & $25 \ldots$ & $22: 00$ & .099 & -- & 0.06 & 10 & $12 \ldots$ & $01: 00$ & .045 & -- & 0.054 & -- \\
\hline & $26 \ldots$ & $01: 00$ & .108 & -- & 0.076 & 14 & $12 \ldots$ & $03: 00$ & .045 & -- & 0.052 & 3 \\
\hline & $26 \ldots$ & $04: 00$ & .110 & -- & 0.076 & 8 & $12 \ldots$ & $05: 00$ & .045 & -- & 0.052 & 8 \\
\hline & $26 \ldots$ & $07: 00$ & .125 & -- & 0.12 & 8 & $12 \ldots$ & $07: 00$ & .045 & -- & 0.054 & 0 \\
\hline & $26 \ldots$ & $10: 00$ & .125 & -- & 0.10 & 7 & $12 \ldots$ & $09: 00$ & .045 & -- & 0.056 & -- \\
\hline & $26 \ldots$ & $13: 00$ & .125 & -- & 0.092 & 7 & $12 \ldots$ & $11: 00$ & .045 & -- & 0.054 & 24 \\
\hline & $26 \ldots$ & $16: 20$ & .125 & 0.07 & -- & 7 & $16 \ldots$ & $15: 00$ & .028 & 0.066 & -- & -- \\
\hline & $27 \ldots$ & $10: 15$ & .176 & 0.058 & -- & 6 & Aug 1984 & & & & & \\
\hline & $27 \ldots$ & $10: 30$ & .176 & -- & 0.061 & 6 & $20 \ldots$ & $12: 00$ & .024 & 0.110 & -- & -- \\
\hline & $27 \ldots$ & $14: 30$ & .170 & -- & 0.056 & 0 & $22 \ldots$ & $12: 00$ & .006 & 0.057 & -- & -- \\
\hline & $28 \ldots$ & $02: 30$ & .147 & -- & 0.046 & 3 & Jan 1986 & & & & & \\
\hline \multirow[t]{13}{*}{$\mathrm{Jul}$} & 1984 & & & & & & $27 \ldots$ & $06: 30$ & 1.42 & 0.12 & -- & -- \\
\hline & $03 \ldots$ & $11: 00$ & .042 & 0.059 & -- & -- & $27 \ldots$ & $08: 00$ & 1.50 & 0.13 & -- & -- \\
\hline & $05 \ldots$ & $18: 00$ & .037 & -- & 0.059 & 8 & $27 \ldots$ & $08: 30$ & 1.53 & 0.14 & -- & -- \\
\hline & $05 \ldots$ & $21: 00$ & .037 & -- & 0.057 & -- & $27 \ldots$ & $09: 30$ & 1.67 & 0.18 & -- & -- \\
\hline & $05 \ldots$ & $24: 00$ & .040 & -- & 0.056 & 7 & $27 \ldots$ & $10: 30$ & 1.70 & 0.21 & -- & -- \\
\hline & $06 \ldots$ & $03: 00$ & .042 & -- & 0.055 & -- & $27 \ldots$ & $11: 45$ & 1.73 & 0.16 & -- & -- \\
\hline & $06 \ldots$ & $06: 00$ & .042 & -- & 0.058 & 8 & $27 \ldots$ & $13: 30$ & 1.73 & 0.14 & -- & -- \\
\hline & $06 \ldots$ & $09: 00$ & .065 & -- & 0.084 & -- & $27, \ldots$ & $14: 30$ & 1.64 & 0.11 & -- & -- \\
\hline & $06 \ldots$ & $12: 00$ & .059 & -- & 0.059 & 7 & $27 \ldots$ & $15: 30$ & 1.61 & 0.10 & -- & -- \\
\hline & $06 \ldots$ & $15: 00$ & .057 & -- & 0.058 & -- & $27 \ldots$ & $16: 30$ & 1.59 & 0.092 & -- & -- \\
\hline & $06 \ldots$ & $18: 00$ & .051 & -- & 0.057 & 5 & $28 \ldots$ & $08: 00$ & 1.47 & 0.044 & -- & -- \\
\hline & $07 \ldots$ & $08: 45$ & .048 & 0.057 & -- & 4 & $28 \ldots$ & $13: 15$ & 1.47 & 0.038 & -- & -- \\
\hline & $07 \ldots$ & $09: 00$ & .048 & -- & 0.06 & 5 & $29 \ldots$ & $11: 30$ & 1.16 & 0.032 & -- & -- \\
\hline
\end{tabular}

1 EWI-ETR, equal width interval-equal transit rate sample collection method (Guy and Norman, 1970). 
Table 7.--Phosphorus glelds from Johnson Brook at South Albion, Maine, 1980-84 water years

1980 Water Year

Phosphorus yields, in Kilograms. for the year ending Septamber 30, 1980

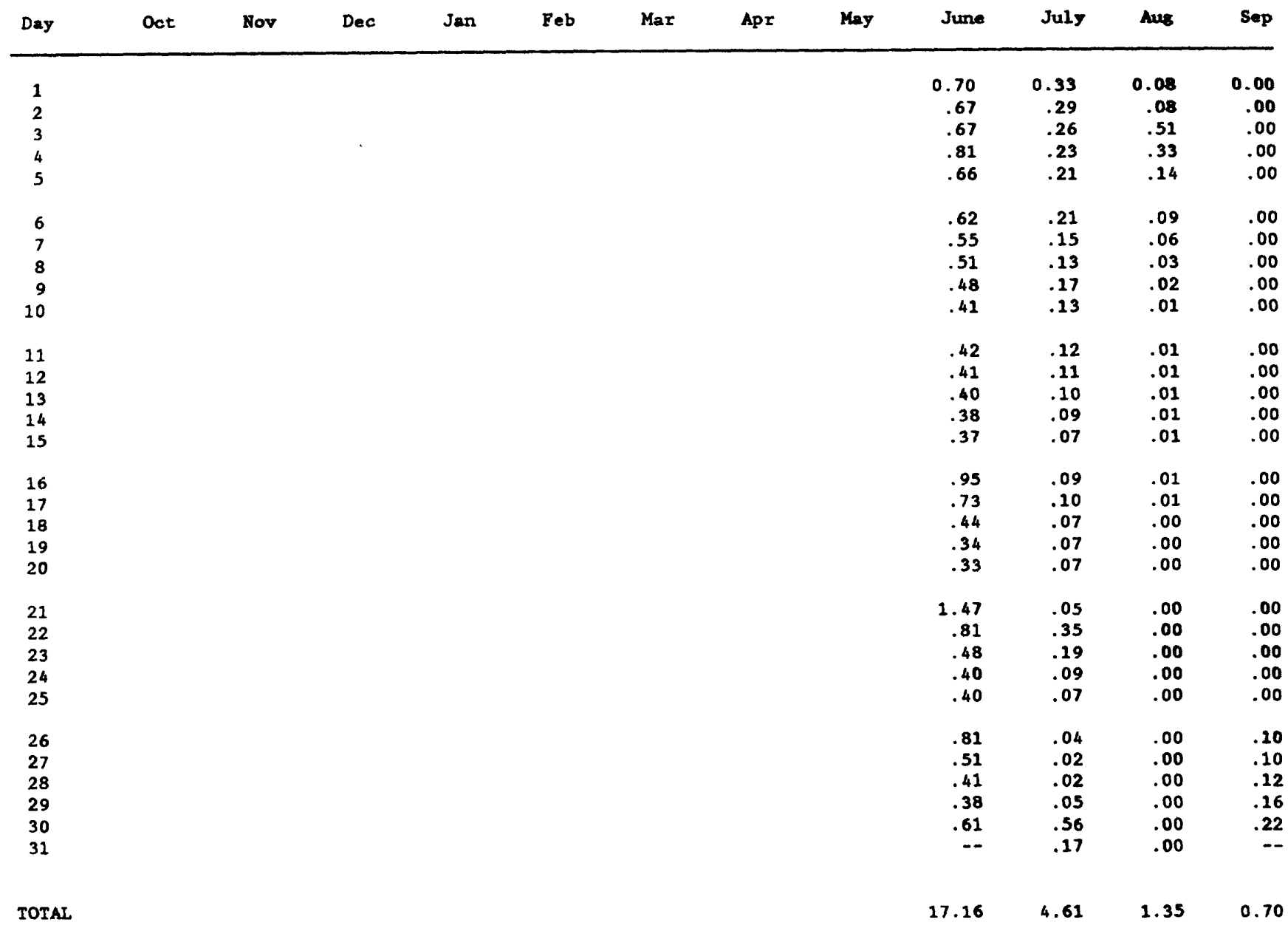


Table 7.--Phosphorus yields from Johnson Brook at South Albion, Maine, 1980-84 water years (continued)

1981 Water Year

Phosphorus yields, in K1lograms, for the year ending September 30, 1981

\begin{tabular}{|c|c|c|c|c|c|c|c|c|c|c|c|c|}
\hline Day & Oct & Nov & Dec & Jan & Feb & Mar & Apr & May & June & July & Aus & Sep \\
\hline 1 & 0.24 & 0.96 & 6.97 & 0.29 & 0.20 & 0.71 & 0.60 & 0.62 & 0.38 & 0.48 & 0.62 & 0.11 \\
\hline 2 & .26 & .83 & 5.47 & .27 & 87.84 & .61 & 4.13 & .59 & .32 & .39 & .53 & .10 \\
\hline 3 & .28 & .84 & 5.09 & .34 & 23.04 & .46 & .89 & .54 & .25 & .34 & .51 & .08 \\
\hline 4 & 3.7 & .75 & 4.10 & .33 & 3.30 & .35 & .94 & .48 & .23 & .27 & .39 & .08 \\
\hline 5 & 1.71 & .75 & 3.23 & .30 & 3.43 & .32 & 1.01 & .45 & .22 & .62 & .37 & .08 \\
\hline 6 & 1.28 & .70 & 2.50 & .29 & 2.58 & .30 & 1.27 & .44 & .20 & .79 & .33 & .07 \\
\hline 7 & 1.97 & .62 & 1.93 & .27 & 1.95 & .31 & 1.20 & .40 & .22 & .42 & .31 & .08 \\
\hline 8 & 2.04 & .62 & 1.44 & .26 & 1.40 & .29 & 1.17 & .39 & .16 & .34 & .26 & .07 \\
\hline 9 & 1.92 & .62 & 1.19 & .24 & .96 & .29 & .98 & .38 & .55 & .27 & .23 & .13 \\
\hline 10 & 1.46 & .59 & 1.02 & .22 & .61 & .28 & .93 & .39 & .32 & .22 & .22 & .10 \\
\hline 11 & 1.86 & .63 & .77 & .21 & 35.3 & .26 & .75 & .37 & .22 & .19 & .20 & .09 \\
\hline 12 & 7.27 & .59 & .51 & .19 & 15.9 & .24 & .66 & .37 & .21 & .16 & .16 & .08 \\
\hline 13 & 2.99 & .59 & .37 & .18 & 5.93 & .23 & .51 & 1.7 & .18 & .16 & .15 & .08 \\
\hline 14 & 1.78 & .59 & .34 & .17 & 4.3 & .23 & .81 & .58 & .17 & .19 & .13 & .07 \\
\hline 15 & 1.21 & .66 & .25 & .15 & 2.6 & .19 & .47 & .73 & .16 & .16 & .58 & .06 \\
\hline 16 & .99 & .92 & .07 & .15 & 1.8 & .20 & .27 & 3.23 & .32 & .13 & 5.75 & .06 \\
\hline 17 & 1.08 & 1.14 & .15 & .14 & 1.3 & .16 & .26 & 1.88 & .22 & .11 & 1.03 & .04 \\
\hline 18 & 1.58 & 1.40 & .13 & .13 & 1.0 & .16 & .31 & 1.08 & .15 & .11 & .78 & .04 \\
\hline 19 & 2.00 & 1.72 & .12 & .12 & .95 & .14 & .31 & 1.10 & .09 & .10 & .50 & .06 \\
\hline 20 & 1.13 & 2.00 & .31 & .10 & .88 & .13 & .30 & .90 & .12 & .06 & .43 & .07 \\
\hline 21 & 1.07 & 2.23 & 1.47 & .10 & .94 & .13 & .31 & .56 & 2.96 & 6.75 & .39 & .05 \\
\hline 22 & .832 & 2.67 & 1.13 & .09 & .88 & .12 & .33 & .48 & 4.23 & 4.40 & .33 & .17 \\
\hline 23 & .582 & 1.50 & .83 & .09 & .67 & .11 & .33 & .41 & 2.32 & 1.78 & .26 & .37 \\
\hline 24 & .392 & 1.47 & .70 & .08 & .59 & .10 & .36 & .40 & 1.35 & 1.01 & .19 & .78 \\
\hline 25 & 4.83 & 21.0 & .57 & .06 & .54 & .10 & .36 & .37 & 1.00 & .84 & .16 & .42 \\
\hline 26 & 26.30 & 8.90 & .56 & .06 & .64 & .10 & .34 & .33 & 1.93 & .64 & .15 & .16 \\
\hline 27 & 2.93 & 4.99 & .47 & .05 & .95 & .12 & .32 & .35 & .94 & .75 & .15 & .16 \\
\hline 28 & .859 & 8.99 & .44 & .02 & .75 & .17 & .29 & .32 & .78 & .59 & .12 & .27 \\
\hline 29 & 1.42 & 47.6 & .40 & .10 & -- & .20 & .36 & .29 & .66 & .99 & .11 & .17 \\
\hline 30 & 1.71 & 12.47 & .36 & .12 & -- & .23 & .69 & .32 & .51 & .83 & .11 & .16 \\
\hline 31 & 2.23 & - & .32 & .16 & -- & .30 & - & .43 & -- & .77 & .11 & - \\
\hline TOTAL & 79.88 & 129.3 & 43.21 & 6.35 & 203.47 & 7.64 & 21.46 & 20.85 & 21.87 & 24.87 & 15.56 & 4.26 \\
\hline
\end{tabular}


Phosphorus yields, In K1lograms, for the year ending September 30, 1982

\begin{tabular}{|c|c|c|c|c|c|c|c|c|c|c|c|c|}
\hline Day & Oct & Nov & Dec & Jan & Feb & Mar & Apr & May & June & July & Aus & Sep \\
\hline 1 & 0.13 & 1.87 & 0.26 & 0.16 & 0.13 & -- & 17.00 & 0.53 & 0.10 & 0.44 & 0.05 & 0.03 \\
\hline 2 & .11 & 1.54 & 3.35 & .16 & .13 & -- & 6.33 & .46 & 9.47 & .35 & .05 & .04 \\
\hline 3 & .09 & 1.13 & .99 & .16 & .13 & -- & 4.48 & .41 & 1.83 & .31 & .05 & .04 \\
\hline 4 & .07 & .73 & .88 & .82 & .13 & -- & 7.91 & .37 & .95 & .23 & .04 & .03 \\
\hline 5 & .08 & .56 & .69 & 12.23 & .13 & -- & 2.91 & .32 & .66 & .22 & .05 & .03 \\
\hline 6 & .08 & 1.37 & .56 & 4.60 & .13 & 0.13 & 2.06 & .28 & .54 & .20 & .05 & .03 \\
\hline 7 & .08 & .76 & .59 & .74 & .13 & .24 & 3.77 & .26 & .44 & .16 & .04 & .02 \\
\hline 8 & .12 & .67 & .47 & .62 & .13 & 1.43 & 2.09 & .24 & .35 & .14 & .06 & .02 \\
\hline 9 & .11 & .62 & .53 & .54 & .13 & .44 & 1.57 & .22 & .35 & .11 & .42 & .02 \\
\hline 10 & .11 & .55 & .47 & .47 & .13 & .42 & 1.37 & .22 & .28 & .10 & .31 & .02 \\
\hline 11 & .12 & .49 & .42 & .13 & .13 & .57 & 1.43 & .22 & .26 & .08 & .16 & .02 \\
\hline 12 & .13 & .39 & .38 & .13 & .13 & 2.11 & 1.20 & .22 & .23 & .06 & .12 & .02 \\
\hline 13 & .14 & .35 & .35 & .13 & .13 & 2.11 & 1.20 & .20 & .21 & .07 & .12 & .01 \\
\hline 14 & .15 & .29 & .29 & .13 & .13 & 2.38 & 1.98 & .19 & .18 & .06 & .10 & .01 \\
\hline 15 & .16 & .26 & .29 & .13 & .13 & 1.99 & 2.08 & .18 & .18 & .05 & .10 & .02 \\
\hline 16 & .16 & .27 & .39 & .13 & .13 & 1.72 & 2.20 & .17 & .18 & .05 & .08 & .02 \\
\hline 17 & .17 & .38 & .42 & .13 & .13 & 1.68 & 2.06 & .16 & .17 & .05 & .07 & .01 \\
\hline 18 & .88 & 2.83 & .37 & .13 & .13 & 1.89 & 2.45 & .15 & .18 & .04 & .07 & .01 \\
\hline 19 & 14.70 & 1.30 & .34 & .13 & .13 & 2.48 & 2.25 & .14 & .16 & .04 & .05 & .01 \\
\hline 20 & 3.17 & 1.13 & .30 & .13 & .13 & 2.15 & 2.06 & .82 & .16 & .06 & .05 & .01 \\
\hline 21 & 1.19 & 2.96 & .27 & .13 & .13 & 2.07 & 2.06 & .72 & .14 & .07 & .05 & .02 \\
\hline 22 & .79 & .71 & .26 & .13 & .13 & 1.47 & 1.86 & .22 & .12 & .06 & .05 & .04 \\
\hline 23 & 1.21 & .65 & .24 & .13 & .13 & 1.17 & 1.57 & .21 & .11 & .06 & .04 & .03 \\
\hline 24 & 11.60 & .54 & .23 & .13 & .13 & 1.08 & 1.27 & .19 & .11 & .05 & .09 & .02 \\
\hline 25 & 3.92 & .46 & .21 & .13 & .13 & 1.43 & 1.08 & .19 & .10 & .04 & .06 & .02 \\
\hline 26 & 2.91 & .39 & .21 & .13 & .13 & 6.07 & .90 & .16 & .11 & .04 & .07 & .02 \\
\hline 27 & 13.40 & .34 & .20 & .13 & .13 & 5.35 & .88 & .14 & .10 & .03 & .05 & .03 \\
\hline 28 & 7.83 & .34 & .19 & .13 & .13 & 3.94 & .79 & .12 & .09 & .08 & .04 & .04 \\
\hline 29 & 4.40 & .32 & .18 & .13 & -- & 3.66 & .69 & .10 & 1.20 & .18 & .03 & .03 \\
\hline 30 & 3.06 & .28 & .18 & .13 & -- & 3.19 & .59 & .10 & 1.22 & .07 & .03 & .03 \\
\hline 31 & 2.57 & -- & .17 & .13 & -- & 9.68 & -- & .10 & -- & .05 & .03 & -- \\
\hline TOTAL & 74.41 & 24.48 & 14.31 & 23.23 & 3.64 & 60.85 & 86.85 & 8.37 & 20.44 & 3.55 & 2.63 & 0.77 \\
\hline
\end{tabular}


Table 7.--Phosphorus yields from Johnson Brook at South Albion, Maine, 1980-84 water years (continued)

1983 Water Year

Phosphorus yields, in Kilograms, for the year ending September 30, 1983

\begin{tabular}{|c|c|c|c|c|c|c|c|c|c|c|c|c|}
\hline Day & Oct & Hov & Dec & Jan & Feb & Mar & Apr & May & June & July & Aus & Sep \\
\hline 1 & 0.02 & 0.03 & 0.12 & 0.34 & 0.17 & 0.10 & 0.49 & 1.54 & 1.59 & 0.04 & 0.01 & 0.01 \\
\hline 2 & .01 & .04 & .12 & .31 & .15 & 7.02 & .45 & 1.71 & 1.47 & .04 & .01 & .00 \\
\hline 3 & .01 & .04 & .12 & .26 & 25.50 & 6.18 & .40 & 1.96 & 1.42 & .04 & .01 & .00 \\
\hline 4 & .01 & .03 & .13 & .23 & 8.44 & 1.76 & 1.09 & 1.76 & 1.14 & .05 & .01 & .00 \\
\hline 5 & .01 & .20 & .12 & .18 & 1.47 & 1.17 & .57 & 2.08 & .86 & .05 & .01 & .00 \\
\hline 6 & .01 & .09 & .13 & .18 & .88 & 1.08 & .53 & 2.02 & .77 & .11 & .01 & .00 \\
\hline 7 & .02 & .06 & .14 & .18 & .53 & .95 & .51 & 2.06 & .69 & .08 & .01 & .00 \\
\hline 8 & .03 & .05 & .13 & .17 & .41 & 1.05 & .49 & 1.76 & .63 & .06 & .01 & .00 \\
\hline 9 & .02 & .04 & .12 & .15 & .33 & 1.12 & .48 & 1.47 & .52 & .05 & .01 & .00 \\
\hline 10 & .02 & .03 & .11 & .12 & .28 & 5.70 & .46 & 1.08 & .42 & .05 & .00 & .00 \\
\hline 11 & .02 & .02 & .07 & 15.73 & .24 & 4.39 & 3.56 & .98 & .42 & .04 & .00 & .00 \\
\hline 12 & .02 & .02 & .05 & 1.62 & .22 & 13.70 & 1.10 & .88 & .33 & .04 & .09 & .00 \\
\hline 13 & .02 & 2.66 & .03 & .99 & .19 & 5.87 & .80 & 1.15 & .28 & .09 & .06 & .00 \\
\hline 14 & .04 & .88 & .03 & .75 & .18 & 3.18 & .67 & .87 & .26 & .06 & .03 & .00 \\
\hline 15 & .03 & .80 & .03 & .63 & .17 & 1.54 & .61 & .89 & .22 & .05 & .02 & .00 \\
\hline 16 & .03 & .55 & 1.52 & .46 & .13 & 1.47 & .66 & .79 & .20 & .04 & .02 & .00 \\
\hline 17 & .02 & .33 & 1.01 & .40 & .12 & 1.32 & 12.20 & .65 & .18 & .03 & .01 & .00 \\
\hline 18 & .02 & .37 & .28 & .35 & .12 & 1.76 & 3.76 & .56 & .19 & .03 & .01 & .00 \\
\hline 19 & .02 & .27 & .19 & .30 & .12 & 3.75 & 2.58 & .46 & .19 & .03 & .00 & .00 \\
\hline 20 & .02 & .26 & .20 & .28 & .12 & 3.67 & 2.02 & .75 & .16 & .03 & .00 & .00 \\
\hline 21 & .02 & .23 & .21 & .24 & .11 & 4.07 & 1.57 & .88 & .13 & .02 & .00 & .00 \\
\hline 22 & .03 & .19 & .21 & .23 & .10 & 7.67 & 1.25 & .79 & .12 & .05 & .00 & .03 \\
\hline 23 & .02 & .18 & .17 & .23 & .12 & 3.13 & 1.03 & .90 & .09 & .05 & .00 & .06 \\
\hline 24 & .02 & .19 & .15 & 2.74 & .12 & 1.84 & 17.69 & .61 & .08 & .03 & .00 & .00 \\
\hline 25 & .02 & .19 & .16 & .95 & .12 & 1.32 & 41.67 & .41 & .07 & .03 & .00 & .00 \\
\hline 26 & .02 & .17 & 3.20 & .34 & .11 & 1.03 & 9.54 & .37 & .06 & .03 & .00 & .00 \\
\hline 27 & .02 & .16 & .49 & .25 & .10 & .88 & 4.33 & .66 & .06 & .02 & .00 & .00 \\
\hline 28 & .02 & .14 & .81 & .23 & .10 & 1.76 & 3.01 & 1.53 & .06 & .02 & .00 & .00 \\
\hline 29 & .03 & .15 & .71 & .21 & -- & .81 & 2.20 & .79 & .05 & .02 & .00 & .00 \\
\hline 30 & .01 & .18 & .48 & .20 & -- & .60 & 1.76 & 1.75 & .05 & .02 & .00 & .00 \\
\hline 31 & .03 & -- & .39 & .21 & -- & .44 & -- & 2.55 & -- & .01 & .01 & -- \\
\hline
\end{tabular}

TOTAL.

0.64

8. 5

11.63

29.46

40.67

90.33

$117.68 \quad 36.66$

12.11

1. 31

0.34

0.10 
Table 7.--Phosphorus ylelds from Johnson Brook at South Albion, Maine, 1980-84 water gears (continued)

1984 Water Year

Phosphorus ylelds, in Kilograms, for the year ending September 30, 1984

\begin{tabular}{|c|c|c|c|c|c|c|c|c|c|c|c|c|}
\hline Day & Oct & Nov & Dec & Jan & Feb & Mar & Apr & May & June & July & Aus & Sep \\
\hline 1 & 0.00 & 0.00 & 1.10 & 0.32 & 0.09 & 0.34 & 1.48 & 0.31 & 10.13 & 0.29 & 0.02 & 0.01 \\
\hline 2 & .00 & .00 & .86 & .28 & .08 & .59 & 1.88 & .67 & 22.26 & .25 & .02 & .01 \\
\hline 3 & .00 & .00 & .67 & .26 & .11 & .49 & 2.15 & .79 & 6.56 & .21 & .01 & .01 \\
\hline 4 & .00 & .01 & .61 & .29 & 10.22 & .42 & 2.28 & 1.25 & 5.09 & .18 & .01 & .01 \\
\hline 5 & .00 & .92 & .57 & .23 & 1.73 & .33 & 10.04 & .74 & 3.81 & .18 & .01 & .01 \\
\hline 6 & .00 & 1.53 & .51 & .21 & .53 & .29 & 17.79 & .64 & 2.84 & .25 & .01 & .01 \\
\hline 7 & .00 & .55 & 11.82 & .21 & .38 & .26 & 5.30 & .61 & 2.45 & .29 & .02 & .00 \\
\hline 8 & .00 & .28 & 1.54 & .20 & .35 & .21 & 3.36 & .55 & 1.97 & .54 & .03 & .00 \\
\hline 9 & .00 & .18 & 1.24 & .17 & .28 & .18 & 2.26 & .64 & 6.04 & .36 & .02 & .00 \\
\hline 10 & .00 & .12 & 1.02 & .15 & .25 & .16 & 1.71 & .59 & 1.27 & .29 & .01 & .00 \\
\hline 11 & .00 & 1.18 & .80 & .14 & .29 & .14 & 1.46 & .23 & .83 & .25 & .02 & .04 \\
\hline 12 & .00 & .96 & .76 & .12 & 2.53 & .12 & 1.32 & 4.03 & .56 & .22 & .02 & .22 \\
\hline 13 & .37 & .46 & 18.11 & .11 & 1.09 & .11 & 1.16 & 1.51 & .41 & .19 & .01 & .04 \\
\hline 14 & .12 & .18 & 13.64 & .10 & .61 & .06 & 1.14 & 2.82 & .33 & .17 & .02 & .03 \\
\hline 15 & .02 & .15 & 4.62 & .10 & 16.56 & .06 & .79 & 1.76 & 2.16 & .16 & .02 & .03 \\
\hline 16 & .01 & 3.51 & 3.30 & .10 & 3.18 & .26 & 1.39 & 1.54 & .61 & .15 & .01 & .03 \\
\hline 17 & .00 & 2.91 & 2.49 & .09 & 1.41 & 19.40 & 1.41 & 1.32 & .37 & .13 & .01 & .02 \\
\hline 18 & .00 & .59 & 1.90 & .09 & 1.16 & .73 & .95 & 1.22 & .22 & .12 & .01 & .02 \\
\hline 19 & .00 & .56 & 1.16 & .09 & .98 & 1.24 & 1.14 & 1.17 & .27 & .12 & .01 & .01 \\
\hline 20 & .00 & .49 & .79 & .09 & 1.65 & 3.02 & 1.24 & 1.02 & .17 & .09 & .22 & .01 \\
\hline 21 & .00 & 7.20 & .61 & .09 & .86 & 1.94 & 1.03 & .89 & .16 & .07 & .10 & .01 \\
\hline 22 & .00 & 2.45 & .51 & .08 & .73 & 5.90 & .81 & .67 & .15 & .06 & .03 & .01 \\
\hline 23 & .00 & .86 & .44 & .08 & .15 & 1.55 & .59 & .44 & .15 & .05 & .03 & .01 \\
\hline 24 & .00 & .84 & .37 & 2.51 & 4.52 & 1.45 & .83 & .43 & .13 & .05 & .07 & .01 \\
\hline 25 & .01 & 36.10 & .29 & 5.09 & 1.23 & 1.27 & .92 & .32 & .30 & .04 & .04 & .01 \\
\hline 26 & .00 & 7.00 & .26 & .25 & 8. 98 & 1.08 & .73 & .21 & .58 & .03 & .02 & .01 \\
\hline 27 & .00 & 3.43 & .23 & .16 & 1.54 & .88 & .61 & .22 & .88 & .03 & .01 & .01 \\
\hline 28 & .00 & 1.90 & .77 & .14 & 1.04 & .73 & .70 & .15 & .53 & .05 & .01 & .01 \\
\hline 29 & .00 & 3.05 & 4.82 & .11 & .98 & .64 & .66 & 4.09 & .38 & .04 & .01 & .01 \\
\hline 30 & .00 & 2.58 & .42 & .10 & -- & .54 & .59 & 3.86 & .29 & .03 & .01 & .00 \\
\hline 31 & .00 & - & .36 & .09 & -- & .49 & - & 21.46 & - & .03 & .01 & .00 \\
\hline TOTAL & 0.53 & 79.99 & 76.59 & 11.99 & 63.51 & 44.90 & 67.72 & 56.35 & 71.90 & 4.92 & 0.85 & 0.59 \\
\hline
\end{tabular}




\section{REFERENCES}

Elvin, C. E., and Hunt, G. S., 1985. Method for analysis of orthophosphate and total phosphorus: Department of Environmental Protection, Augusta, Maine, $3 \mathrm{p}$.

Fenneman, N. M., 1938, Physiography of the eastern United States: New York, McGraw-Hill Book Co., 714 p.

Guy, H. P., 1969, Laboratory theory and methods for sediment analysis: U.S. Geological Survey Techniques of Water-Resouces Investigations, book 5 , chap. $\mathrm{Cl}, 58 \mathrm{p}$.

Guy, H. P., and Norman, V. W., 1970, Field methods for measurement of fluvial sediment: U.S. Geological Survey Techniques of Water-Resources Investigations, book 3 , chap. $\mathrm{C} 2,59 \mathrm{p}$.

Hammer, M. J., and Mackichan, K. A., 1981, Hydrology and quality of water resources: New York, John Wiley and Sons, 486 p.

Knox, C. E., and Nordenson, T. J., 1955, Average annual runoff and precipitation in the New England-New York area: U.S. Geological Survey Hydrologic Investigations Atlas HA-7, 6 p., scale 1:1,000,000.

Lietman, P. L., Ward, J. R., Behrendt, T. E., 1983, Effects of specific land uses on non-point sources of suspended sediment, nutrients, and herbicides, Pequea Creek Basin, Pennsylvania 1979-80: U.S. Geological Survey Water-Resources Investigations Report 83-4113, 88 p.

Maloney, T. J., Dominie, D. R., II, and Nichols, W. J., Jr., 1983, Hydrologic data from the Johnson Brook phosphorus loading study, Kennebec County, Maine, March 1980 through September 1981: U.S. Geological Survey OpenFile Report 83-143, 24 p.

Minitab, Inc., 1985, Minitab reference manual, Minitab release 5.1: State College, Penna., Minitab Inc., 232 p.

Porter, K. S., ed., 1975, Nitrogen and phosphorus: food production, waste and the environment: Ann Arbor Science Publishers, Inc., 372 p.

Porterfield, George, 1972, Computation of fluvial-sediment discharge: U.S. Geological Survey Techniques of Water-Resources Investigations, book 3 , chap. $\mathrm{C} 3,66 \mathrm{p}$.

Rantz, S. E., and others, 1982, Measurement and computation of streamflow: vol. 1 and 2, Measurement of stage and discharge: U.S. Geological Survey Water-Supply Paper 2175, 631 p.

Skougstad, M. W., Fishman, M. J., Friedman, L. C., Erdmann, D. E., and Duncan, S. S. eds., 1979, Methods for the determination of inorganic substances in water and fluvial sediments: U.S. Geological Survey Techniques of WaterResources Investigations, book 5, chap. Al, 626 p. 
Sowles, J. W., and Dominie, D. R., II, 1984, Lovejoy Pond water quality final report: Maine Department of Environmental Protection, Augusta, Maine, $46 \mathrm{p}$.

Thomas, R. B., and Eads, R. E., 1983, Contamination of successive samples in portable pumping systems: Water Resources Research, vol. 19, no. 2, p. $436-440$.

U.S. Environmental Protection Agency, 1977, Quality criteria for water:

U.S. Government Printing Office, 256 p.

U.S. Weather Bureau, 1961, Rainfall frequency atlas of the United States for durations from 30 minutes to 24 hours and return periods from 1 to 100 years: U.S. Weather Bureau Technical Paper no. 40, 115 p.

1964, Two- to ten-day precipitation for return periods of 2 to 100 years in the contiguous United States: U.S. Weather Bureau Technical Paper no. $49,29 \mathrm{p}$.

Vollenweider, R. A., 1976, Advances in defining critical loading levels for phosphorus in lake eutrophication. Memorie dell'Istituto Italiano di Idrobiologia 33:35. 